Aus der Klinik für Neurochirurgie

(Prof. Dr. med. V. Rohde)

der Medizinischen Fakultät der Universität Göttingen

\title{
Die Rolle von Arlts1 im Glioblastoma multiforme
}

\author{
INAUGURAL-DISSERTATION \\ zur Erlangung des Doktorgrades \\ der Medizinischen Fakultät der \\ Georg-August-Universität zu Göttingen
}

vorgelegt von

Katrin Ostmeier

aus

Werther (Westf.)

Göttingen 2019 
Dekan:

Betreuungsausschuss

Betreuer/in

Ko-Betreuer/in:

\section{Prüfungskommission}

Referent/in:

Ko-Referent/in:

Drittreferent/in:
Prof. Dr. rer. nat. H. K. Kroemer

Prof. Dr. med. V. Rohde

Prof. Dr. med. H. Siggelkow

Prof. Dr. med. V. Rohde

Prof. Dr. med. H. Siggelkow

Prof. Dr. hum. biol. M. Schön

Datum der mündlichen Prüfung: 15. 07. 2020 
Hiermit erkläre ich, die Dissertation mit dem Titel "Die Rolle von Arlts 1 im Glioblastoma multiforme" eigenständig angefertigt und keine anderen als die von mir angegebenen Quellen und Hilfsmittel verwendet zu haben.

Göttingen, den

(Unterschrift) 


\section{Inhaltsverzeichnis}

Abbildungsverzeichnis.................................................................................................IV

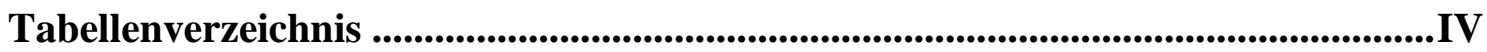

Abkürzungsverzeichnis ................................................................................................ V

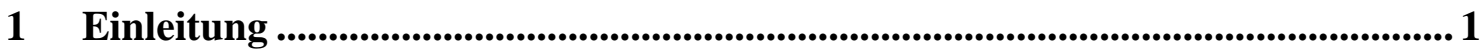

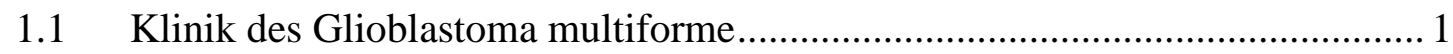

1.1.1 Ätiologie und Pathogenese des Glioblastoms ........................................ 2

1.1.2 Aktueller Stand der Therapie .............................................................. 3

1.2 ADP-ribosylation factor-like tumor suppressor 1 - Arlts 1 ................................ 4

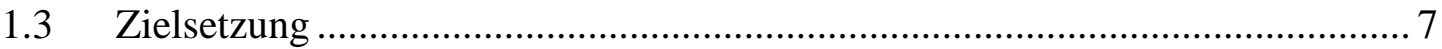

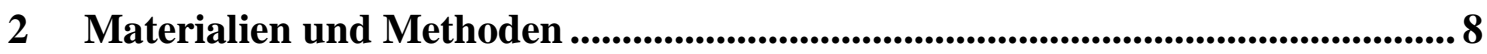

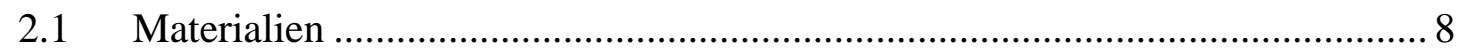

2.1.1 Laborgeräte und Verbrauchsmaterialien.............................................. 8

2.1.2 Chemikalien, Enzyme und Medien......................................................... 9

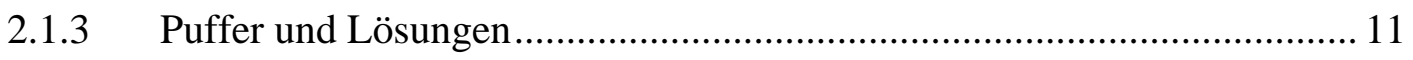

2.1.4 Reaktionskits................................................................................. 13

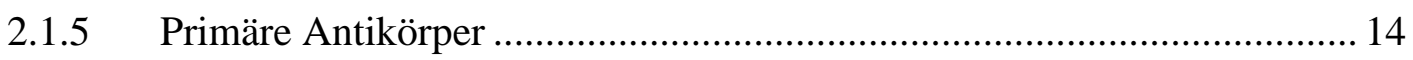

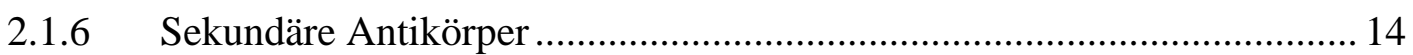

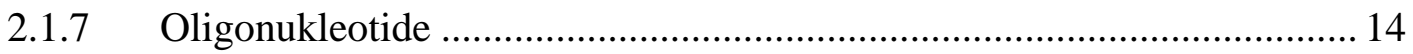

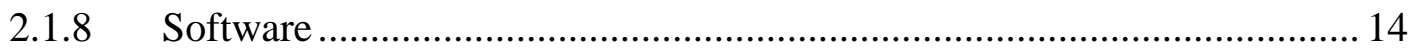

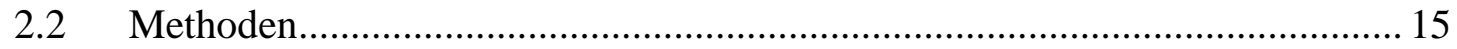

2.2.1 Klonierung von pEGFP-N1-Arlts1 ................................................... 15

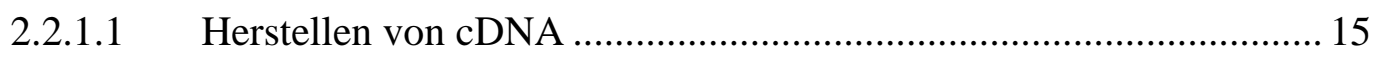

2.2.1.2 PCR für die Amplifikation von dem Insert ARLTS1 ....................... 15

2.2.1.3 Agarosegelelektrophorese und Extraktion aus dem Gel .................. 16

2.2.1.4 Restriktionsenzymverdau ........................................................... 16

2.2.1.5 Ligation von DNA-Fragmenten ................................................. 17

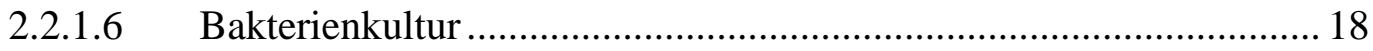

2.2.1.7 Transformation von kompetenten E. coli ......................................... 18

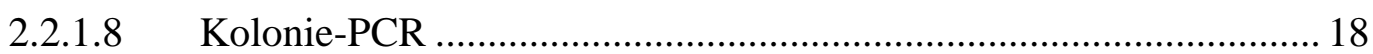

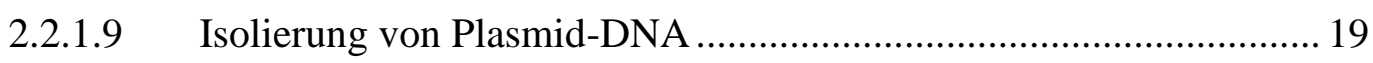

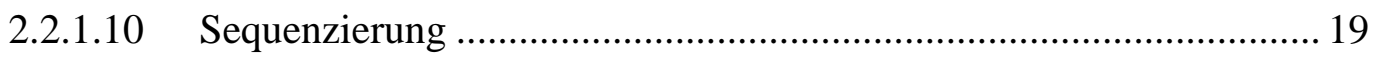

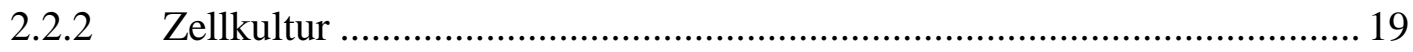

2.2.2.1 Zelllinie und deren Kultivierung …................................................. 19

2.2.2.2 Aussäen der Zellen ...................................................................... 20

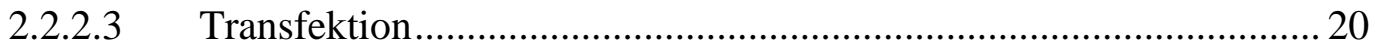

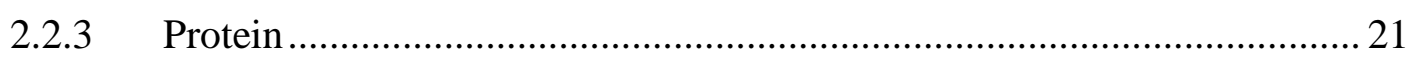

2.2.3.1 Proteinextraktion für die Western Blots .......................................... 21 
2.2.3.2 Proteinextraktion für die Zymographie ........................................ 22

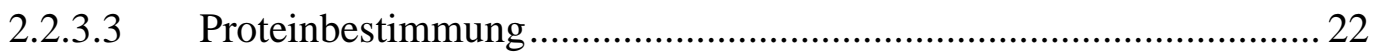

2.2.3.4 Polyacrylamid-Gelelektrophorese (SDS-Page) für Western Blots.... 23

2.2.3.5 Polyacrylamid-Gelelektrophorese (SDS-Page) für Zymographie..... 24

2.2.3.6 Western-Blot-Transfermethode ....................................................... 24

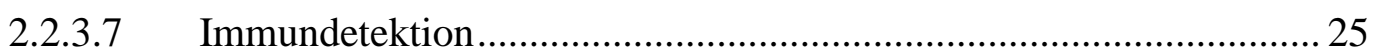

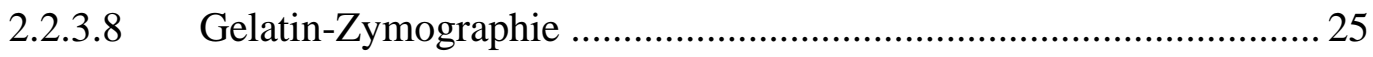

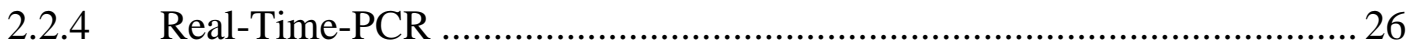

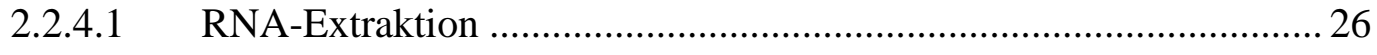

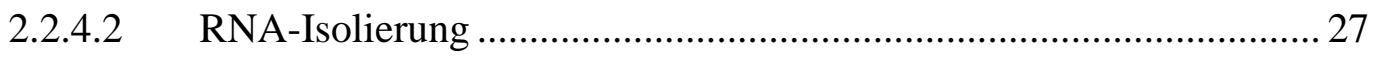

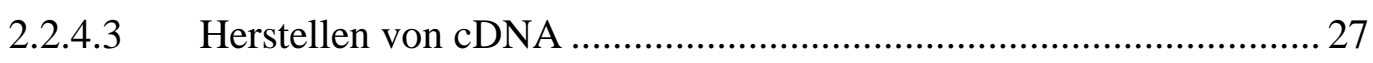

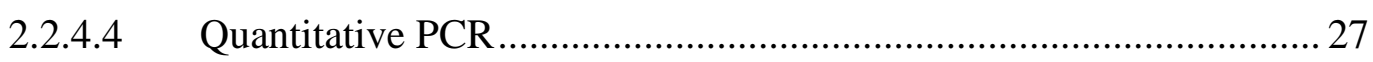

2.2.5 Färbung für konfokale Mikroskopie .................................................. 28

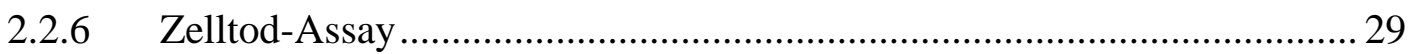

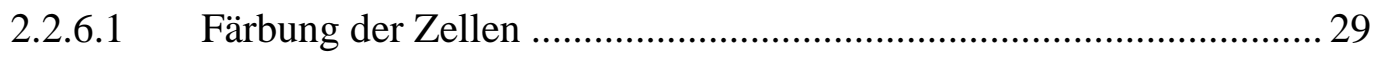

2.2.6.2 Durchflusszytometrie ............................................................... 29

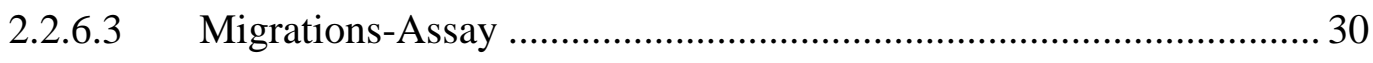

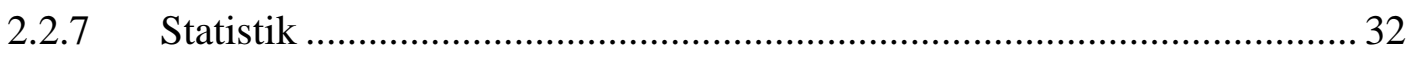

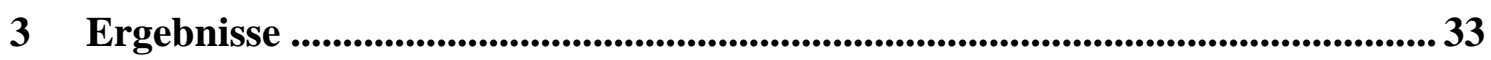

3.1 ARLTS1-mRNA wird durch CRABP2 stabilisiert ........................................ 33

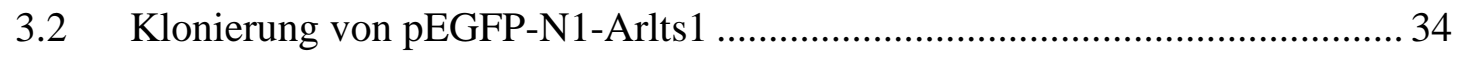

3.3 Expression von pEGFP-N1-Arlts1 in U87-MG-Zellen ................................. 35

3.4 Bestimmung der Transfektionseffizienz der U87-MG-Zellen mittels

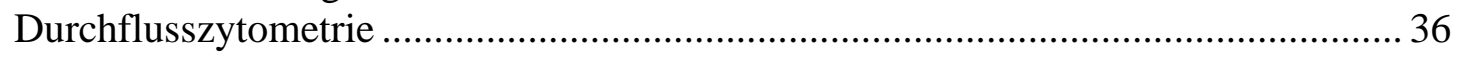

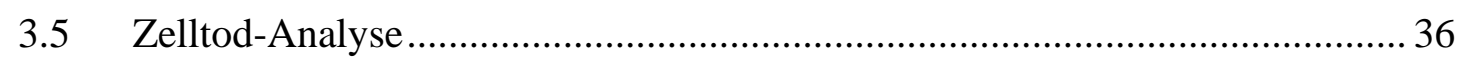

3.5.1 Bestimmung der mRNA-Expression proapoptotischer Gene in ARLTS1

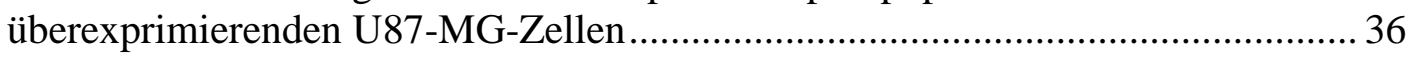

3.5.2 Zelltodanalyse von ARLTS1 überexprimierenden U87-MG-Zellen ......... 37

3.6 Analyse der mRNA-Expression von B-cell lymphoma 2 (BCL-2) in ARLTS1

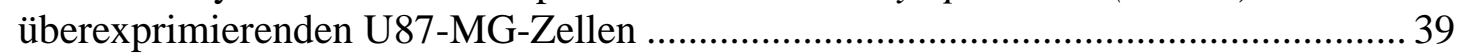

3.7 Untersuchung der Matrix-Metalloproteasen MMP2 und MMP9..................... 40

3.7.1 Verminderte mRNA Expression von MMP2 und MMP9 in ARLTS1 überexprimierenden U87-MG-Zellen................................................................ 40

3.7.2 Gelatin-Zymographie zur Überprüfung der aktivierten MMP2 und -9 .... 41

3.8 ARLTS1 hat keinen Einfluss auf das Migrationsverhalten der U87-MG-

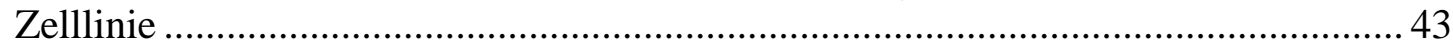

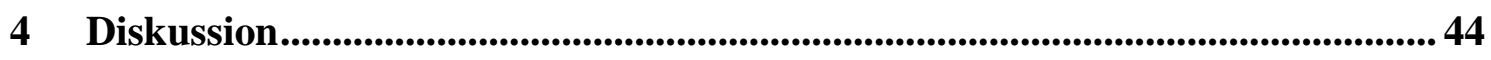

4.1 Der Zusammenhang von Arlts1 und CRABP2 ........................................... 44

4.2 U87-MG-Zellen transfiziert mit ARLTS1 zeigen keine verstärkte Apoptose .. 46 
4.3 Mögliche inhibitorische Effekte von Arlts1 in der Migration von

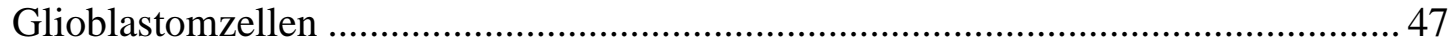

4.4 Kritische Betrachtung und Ausblick der Arbeit ............................................. 49

5 Zusammenfassung ....................................................................................................... 50

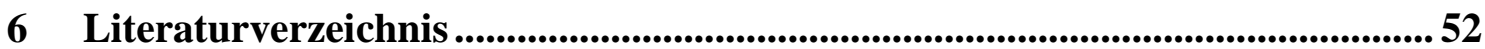




\section{Abbildungsverzeichnis}

Abb. 1: Schematischer Aufbau einer CIM-Plate 16

Abb. 2: Relative Expression von ARLTS1-mRNA in U87-MG-Zellen nach

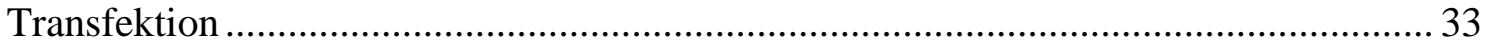

Abb. 3: Vektorkarte für das Plasmid pEGFP-N1-Arlts1 ….............................................. 34

Abb. 4: Kolonie-PCR zur Kontrolle der Transformation des Plasmids .......................... 35

Abb. 5: Konfokale Mikroskopie der transfizierten U87-MG-Zellen.............................. 35

Abb. 6: Ermittlung der Transfektionseffizienz mittels Durchflusszytometrie ............... 36

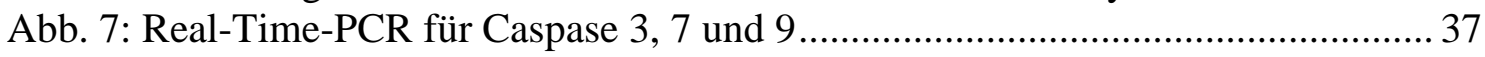

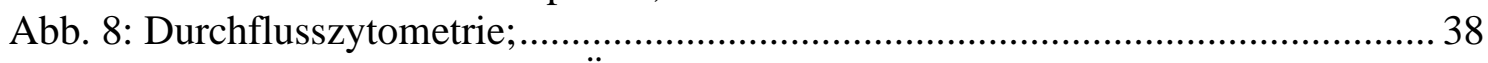

Abb. 9: Durchflusszytometrie zur Überprüfung von Nekrose/später Apoptose.............. 39

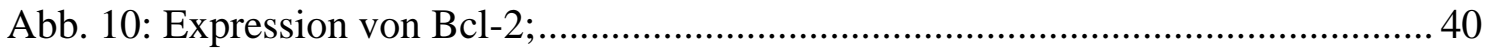

Abb. 11: Real-Time-PCR mit spezifischen Primern für $M M P 2$ und $M M P 9 \ldots \ldots \ldots \ldots \ldots . . . . .41$

Abb. 12: Gelatin-Zymographie für die Funktionalität von MMP2 und MMP9 …......... 42

Abb. 13: Migrationsassay $24 \mathrm{~h}$ nach Transfektion ....................................................... 43

Abb. 14: Hypothese über die Rolle von Arlts1 im Zusammenhang mit CRABP2 in der

Zelle

\section{Tabellenverzeichnis}

Tabelle 1: Pipettierschema für die Herstellung von cDNA-Ansatz I ............................. 15

Tabelle 2: Pipettierschema für die Herstellung von cDNA-Ansatz II ........................... 15

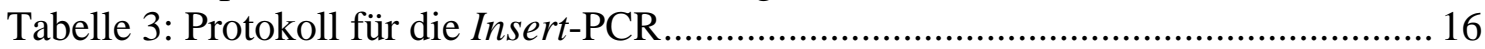

Tabelle 4: Pipettierschema für den Enzymverdau mit KpnI ....................................... 17

Tabelle 5: Pipettierschema für den Enzymverdau mit BamHI ..................................... 17

Tabelle 6: Pipettierschema für die Ligation von pEGFP-N1 und ARLTS1 ................... 17

Tabelle 7: Pipettierschema für eine Probe einer Kolonie-PCR ..................................... 19

Tabelle 8: Mengenangaben für das 12\%ige Trenngel aus Polyacrylamid....................... 23

Tabelle 9: Mengenangaben für das Sammelgel für den Western Blot .......................... 23

Tabelle 10: Mengenangaben für das 7,5\%ige Trenngel aus Polyacrylamid................... 24

Tabelle 11: Mengenangaben für das Sammelgel für die Zymographie ........................... 24

Tabelle 12: Pipettierschema der qPCR für eine Probe …............................................ 27

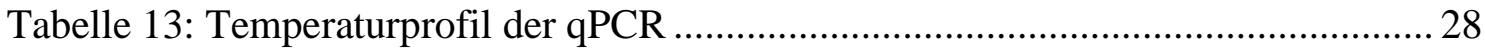




\section{Abkürzungsverzeichnis}

Apaf-1

APC

APS

ARL11

Arlts 1

Bcl-2

cDNA

CLL

CRABP2

DAPI

dATP

dCTP

dGTP

DNA

dNTP

dTTP

DTT

E. coli

EDTA

EGFP

EGFR

EGTA

FACS

FCS

FITC

$F w$

GBM

GFP

HMBS

HPRT1

HRP

HuR

IDH1 und 2

$\mathrm{kB}$

$\mathrm{kDa}$

LB-Medium

MAP

MCS

MDM2/ MDM4

MEM

MGMT

MMP

NEAA

ori

PBS

PCR

PDL

PTEN

RA apoptotic protease-activating factor-1

Allophycocyanin

Ammoniumperoxidsulfat

ADP-ribosylation factor-like GTPase 11

ADP-ribosylation factor-like tumor supressor 1

B-cell lymphoma 2

komplementäre Desoxyribonukleinsäure

chronisch lymphatische Leukämie

cellular retinoic acid-binding protein 2

4',6-diamidin-2-phenylinidol

Deoxyadenosintriphosphat

Deoxycytosintriphosphat

Deoxyguanosintriphosphat

Desoxyribonukleinsäure

Desoxyribonukleosidtriphosphat

Deoxythymidintriphosphat

Dithiotreitol

Escherichia coli

Ethylendiamintetraessigsäure

enhanced grün fluoreszierendes Protein

epidermal growth factor receptors

Ethylenglycol-bis(aminoethylether)-tetraessigsäure

fluorescence-activated cell sorting

fetal calf serum

fluorescein isothiocyanate

forward

Glioblastoma multiforme

grün fluoreszierendes Protein

Hydroxymethylbilan-Synthase

Hypoxanthin-Phosphoribosyl-Transferase 1

horseradish peroxidase

humanes Antigen R

Isocitrat-Dehydrogenase 1 und 2

Kilobasen

Kilodalton

lysogeny-broth-Medium

mitogen activated protein

multiple cloning site

mouse double minute 2/4 homologue

minimum essential medium

O6-Methylguanin-DNA-Methyltransferase

Matrix-Metalloprotease

non-essential amino acid

origin of replication

phosphate-buffered saline

Polymerase-Kettenreaktion

Poly-D-Lysin

phosphatase and tensin homolog

Retinsäure 
Rev

RFU

RNA

Rpm

SDS

TAE

TBS

TBST

TEMED

TGF- $\beta$

TP53

$V E G F$

$\mathrm{v} / \mathrm{v}$

$\mathrm{WHO}$

$\mathrm{w} / \mathrm{v}$ reverse

relative fluorescent units

Ribonukleinsäure

rounds per minute

sodium dodecyl sulfate

Tris-Acetat-EDTA

Tris-buffered saline

Tris-buffered saline with Tween 20

Tetramethylethylendiamin

transforming growth factor- $\beta$

Tumorsuppressorgen p53

vascular endothelial growth factor

Verhältnis Volumen zu Volumen

Weltgesundheitsorganisation

Verhältnis Gewicht zu Volumen 


\section{$1 \quad$ Einleitung}

\subsection{Klinik des Glioblastoma multiforme}

Das Glioblastoma multiforme (GBM) ist der häufigste und aggressivste primäre Tumor des zentralen Nervensystems bei Erwachsenen (Louis et al. 2007). Eine 5-Jahres-Überlebensrate von unter 5\% (Ostrom et al. 2014) verdeutlicht, dass die aktuell angewandten Therapieansätze bei diesem Tumor nur unzureichend wirken. Die Inzidenz in Europa beträgt 3 pro 100.000 Einwohner (Crocetti et al. 2012). Bei einer mittleren Überlebensdauer von 15 Monaten unter Therapie (Tran und Rosenthal 2010) bleibt der Tumor bis heute unheilbar. Unbehandelt führt das GBM innerhalb von drei Monaten zum Tod (Malmström et al. 2012). Weniger als fünf Prozent sogenannter Langzeitüberlebender lebt nach Diagnosestellung länger als fünf Jahre (Smoll et al. 2013). Anhand dieser Zahlen wird der Bedarf an intensiver Forschung deutlich, um die in vitro erworbenen Erkenntnisse in erfolgreiche Therapiekonzepte übersetzen zu können.

Je nach Lokalisation und Größe des Tumors zeigen sich sehr unterschiedlich ausgeprägte klinische Erscheinungen. Patienten mit einem neu diagnostizierten GBM zeigen häufig Symptome eines erhöhten intrakraniellen Hirndrucks, wie Kopfschmerzen, Übelkeit, Einschränkungen des Visus oder Müdigkeit. Die Raumforderung kann neurologische Defizite, wie z. B. Persönlichkeitsveränderungen, Hemiparesen oder Gedächtnisverlust verursachen (Young et al. 2015). Ein neu auftretender Krampfanfall ist dabei eines der häufigsten Erstsymptome (Schiff et al. 2015).

Nach den Kriterien der Weltgesundheitsorganisation (WHO) werden Gliome in vier Grade eingeteilt. Das Glioblastoma multiforme wird nach dieser Klassifikation aufgrund seiner hohen Malignität dem Grad IV zugeordnet. Der Begriff „Gliom“ ist als Oberbegriff $\mathrm{zu}$ verstehen und teilt sich in verschiedene Untereinheiten je nach Ursprungszelle auf. Seit vielen Jahren allerdings besteht Uneinigkeit darüber, welche Zellen ursprünglich für die Entstehung des GBMs verantwortlich sind. Es ist immer noch Gegenstand aktueller Untersuchungen, ob Astrozyten, andere Gliazellen oder Stammzellen einer genetischen Veränderung unterliegen und so zum Glioblastoma multiforme führen.

Mit einem Anteil von 60\% ist das Glioblastoma multiforme der häufigste hirneigene Tumor (Rock et al. 2012). Das pilozystische Astrozytom (Grad I) und das diffuse Astrozytom (Grad II) zeichnen sich durch ein langsames und weniger aggressives Wachstum aus. Allerdings sei erwähnt, dass bereits das diffuse Astrozytom (Grad II) - trotz eines operativen Eingriffes - eine hohe Rezidivrate aufweist, da das Wachstum zwar langsam, aber 
bereits infiltrativ verläuft. Das anaplastische Astrozytom (Grad III) und das Glioblastom sind durch Mitosefiguren, Zellatypien, Nekrosen und Gefäßproliferation charakterisiert (Louis et al. 2007).

Das Glioblastom ist eine maligne Erkrankung des höheren Alters. Zum Zeitpunkt der Diagnosestellung beträgt das durchschnittliche Alter 64 Jahre. Die Inzidenz ist mit fortschreitendem Alter zunehmend und hat ihren Höhepunkt in einer Altersspanne von 75 bis 84 Jahren. Bei Kindern und Jugendlichen zwischen 0-19 Jahren ist das GBM nur zu 3\% aller Tumoren des zentralen Nervensystems vertreten (Ohgaki et al. 2004). Studien zeigen, dass die schwarze Bevölkerung seltener an einem GBM erkrankt als die weiße (Iacob und Dinca 2009).

\subsection{1 Ätiologie und Pathogenese des Glioblastoms}

Glioblastome werden nach ihrer Genese und der jeweiligen genetischen Variabilität in primäre und sekundäre Tumoren eingeteilt. Die primären GBMs entstehen de novo und sind häufiger bei älteren Patienten zu finden. Die sekundären Glioblastome entwickeln sich entweder aus einem Astrozytom Grad II oder aus einem Grad III bei Patienten mit einem mittleren Alter von 45 Jahren. Die Inzidenzrate des primären GBMs ist bei Männern dreifach höher als bei Frauen ( $\mathrm{M}: \mathrm{F}=3: 1)$, während es beim sekundären GBM der umgekehrte Fall ist (Kleihues und Ohgaki 2000; Ohgaki et al. 2004; Ohgaki und Kleihues 2009).

Die Ätiologie dieses Tumors ist bislang weitgehend unbekannt. Die Literaturangaben zeigen heterogene Ergebnisse hinsichtlich der Entstehungsursachen. Eine hoch dosierte ionisierende Strahlung ist bislang - neben Polyvinylchlorid - der einzig gesicherte Faktor welcher die Entstehung eines GBMs begünstigt (Bondy et al. 2008). Rauchen, Ernährung oder die Benutzung von Mobiltelefonen haben hingegen keinen Einfluss (Inskip et al. 2001; Bondy et al. 2008). In der Regel sind Glioblastome sporadisch auftretende Tumoren. Allerdings ist ein gehäuftes Auftreten bei genetisch bedingten Krankheiten, wie dem Li-Fraumeni-Syndrom, Neurofibromatose 1 und 2, dem Von-Hippel-Lindau-Syndrom oder dem Turcot-Syndrom sowie Tuberöse Sklerose festgestellt worden (Iacob und Dinca 2009).

Nicht nur bezüglich der Ätiologie, sondern auch bezüglich der Pathogenese sind noch immer viele Fragen offen. Die Hypothese, ein Glioblastom entstehe aus einer Dedifferenzierung ausgereifter Gliazellen, wurde abgelöst durch die Vermutung, dass entweder eine 
Transformation neuronaler Stammzellen oder gliale Vorstufen zum Grad-IV-Glioblastom führen (Louis et al. 2007; Masui et al. 2012).

Fortschritte in der Molekularbiologie haben es ermöglicht, auch beim GBM diverse Mutationen zu identifizieren. Eine Punktmutation im Isocitrat-Dehydrogenase 1- und 2-Gen (IDHI und 2) wird als selektiver Marker zur Differenzierung von primären und sekundären GBMs verwendet. Sekundäre Glioblastome zeigen Mutationen in IDH1/2 auf (Yan et al. 2009). Gliome vom Grad IV mit einer Mutation in IDHI haben eine bessere Prognose als Gliome ohne diese Mutation (Hartmann et al. 2010).

Primäre Glioblastome zeigen außerdem häufig Amplifikationen des epidermal growth factor receptors (EGFR) auf, einen Verlust des langen Armes von Chromosom 10, Mutationen der Phosphatase PTEN (phosphatase and tensin homolog) und Mutationen des mouse double minute 2/4 homologue (MDM2/ MDM4) (Nakamura et al. 2001; Ohgaki und Kleihues 2007). Sekundäre Glioblastome sind in der Regel bei jüngeren Patienten zu finden und zeichnen sich unter anderem häufig durch eine Mutation des Tumorsuppressorgens p53 (TP53) aus (Ohgaki et al. 2004).

\subsubsection{Aktueller Stand der Therapie}

Bei der Wahl der Therapie sind neben dem Alter des Patienten auch der Karnofsky-Index und der Methylierungsstatus des Gens O6-Methylguanin-DNA-Transferase (MGMT) relevant. Von großer Bedeutung ist die Abwägung von Nutzen und Risiken, denn das GBM gilt bis heute als unheilbar. Der heutige Standard der Therapie sieht eine Resektion von $>98 \%$ des gesamten Tumors vor. Retrospektive Studien konnten eine Verdopplung des Überlebens mit Resektion im Vergleich zur alleinigen Biopsie zeigen (Lacroix et al. 2001). Unter Verwendung des fluoreszierenden Farbstoffes 5-Aminolävulinsäure (5-Ala) während der Operation konnte das Überleben um vier Monate verlängert werden $(\mathrm{Ng}$ et al. 2017). 5-Ala ist ein Prodrug von grün fluoreszierenden Porphyrinen und akkumuliert in der Tumorzelle stärker als in der gesunden Zelle (Stummer et al. 2006). Es hilft dem Operateur, zwischen gesundem und durch Tumor infiltriertem Gewebe zu differenzieren. Vorausgesetzt, die Wundheilung ist ausreichend fortgeschritten, beginnt zwei bis vier Wochen nach der Operation eine Radiotherapie mit 60 Gy über einen Zeitraum von sechs Wochen (Kristiansen et al. 1981). Trotz der langen Geschichte der Chemotherapie wird im Fall eines GBMs bis heute nur Temozolomid (TMZ) verwendet. Ein in Frage kommendes Chemotherapeutikum muss die Bluthirnschranke passieren können und wegen unerwünschter Nebenwirkungen für den Patienten zumutbar sein. Nach dem 
Therapieprotokoll von Stupp wird im Anschluss einer Operation TMZ begleitend zur Radiotherapie gegeben. Nach der Radiotherapie wird das Chemotherapeutikum für weitere sechs Monate alle vier Wochen für fünf Tage verabreicht (Stupp et al. 2009).

Der Methylierungsstatus des Promotors des Gens O6-Methylguanin-DNA-Transferase gibt Auskunft über die individuelle Prognose. Patienten mit methyliertem MGMT Promotor sprechen besser auf eine Chemotherapie mit Temozolomid an (Nakamura et al. 2001; Eoli et al. 2007). MGMT ist ein wichtiges Enzym der DNA-Reparatur. Es entfernt dabei alkylierende Gruppen von der O6-Position von Guanin. TMZ ist ein solches alkylierendes Chemotherapeutikum, dessen Wirkung verstärkt werden kann, wenn der MGMT Promotor methyliert und das Enzym inaktiv ist (Hegi et al. 2005). Aufgrund dieser Erkenntnis wird der Methylierungsstatus von MGMT routinemäßig zur Erstellung eines Therapieplans molekularbiologisch bestimmt und trägt mittlerweile sogar entscheidend zur Wahl der Therapie bei (Malmström et al. 2012).

Im derzeitigen Fokus der Therapieforschung zu GBM steht auch die sogenannte gezielte Krebstherapie (Targeted therapy) mit monoklonalen Antikörpern und sogenannten „small molecules“. Ein monoklonaler Antikörper gegen den vascular endothelial growth factor (VEGF), Bevacizumab, wird zum Beispiel bei rezidivierenden GBMs getestet (Nagpal et al. 2011).

Es sind bis heute allerdings keine Biomarker bekannt, die hilfreich für die Früherkennung eines GBMs sind. Da Hirntumore dieser Art meist erst in einem fortgeschrittenen Stadium diagnostiziert werden, könnte ein solcher Biomarker helfen, eine Therapie früher zu beginnen und den Verlauf der Therapie zu kontrollieren.

\subsection{ADP-ribosylation factor-like tumor suppressor 1 - Arlts1}

Arlts1 gehört zu der ADP-ribosylation factor ( $A R F)$-ARF-like (ARL) Familie. Diese wird der großen Familie der Ras-Proteine zugeordnet. Arlts1 steht für ADP-ribosylation factor like tumor suppressor 1. Das Gen wird auch als ARL11 (ADP-ribosylation factor-like GTPase 11) abgekürzt. ARLTS1 befindet sich auf Chromosom 13q14 und kodiert für ein 196 Aminosäuren $(21 \mathrm{kDa})$ großes Protein.

Die Familie der Arl-Proteine steht im Zusammenhang mit der Regulation des Transports von Vesikeln (Wennerberg et al. 2005). Die Proteine dieser großen Familie können je nach Aktivitätszustand zwischen GTP oder GDP wechseln. Nur im GTP-Zustand können sie weitere Signalproteine aktivieren. Es wurde gezeigt, dass ARLTS1 ubiquitär im 
humanen Gewebe exprimiert wird. Homologe von ARLTS1 sind im Zebrafisch, Drosophila, Arabidopsis und in Säugetieren zu finden (Yendamuri et al. 2007). Dies spricht für eine hohe Konservierung im Laufe der Evolution und lässt vermuten, dass das Protein eine wichtige Rolle im Organismus spielt. Die genaue Funktion ist allerdings bislang unbekannt.

Im Jahr 2005 beschrieben Calin et al. erstmals, dass bestimmte Polymorphismen in ARLTS1 mit familiär und sporadisch auftretenden Tumoren assoziieren. In 800 DNAProben von Patienten mit Tumoren konnte ein signifikanter Zusammenhang zur Mutation c. G446A (p. Trp149*) gezeigt werden. Des Weiteren wurden Tumorzellen eines nichtkleinzelligen Bronchialkarzinoms, transfiziert mit der Wildtyp-Variante von ARLTS1, in $\mathrm{Nu} / \mathrm{Nu}$ Nude-Mäuse injiziert. Die mit Wildtyp-ARLTS1 transfizierten Tiere zeigten eine deutliche Reduktion des Tumorgewichts. Somit wurde ARLTS1 erstmalig als Tumorsuppressorgen beschrieben (Calin et al. 2005). Tumorsuppressorgene sind Gene, deren Produkte, die Tumorsuppressoren, entweder an Signaltransduktionsketten oder direkt an Zellzyklus und Apoptose beteiligt sind. Sie hemmen das Wachstum von Zellen. Die Inaktivierung eines Tumorsuppressorgens, zum Beispiel durch Hypermethylierung des Promoters, würde das Wachstum von Tumorzellen und damit die Entstehung von Tumoren begünstigen (Herman 1999).

Es wird postuliert, dass für die Entstehung von sporadisch auftretenden Tumoren eine Hypermethylierung des Promotors von ARLTS1 oder ein Verlust der Heterozygotität verantwortlich ist. Die Ursache zur Entstehung von familiären Tumoren liegt hingegen eher in der Entwicklung von sogenannten Einzelnukleotid-Varianten in dem Gen (Yendamuri et al. 2007). Besonders die Missense-Mutation c. T442C (p. Cys148Arg) und NonsenseMutation c. G446A (p. Trp149*) zeigen die häufigsten Assoziationen mit der Entstehung von diversen Tumoren (Jiang et al. 2017).

Die Mutation c. T442C (p. Cys148Arg) in ARLTS1 wurde im malignen Melanom (Frank et al. 2006b), im Mammakarzinom, im Prostatakarzinom (Siltanen et al. 2008; Siltanen et al. 2011) und im Ovarialkarzinom (Yang et al. 2009) als Risikofaktor für die Entwicklung von Krebs beschrieben. Sowohl im familiären als auch im sporadisch auftretenden Kolorektalkarzinom wurde diese Einzelnukleotid-Variante als statistisch relevant beschrieben (Castellví-Bel et al. 2007). Im bilateralen Mammakarzinom (Frank et al. 2006a), im Kolorektalkarzinom (Frank et al. 2006c) und im Ovarialkarzinom (Petrocca 
et al. 2006) wurde ein Zusammenhang zwischen der Mutation c. G446A (p. Trp149*) in ARLTS1 und der Entstehung dieser Karzinome gezeigt.

In $37 \%$ der Biopsien aus verschiedenen Lungentumoren konnte eine stark reduzierte Expression von ARLTS1 gezeigt werden. Nachdem die Expression von ARLTS1 in unterschiedlichen Zelllinien durch Transfektion wiederhergestellt worden ist, konnte eine signifikant erhöhte Apoptoserate der Tumorzellen ermittelt werden (Yendamuri et al. 2007).

Ähnlich dazu wurde in Ovarialkarzinomzellen (SKOV3) eine signifikant erhöhte Sensitivität für Chemotherapeutika und eine erhöhte Apoptose durch die Überexpression von Wildtyp-ARLTS1 in vitro beschrieben (Yang et al. 2011).

Für das Prostatakarzinom wird vermutet, dass Arlts1 das Immunsystem beeinflusst. Siltanen et al. stellten im Jahr 2013 die Hypothese auf, dass es eine Interaktion zwischen ARLTS1 und diversen inflammatorischen Genen im Prostatakarzinom gibt. Dies konnten sie in einer sogenannten Quantitativen Trait Locus (QTL)-Studie beweisen (Siltanen et al. 2013).

Eine erste Erkenntnis über die genaue Funktion von Arlts1 wurde kürzlich im Jahre 2018 publiziert. Die Studie zeigt erstmals die Expression dieses Gens in Makrophagen. Arlts1 reguliert hier die klassischen pro-inflammatorischen Wege in den Immunzellen als Antwort auf immunologische Stimuli, wie zum Beispiel einer Infektion mit Salmonella Typhimurium. Des Weiteren konnten die Autoren zeigen, dass Arlts1 eine regulatorische Funktion bezüglich des mitogen-activated-protein (MAP)-Kinase-Weges in Makrophagen einnimmt (Arya et al. 2018).

Es wurde gezeigt, dass eine Deletion auf Chromosom 13q14 in über 50\% der Fälle von Patienten mit einer Chronisch lymphatischen Leukämie (CLL) vorliegt (Sindelárová et al. 2005). Auf dieser Grundlage postulierten Calin et al., dass eine genetische Veränderung in ARLTS1, lokalisiert auf Chromosom 13q14, die Entstehung von CLL begünstige (Calin et al. 2005). In zwei darauffolgenden Studien konnte diese Hypothese für die maligne Erkrankung des Blutsystems nicht bestätigt werden (Sellick et al. 2006; Ng et al. 2007). Ebenfalls konnte keine Korrelation zwischen Polymorphismen in ARLTS1 und der Entwicklung eines Basalzellkarzinoms der Haut nachgewiesen werden (Li et al. 2007).

Arlts1 wurde bis heute nicht im Glioblastoma multiforme untersucht. 


\subsection{Zielsetzung}

Die erfolgreiche Behandlung des Glioblastoma multiforme als häufigster und aggressivster primärer Tumor des zentralen Nervensystems von Erwachsenen ist bis heute eine immense globale Herausforderung. Es gibt bislang keine Biomarker, die das Ziel einer erfolgreichen Therapie bieten oder für eine Früherkennung zur Verfügung stehen. Das GBM gilt zum derzeitigen Stand der Medizin als unheilbar.

Erste Untersuchungen in unserem Labor haben gezeigt, dass Cellular retinoic acid-binding protein 2 (CRABP2) die mRNA von ARLTS1 $24 \mathrm{~h}$ nach Transfektion stabilisiert. CRABP2 ist unter anderem für den Transport der Retinsäure in den Zellkern zuständig, sodass folglich die Transkription pro-apoptotischer Gene aktiviert werden kann (Dong et al. 1999). Daraus resultiert die Fragestellung, welche Rolle Arlts1 im GBM spielen könnte.

In dieser Arbeit wird das von verschiedenen familiär und sporadisch auftretenden Tumoren bekannte Tumorsuppressorgen ARLTS1 in der Glioblastomzelllinie U87 MG in vitro hinsichtlich seines Einflusses auf Apoptose und Migration untersucht. Diese Zelllinie wurde ausgewählt, da sie einen natürlichen Polymorphismus in c. T442C (p. Cys148Arg) in ARLTS1 aufweist. Wie bereits unter 1.2 erwähnt, steht diese genetische Variante im Zusammenhang mit der Entstehung diverser Tumoren. Dadurch soll die Rolle von Arlts1 erstmalig auch im GBM untersucht und beurteilt werden. 


\section{Materialien und Methoden}

\subsection{Materialien}

\subsubsection{Laborgeräte und Verbrauchsmaterialien}

Adhesive Sealing Sheets

BD FACS Aria II (FACS)

BD FACS Canto II (Durchflusszytometrie)

Brutschrank Typ B 5042 (ehemals Heraeus)

CFX384 Touch Real-Time PCR Detection System

CIM-Plate 16

CryoPure Gefäß, 1,8 ml

Elektrophoresekammer, Wide mini sub cell GT

Eppendorf BioPhotometer plus

Falcon tube 50ml-Reaktionsgefäß

Falcon $5 \mathrm{ml}$ Polystyrene Round Buttom Tube

Filterpapier, Chromatography Paper 3MM

Fresco 21 centrifuge

Glow Writer for Chemiluminescent Autography

Inkubator C200 Labotect, Zellkultur

Innova 4000, Inkubator und Schüttler, Bakterien

Konfokales Mikroskop, Leica LSM 710

Lichtmikroskop Primo Vert

Mini Trans-Blot ${ }^{\circledR}$ Cell

Molecular Imager® ChemiDoc XRS+

Neubauer Zählkammer (Tiefe 0,1 mm, 0,0025 mm²)

Nitrocellulose Blotting Membrane,

Amersham Protran 0, $2 \mu \mathrm{m} \mathrm{Nc}$

Pipettenspitzen

Platereader (Elx808 Absorbance Reader)

Power Pac 3000

Protein Concentrator PES, $10 \mathrm{~K}$ MWCO

Reagiergefäße Safe Seal

Schüttler, Ika-Vibrax-Vxr

Serological Pipette, 25, 10, $5 \mathrm{ml}$ (steril)

Steril GARD III Advance, Sterilbank
Thermo Scientific, Rockford

BD Bioscience, New Jersey

BD Bioscience, New Jersey

Thermo Scientific, Rockford

Bio-Rad Laboratories GmbH, München

ACEA Bioscience, San Diego

Sarstedt, Nümbrecht

Bio-Rad Laboratories GmbH, München

Eppendorf, Hamburg

Greiner Bio-one, Kremsmünster

Greiner Bio-one, Kremsmünster

Whatman, Maldstone

Thermo Scientific, Rockford

Diversified Biotech, Dedham

BeLoTec, Rosdorf

New Brunswick Scientific, Nürtingen

Zeiss, Jena

Zeiss, Jena

Bio-Rad Laboratories GmbH, München

Bio-Rad Laboratories GmbH, München

Karl Hecht GmbH, Sondheim

GE Healthcare Life Science, Freiburg

Sarstedt, Nümbrecht

Bio Tek, Winooski

Bio-Rad Laboratories GmbH, München

Thermo Scientific, Waltham

Sarstedt, Nümbrecht

Janke \& Kunkel GmbH, Staufen

Sarstedt, Nümbrecht

The Baker Company, Sanford 
Thermofrost Plus, Objektträger

Thermomixer compact

UVette 220-1600 nm, Kuvetten

Vortex-Genie 2

Wasserbad, C76 Water Bath Shaker

Well-Platte-96, Proteinbestimmung

Well-Platte-6, Zellkultur

Well-Platte-24, Zellkultur

Well-Platte-384, qPCR

xCELLigence ${ }^{\circledR}$ RTCA DP Instrument

Zellkratzer, $25 \mathrm{~cm}$

Zellkulturflasche, $75 \mathrm{~cm}^{2}$

Zellkulturzentrifuge, centrifuge 5702

\subsubsection{Chemikalien, Enzyme und Medien}

Acrylamid, $30 \%$, Bis solution

Agarose Basic BC

Albumin Standard (2mg/ ml)

Ammoniumperoxiddisulfat

Annexin-V (APC markiert)

Annexin-V Binding Buffer

Aqua PolyMount

BamHI\#RO136S, 20.000 U/ml

ß-Mercaptoethanol

Bromphenolblau

Bovines Serumalbumin Fraction V, BSA

Calciumchlorid

Chloroform

Chlorwasserstoff $37 \%$

Coomassie Brilliant Blue R-250

DAPI

DNA ladder, $1 \mathrm{~kb}$

dNTP Set, $4 \times 25 \mu \mathrm{mol}$

Dodecylsulfat Natriumsalz

Essigsäure 30\%
Gerhard Menzel GmbH, Braunschweig

Eppendorf, Hamburg

Eppendorf, Hamburg

Electro scientific industries

New Brunswick Scientific, Edison

4TiTude, Surrey

Greiner Bio-one, Kremsmünster

Greiner Bio-one, Kremsmünster

Thermo Scientific, Waltham

ACEA Bioscience, San Diego

Sarstedt, Nürnbrecht

Greiner Bio-one, Kremsmünster

Eppendorf, Hamburg

Bio-Rad Laboratories GmbH, München

AppliChem, Darmstadt

Thermo Scientific, Rockford

Sigma-Aldrich GmbH, Steinheim

Bio Legend, San Diego

Bio Legend, San Diego

Polysciences, Warrington

New England BioLabs, Ipswich

Sigma-Aldrich GmbH, Steinheim

Merck, Darmstadt

Roche Diagnostics, Rotkreuz

Merck, Darmstadt

Merck, Darmstadt

Merck, Darmstadt

Bio-Rad Laboratories GmbH, München

Sigma-Aldrich GmbH, Steinheim

New England BioLabs, Ipswich

Thermo Scientific, Rockford

Merck, Darmstadt

Merck, Darmstadt 
Ethanol absolut

Ethylendiamintetraessigsäure

Ethylenglykoltetraessigsäure

Folin \& Ciocalteau's phenol reagent

Formaldehydlösung, 4\%, Roti-Histofix

Gelantine gepulvert

Gel Loading Dye Blue, 6X

GelRed Nucleid Acid Gel Stain, 10.000X

Glycin

Glycerin, $87 \%$

Human Brain Total RNA

Igepal

Isopropanol

iTaq Universal SYBR Green Supermix

Kaliumdihydrogenphosphat

Kaliumchlorid

Kalium-Natrium-Tatrat

Kanamycin

KpnI \#RO142S, 10.000 U/ml

Kupfersulfat (Pentahydrat)

LB-Medium (Luria/ Miller)

MEM-minimum essential medium (1X)

Methanol

Milchpulver

Natriumcarbonat

Natriumchlorid

Natriumdesoxycholat

Natriumhydrogenphosphat

Natriumhydroxid

Natriumflouride

Natrium orthovanadat

NEAA (100X), Non-essential amino acid

Oligo-dT-Nukleotide, $50 \mu \mathrm{M}$

Page Ruler®Prestained protein ladder
Th. Gayer, Renningen

Merck, Darmstadt

Sigma-Aldrich GmbH, Steinheim

Sigma-Aldrich GmbH, Steinheim

Roth, Karlsruhe

Merck, Darmstadt

New England BioLabs, Ipswich

Biotrend Chemikalien GmbH, Köln

Merck, Darmstadt

AppliChem, Darmstadt

Clontech, Saint-Germain-en-Laye

Sigma-Aldrich GmbH, Steinheim

Roth, Karlsruhe

Bio-Rad Laboratories GmbH, München

Merck, Darmstadt

Merck, Darmstadt

Sigma-Aldrich GmbH, Steinheim

Roth, Karlsruhe

New England BioLabs, Ipswich

Merck, Darmstadt

Roth, Karlsruhe

Gibco, Life Technologies, Grand Island

Roth, Karlsruhe

Roth, Karlsruhe

Roth, Karlsruhe

AppliChem, Darmstadt

Merck, Darmstadt

Merck, Darmstadt

Merck, Darmstadt

Sigma-Aldrich GmbH, Steinheim

Sigma-Aldrich GmbH, Steinheim

Lonza, Verviers

Thermo Scientific, Rockford

Thermo Scientific, Waltham 
Poly-D-Lysin $(50 \mu \mathrm{g} / \mathrm{ml})$

Ponceau S solution, $0,1 \%$ in $5 \%$ acetic acid

Propidiumiodid $(1 \mathrm{mg} / \mathrm{ml})$

Protease inhibitor cocktail, cOmplete, EDTA-free

Random Hexamers, $50 \mu \mathrm{M}$

Rapid Ligation Buffer, 2X

Sodium Bicarbonate Solution 7, 5\%

Sodium Pyruvate 100mM (100X)

Standard Taq Polymerase Buffer, 10X

Taq DNA Polymerase, $5.000 \mathrm{U} / \mathrm{ml}$

TEMED-Tetramethylethylendiamine

Tris

Trinatriumtetraoxovanadat

T4 DNA Ligase, $400.000 \mathrm{U} / \mathrm{ml}$

Triton X-100

Trypsin-EDTA 0, 05\% (1X)

Tween ${ }^{\circledR 20}$

QIAzol Lysis Reagent

Zinkchlorid
Sigma-Aldrich GmbH, Steinheim

Sigma-Aldrich GmbH, Steinheim

Sigma-Aldrich GmbH, Steinheim

Roche Diagnostics GmbH, Mannheim

Thermo Scientific, Rockford

Promega, Fitchburg

Gibco, Life Technologies, Grand Island

Gibco, Life Technologies, Grand Island

New England BioLabs, Ipswich

New England BioLabs, Ipswich

Sigma-Aldrich GmbH, Steinheim

AppliChem, Darmstadt

Sigma-Aldrich GmbH, Steinheim

Promega, Fitchburg

Sigma-Aldrich GmbH, Steinheim

Gibco, Life Technologies, Grand Island

Merck, Darmstadt

Qiagen, Venlo

Sigma-Aldrich GmbH, Steinheim

\subsubsection{Puffer und Lösungen}

Alle Puffer und Lösungen sind, wenn nicht anders angegeben, mit bidestilliertem Wasser angesetzt worden.

Blocking Puffer

Destaining Solution

Incubation Buffer

Kalium-Natrium-Tatrat-Lösung, 2\%

Kupfersulfat-Lösung, $1 \%$

Laemmli-Elektrophoresepuffer (4X)
Milchpulver

Methanol

Essigsäure

Triton X-100

Tris-HCL, pH 7,5

$\mathrm{CaCl}_{2}$

$\mathrm{ZnCl}_{2}$

K-Na-Tatrat

$\mathrm{CuSO}_{4}$ (Pentahydrat)

Tris

pH 8,3 mit $\mathrm{HCl}$ eingestellt

SDS

Glycerin
$277 \mathrm{mM}$

$5 \%(\mathrm{w} / \mathrm{v})$

$20 \%(\mathrm{v} / \mathrm{v})$

$10 \%(\mathrm{v} / \mathrm{v})$

$1 \%(\mathrm{v} / \mathrm{v})$

$50 \mathrm{mM}$

$50 \mathrm{mM}$

$1 \mu \mathrm{M}$

$69 \mathrm{mM}$

$40 \mathrm{mM}$

$1 \mathrm{M}$

$40 \%(\mathrm{v} / \mathrm{v})$ 


\begin{tabular}{|c|c|c|}
\hline & ß-Mercaptoethanol & $20 \%(\mathrm{v} / \mathrm{v})$ \\
\hline & Bromphenolblau & $20 \%(\mathrm{v} / \mathrm{v})$ \\
\hline \multirow[t]{3}{*}{ Laufpuffer (5X) } & Tris & $124 \mathrm{mM}$ \\
\hline & Glycin & $1,25 \mathrm{M}$ \\
\hline & SDS & $0,5 \%(\mathrm{w} / \mathrm{v})$ \\
\hline \multirow[t]{3}{*}{ Lower Buffer pH 8, 8} & Tris & $1,5 \mathrm{M}$ \\
\hline & SDS & $0,4 \%(\mathrm{w} / \mathrm{v})$ \\
\hline & $\mathrm{pH} 8,8$ mit $\mathrm{HCl}$ eingestellt & \\
\hline \multirow[t]{10}{*}{ Lysis Buffer pH 8, 3} & Tris & $50 \mathrm{mM}$ \\
\hline & $\mathrm{pH} 8,3$ mit $\mathrm{HCl}$ eingestellt & \\
\hline & $\mathrm{NaCl}$ & $150 \mathrm{mM}$ \\
\hline & $\mathrm{NaF}$ & $40 \mathrm{mM}$ \\
\hline & EDTA & $5 \mathrm{mM}$ \\
\hline & EGTA & $5 \mathrm{mM}$ \\
\hline & $\mathrm{Na}_{3} \mathrm{VO}_{4}$ & $1 \mathrm{mM}$ \\
\hline & Igepal & $1 \%(\mathrm{v} / \mathrm{v})$ \\
\hline & Natriumdesoxycholat & $0,1 \%(\mathrm{w} / \mathrm{v})$ \\
\hline & SDS & $0,1 \%(\mathrm{w} / \mathrm{v})$ \\
\hline \multirow[t]{2}{*}{ Natriumcarbonat-Lösung, $2 \%$} & $\mathrm{Na}_{2} \mathrm{CO}_{3}$ & $189 \mathrm{mM}$ \\
\hline & in $0,1 \mathrm{M} \mathrm{NaOH}$ & \\
\hline Natriumhydroxid-Lösung & $\mathrm{NaOH}$ & $0,1 \mathrm{M}$ \\
\hline \multirow[t]{4}{*}{ Non-reducing Buffer (5X) } & SDS & $4 \%(\mathrm{w} / \mathrm{v})$ \\
\hline & $20 \%$ Glycerol & $20 \%(\mathrm{v} / \mathrm{v})$ \\
\hline & Bromphenolblau & $0,01 \%(\mathrm{w} / \mathrm{v})$ \\
\hline & Tris-HCL, pH 6,8 & $125 \mathrm{mM}$ \\
\hline \multirow[t]{4}{*}{$\operatorname{PBS}(1 \mathrm{X}) \mathrm{pH} 7,4$} & $\mathrm{NaCl}$ & $137 \mathrm{mM}$ \\
\hline & $\mathrm{KCl}$ & $2,7 \mathrm{mM}$ \\
\hline & $\mathrm{Na}_{2} \mathrm{HPO}_{4}$ & $10 \mathrm{mM}$ \\
\hline & $\mathrm{KH}_{2} \mathrm{PO}_{4}$ & $1,8 \mathrm{mM}$ \\
\hline
\end{tabular}

Protease inhibitor cocktail,

complete, EDTA-free (25X)

1 Tablette wurde in $2 \mathrm{ml} 1 \mathrm{X}$ PBS aufgelöst

Staining Solution

Methanol

$20 \%(\mathrm{v} / \mathrm{v})$

Essigsäure $30 \%$

$5 \%(\mathrm{v} / \mathrm{v})$

Coomassie Blue

$0,05 \%(\mathrm{w} / \mathrm{v})$ 
Stripping Buffer

TAE (50X)

TBS pH 7, 4 (20X)

TBST pH 7, 4 (1X)

Transferpuffer (5X)

Transferpuffer (1X)

Upper Buffer pH 6, 8

Washing Buffer (Zymographie)
Tris

$62,5 \mathrm{mM}$

pH 6,8 mit $\mathrm{HCl}$ eingestellt

SDS

ß-Mercaptoethanol

Tris

Essigsäure

EDTA $(\mathrm{pH} \mathrm{8,0)}$

Tris

$\mathrm{NaCl}$

20X TBS

Tween ${ }^{\circledR} 20$

Tris

Glycin

5X Transferpuffer

Methanol

Tris

SDS

pH 6,8 mit $\mathrm{HCl}$ eingestellt

$2,5 \%$ Triton $\mathrm{X}-100$

Tris-HCL, pH 7,5

$\mathrm{CaCl}_{2}$

$\mathrm{ZnCl}_{2}$
$2,5 \%(\mathrm{v} / \mathrm{v})$

$2 \%(\mathrm{w} / \mathrm{v})$

$100 \mathrm{mM}$

$30 \mathrm{mM}$

$3,4 \mathrm{mM}$

$0,5 \mathrm{M}$

$50 \mathrm{mM}$

$150 \mathrm{mM}$

$0,05 \%(\mathrm{v} / \mathrm{v})$

$100 \mathrm{mM}$

$0,8 \mathrm{M}$

$20 \%(\mathrm{v} / \mathrm{v})$

$20 \%(\mathrm{v} / \mathrm{v})$

$0,5 \mathrm{M}$

$0,4 \%(\mathrm{~m} / \mathrm{v})$

$50 \mathrm{mM}$

$5 \mathrm{mM}$

$1 \mu \mathrm{M}$

\subsubsection{Reaktionskits}

Lipofectamine $^{\mathrm{TM}} 3000$ Transfection kit

Life Technologies, Carlsbad

NucleoSpin Gel and PCR Clean-up

Macherey-Nagel, Düren

NucleoSpin Plasmid Quick Pure

Macherey-Nagel, Düren

Western Lightening® Ultra

PerkinElmer, Waltham

miRNeasy ${ }^{\circledR}$ Mini Kit (50)

Qiagen, Hilden

QIAfilter Plasmid Midi Kit

Qiagen, Hilden

Superscript III® (Superscript, $1^{\text {st }}$ strand buffer, 0, 1 M DTT)

Life Technologies, Carlsbad 


\subsubsection{Primäre Antikörper}

\begin{tabular}{|c|c|c|c|c|}
\hline Bezeichnung & Spezies & Anwendung & Hersteller & Verdünnung \\
\hline $\mathrm{Bcl}-2 \mathrm{mAb}$ & rabbit & Western Blot & Cell signaling & $1: 1000$ \\
\hline B-Actin $\mathrm{mAB}$ & mouse & Western Blot & Abcam & $1: 5000$ \\
\hline
\end{tabular}

\subsubsection{Sekundäre Antikörper}

\begin{tabular}{|c|c|c|c|c|}
\hline Bezeichnung & Spezies & Anwendung & Hersteller & Verdünnung \\
\hline $\begin{array}{c}\text { Anti-rabbit IgG, } \\
\text { HRP-linked An- } \\
\text { tibody }\end{array}$ & $\begin{array}{c}\text { Goat anti- } \\
\text { rabbit }\end{array}$ & Western Blot & Cell signaling & $1: 2000$ \\
\hline $\begin{array}{c}\text { Anti-mouse } \\
\text { HRP-linked An- } \\
\text { tibody }\end{array}$ & $\begin{array}{c}\text { Goat anti- } \\
\text { mouse }\end{array}$ & Western Blot & Santa Cruz & $1: 2000$ \\
\hline
\end{tabular}

\subsubsection{Oligonukleotide}

\begin{tabular}{|c|c|}
\hline $\begin{array}{c}\text { Oligonukleotid für Quantitative } \\
\text { Real Time PCR }\end{array}$ & Sequenz \\
\hline human HMBS fw & CGCATCTGGAGTTCAGGAGTA \\
\hline human HMBS rev & CCAGGATGATGGCACTGA \\
\hline human Arlts $1 \mathrm{fw}$ & GCAAGACCACGCTCCTTTACA \\
\hline human Arlts1 rev & CTGTGCCTTCCAGATAGTCCTT \\
\hline human BCL2 fw & CTGCACCTGACGCCCTTCACC \\
\hline human BCL2 rev & CACATGACCCCACCGAACTCAAAGA \\
\hline human Caspase $3 \mathrm{fw}$ & TTCAGAGGGGATCGTTGTAGAAGTC \\
\hline human Caspase $3 \mathrm{rev}$ & CAAGCTTGTCGGCATACTGTTTCAG \\
\hline human Caspase $7 \mathrm{fw}$ & GCTGACTTCCTCTTCGCCTA \\
\hline human Caspase $7 \mathrm{rev}$ & CAAACCAGGAGCCTCTTCCT \\
\hline human Caspase $9 \mathrm{fw}$ & AAGCCCAAGCTCTTTTTCATC \\
\hline human Caspase $9 \mathrm{rev}$ & ACTCGTCTTCAGGGGAAGTG \\
\hline human MMP2 fw & TCTCCTGACATTGACCTTGGC \\
\hline human MMP2 rev & CAAGGTGCTGGCTGAGTAGATC \\
\hline human MMP9 fw & TTGACAGCGACAAGAAGTGG \\
\hline human MMP9 rev & GCCATTCACGTCGTCCTTAT \\
\hline
\end{tabular}

\begin{tabular}{|c|c|}
\hline Oligonukleotid für PCR & Sequenz \\
\hline & GGGGTACCTATGGGTTCTGTGAATT- \\
Arlts1-kpn1 fw & CCAG \\
\hline Arlts1-BamHI without stop codon \\
rev & CGGGATCCGCAGATCTCTT- \\
\end{tabular}

\subsubsection{Software}

Graph Pad Prism 5 (statistische Auswertung), ZEN 2011 (Konfokale Mikroskopie), BD FACSDiva (Durchflusszytometrie), RTCA Data Analysis Software (Migrationsassay). 


\subsection{Methoden}

\subsubsection{Klonierung von pEGFP-N1-Arlts1}

\subsubsection{Herstellen von cDNA}

Zunächst wurde „Human Brain total RNA“ (Clontech) in eine komplementäre DNA (cDNA) umgeschrieben, um anschließend eine konventionelle Polymerase-Kettenreaktion (PCR) durchführen zu können. Die Oligo-dT-Nukleotide binden an dem Poly-ASchwanz der Ribonukleinsäure (RNA) und dem Random-Hexamer zufällig an den ihnen komplementären Abschnitten. Beide dienen als Primer und somit als Ausgangspunkt für die Reverse Transkriptase (Superscript III). Folgender Ansatz wurde in einem 0,5 ml Reaktionsgefäß angesetzt, gemischt und kurz zentrifugiert:

Tabelle 1: Pipettierschema für die Herstellung von cDNA-Ansatz I

\begin{tabular}{|l|l|}
\hline Komponente & Konzentration \\
\hline „Human Brain total RNA“ & $5 \mu \mathrm{g}$ \\
\hline $1 \mu \mathrm{l}$ Oligo-dT-Nukleotide & $0,6 \mathrm{pmol} / \mu \mathrm{l}$ \\
\hline $1 \mu \mathrm{l}$ Random-Hexamers & $120 \mathrm{pmol} / \mu \mathrm{l}$ \\
\hline
\end{tabular}

Dieser Ansatz I wurde für zwei Minuten (min) bei $70{ }^{\circ} \mathrm{C}$ in einem Thermocycler (Biometra) inkubiert. Währenddessen konnte ein Master Mix aus folgenden Komponenten hergestellt werden:

Tabelle 2: Pipettierschema für die Herstellung von cDNA-Ansatz II

\begin{tabular}{|l|l|}
\hline Komponente & Konzentration /Menge \\
\hline $4 \mu 11^{\text {st }}$ Strand buffer & $5 \mathrm{X}$ \\
\hline $2 \mu \mathrm{l}$ Dithiotreitol (DTT) & $0,1 \mathrm{M}$ \\
\hline $1 \mu \mathrm{dNTPs}$ & $10 \mathrm{mM}$ jedes Nukleotid \\
\hline $1 \mu \mathrm{l}$ Superscript III & $200 \mathrm{U} / \mu \mathrm{l}$ \\
\hline
\end{tabular}

Der Master Mix wurde gut gemischt und zum Reaktionsansatz I hinzugegeben. Nach einer kurzen Zentrifugation ist der vollständige Ansatz in den Thermocycler gestellt worden. Die Inkubationsschritte von $10 \mathrm{~min}$ bei $25{ }^{\circ} \mathrm{C}, 45 \mathrm{~min}$ bei $50{ }^{\circ} \mathrm{C}$ und abschließend 45 min bei $55^{\circ} \mathrm{C}$ wurden eingehalten. Die cDNA konnte bei $-20{ }^{\circ} \mathrm{C}$ aufbewahrt werden.

\subsubsection{PCR für die Amplifikation von dem Insert ARLTS1}

Wie bereits oben beschrieben (siehe 2.2.1.1) dient die cDNA als Vorlage für das Insert (ARLTS1). Das Insert wurde mittels PCR mit spezifischen Primern amplifiziert (siehe Tabelle 3). Die Primer wurden so angefertigt, dass sie an den Enden die entsprechenden Erkennungssequenzen für Restriktionsendonukleasen enthielten. 
Tabelle 3: Protokoll für die Insert-PCR

\begin{tabular}{|l|l|l|}
\hline Komponente & Konzentration & Volumen \\
\hline cDNA total human brain & $100 \mu \mathrm{g} / \mu \mathrm{l}$ & $1 \mu \mathrm{l}$ \\
\hline Taq Polymerase Buffer & $10 \mathrm{X}$ & $5 \mu \mathrm{l}$ \\
\hline Primer forward Arlts 1 & $10 \mathrm{pmol} / \mu \mathrm{l}$ & $1 \mu \mathrm{l}$ \\
\hline Primer reverse Arlts 1 & $10 \mathrm{pmol} / \mu \mathrm{l}$ & $1 \mu \mathrm{l}$ \\
\hline dNTPs & $10 \mathrm{mM}$ jedes Nukleotid & $5 \mu 1$ \\
\hline Steriles Wasser & - & $40,5 \mu \mathrm{l}$ \\
\hline Taq DNA Polymerase & $5.000 \mathrm{U} / \mathrm{ml}$ & $0,5 \mu \mathrm{l}$ \\
\hline
\end{tabular}

Der Cycler wurde folgendermaßen programmiert: $95{ }^{\circ} \mathrm{C}$ Denaturierung der doppelsträngigen DNA für 30 Sekunden (s), Annealing der Primer bei $69^{\circ} \mathrm{C}$ für ebenfalls $30 \mathrm{~s}$ und Elongation bei $68{ }^{\circ} \mathrm{C}$ für $45 \mathrm{~s}$. Insgesamt wurden 45 Zyklen durchlaufen.

\subsubsection{Agarosegelelektrophorese und Extraktion aus dem Gel}

Der Reaktionsansatz wurde nach Ablauf der PCR auf ein 1\%-iges Agarose-Gel aufgetragen und die amplifizierte DNA elektrophoretisch aufgetrennt. Die entsprechende Menge Agarose wurde abgewogen und mit TAE-Puffer in der Mikrowelle aufgelöst. Nach kurzer Abkühlungszeit wurden $10 \mu \mathrm{l}$ GelRed zu den $150 \mathrm{ml}$ TAE/ Agarose hinzugegeben. Das GelRed interkaliert mit Nukleinsäuren und fluoresziert unter UV-Licht. Der komplette PCR-Ansatz wurde mit $8 \mu$ l Loading Dye (6X) vermischt. Das Mitführen eines Markers ist wichtig, damit man eine Referenz für die Größe der aufgetrennten DNA bestimmen kann. Die Elektrophorese wurde in einer Kammer, befüllt mit TAE-Puffer, bei 120 Volt (V) für 40 min durchgeführt. Unter UV-Licht wurde die Bande entsprechend der Größe für das Insert sichtbar. Diese wurde aus dem Gel ausgeschnitten und mithilfe des Kits „NucleoSpin Gel and PCR Clean-up“ (Macherey-Nagel) nach Herstellerangaben aufgereinigt. Die DNA wurde in $30 \mu 1$ steriles Wasser eluiert.

\subsubsection{Restriktionsenzymverdau}

Der Vektor, in dieser Arbeit das Plasmid pEGFP-N1 (von der Arbeitsgruppe Neuroimmunologie unter Leitung von Herrn Professor Flügel, Institut für Multiple-Sklerose-Forschung in Göttingen zur Verfügung gestellt), und das Insert wurden mit den Restriktionsenzymen KpnI und BamHI geschnitten. Zunächst wurde der Verdau mit KpnI durchgeführt: 
Tabelle 4: Pipettierschema für den Enzymverdau mit KpnI

\begin{tabular}{|l|l|l|l|}
\hline Komponente & $\begin{array}{l}\text { Konzentration/ } \\
\text { Menge }\end{array}$ & Volumen „Insert “ & \multicolumn{1}{c|}{$\begin{array}{c}\text { Volumen } \\
\text {,Vektor“6 }\end{array}$} \\
\hline DNA & $1 \mu \mathrm{g}$ & $30 \mu \mathrm{l}$ & $1,05 \mu \mathrm{l}$ \\
\hline NEBuffer 1.1 & $10 \mathrm{X}$ & $5 \mu \mathrm{l}$ & $5 \mu 1$ \\
\hline KpnI Enzym & $10.000 \mathrm{U} / \mathrm{ml}$ & $1 \mu \mathrm{l}$ & $1 \mu 1$ \\
\hline Steriles Wasser & - & $14 \mu \mathrm{l}$ & $42,9 \mu \mathrm{l}$ \\
\hline
\end{tabular}

Die beiden Ansätze wurden für zwei Stunden (h) bei $37{ }^{\circ} \mathrm{C}$ in einem Thermomixer inkubiert. Durch das Auftragen auf ein 1\%-Agarosegel und Elektrophorese konnte die erfolgreiche Linearisierung überprüft werden. Anschließend wurde eine Aufreinigung der DNA aus dem Reaktionsansatz mithilfe des Kits „NucleoSpin Gel and PCR Clean-up“ (Macherey-Nagel) nach Herstellerangaben durchgeführt. Es folgte der Verdau mit BamHI über Nacht bei $37^{\circ} \mathrm{C}$.

Tabelle 5: Pipettierschema für den Enzymverdau mit BamHI

\begin{tabular}{|l|l|l|l|}
\hline Komponente & Konzentration/ Menge & \multicolumn{1}{|c|}{$\begin{array}{c}\text { Volumen } \\
\text { „Insert “* }\end{array}$} & $\begin{array}{c}\text { Volumen } \\
\text {,Vektor“6 }\end{array}$ \\
\hline DNA & $1 \mu \mathrm{g}$ & $28 \mu \mathrm{l}$ & $28 \mu \mathrm{l}$ \\
\hline NEBuffer 3.1 & $10 \mathrm{X}$ & $5 \mu \mathrm{l}$ & $5 \mu \mathrm{l}$ \\
\hline BamHI Enzym & $20.000 \mathrm{U} / \mathrm{ml}$ & $1 \mu \mathrm{l}$ & $1 \mu \mathrm{l}$ \\
\hline Steriles Wasser & - & $16 \mu \mathrm{l}$ & $16 \mu \mathrm{l}$ \\
\hline
\end{tabular}

Dieser Reaktionsansatz wurde am folgenden Tag ebenfalls aufgereinigt.

\subsubsection{Ligation von DNA-Fragmenten}

Bei der Ligation wurden die zwei DNA-Fragmente, Insert und Vektor, unter Verwendung des Enzyms Ligase verknüpft. Unter Ausbildung einer Phosphodiesterbindung wurden 3'-Hydroxy-Ende und 5'-Phosphat-Ende zusammengefügt.

Der Reaktionsansatz wurde nach dem folgenden Schema pipettiert und durch vorsichtiges Auf- und Abpipettieren gemischt.

Tabelle 6: Pipettierschema für die Ligation von pEGFP-N1 und ARLTS1

\begin{tabular}{|l|l|l|l|}
\hline Komponente & Konzentration & $\begin{array}{c}\text { Volumen } \\
\text {,3:1-An- } \\
\text { satz }^{66}\end{array}$ & $\begin{array}{c}\text { Volumen ,Kontrolle } \\
\text { ohne Insert }\end{array}$ \\
\hline Vektor pEGFP-N1 & - & $3 \mu 1$ & $3 \mu 1$ \\
\hline Insert ARLTS1 & - & $1 \mu 1$ & - \\
\hline T4 DNA Ligase & $400.000 \mathrm{U} / \mathrm{ml}$ & $1 \mu 1$ & $1 \mu 1$ \\
\hline Rapid Ligation Buffer & $2 \mathrm{X}$ & $5 \mu 1$ & $5 \mu 1$ \\
\hline Steriles Wasser & - & - & $1 \mu 1$ \\
\hline
\end{tabular}

Der Ansatz für die Ligation wurde über Nacht bei $4{ }^{\circ} \mathrm{C}$ inkubiert. 


\subsubsection{Bakterienkultur}

Als kompetente Zellen wurden in dieser Arbeit die Xl-1 blue Escherichia coli (E. coli) verwendet. Als kompetent werden diejenigen Zellen bezeichnet, deren Membran durchlässig für DNA ist. Die Kompetenz ist somit Voraussetzung für die Transformation. Die kompetenten E. coli wurden nach dem Protokoll von Green und Rogers hergestellt (Green und Rogers 2013).

\subsubsection{Transformation von kompetenten E. coli}

Zu $100 \mu 1$ Xl-1 blue E. coli wurden $5 \mu \mathrm{l}$ des Ligationsansatzes bzw. des Kontrollansatzes hinzugefügt, vorsichtig vermischt und für 30 min auf Eis inkubiert. Ein Hitzeschock in einem $42{ }^{\circ} \mathrm{C}$ warmen Wasserbad für $45 \mathrm{~s}$ ermöglichte die Transformation des Plasmids in die kompetenten Zellen. Die Reaktionsgefäße wurden nach dem Hitzeschock sofort wieder auf Eis gesetzt und dort für 2 min inkubiert. Anschließend wurden $900 \mu 1$ vorgewärmtes LB (lysogeny-broth)-Medium ohne Antibiotikum hinzugefügt. In einem Thermomixer bei $37^{\circ} \mathrm{C}$ wurden die Zellen bereits für 45 min angezüchtet.

Die kompetenten E. coli wurden auf Agarplatten mit Kanamycin $(50 \mu \mathrm{g} / \mathrm{ml})$ ausplattiert und über Nacht in einem $37{ }^{\circ} \mathrm{C}$ warmen Brutschrank inkubiert. Am folgenden Tag wurde die Anzahl der Kolonien zwischen Kontroll- und Ligationsansatz verglichen.

\subsubsection{Kolonie-PCR}

Zur Kontrolle des Erfolgs der Transformation wurde eine sogenannte Kolonie-PCR durchgeführt. Dazu wurde als Template mit einer Pipettenspitze Material von einer auf der Platte gewachsenen Kolonie entnommen und in $20 \mu 1$ sterilem Wasser geschwenkt. Tabelle 7 zeigt das Pipettierschema für die PCR. In der Negativkontrolle wurde kein Template in das sterile Wasser gegeben.

Die Pipettenspitze wurde anschließend in einem Erlenmeyerkolben mit $5 \mathrm{ml}$ LB-Medium mit Kanamycin $(50 \mu \mathrm{g} / \mathrm{ml})$ überführt und im Kühlschrank aufbewahrt. Im Falle einer positiven Kolonie- $P C R$ wurde für die Isolierung von Plasmid-DNA der Erlenmeyerkolben bei $37^{\circ} \mathrm{C}$ in einen Schüttler gestellt, sodass die Bakterien über Nacht wachsen konnten. 
Tabelle 7: Pipettierschema für eine Probe einer Kolonie-PCR

\begin{tabular}{|l|l|l|}
\hline Komponente & Konzentration & Volumen \\
\hline Template (Kolonie in Wasser) & \multicolumn{1}{|c|}{-} & $20 \mu \mathrm{l}$ \\
\hline Taq Polymerase Buffer & $10 \mathrm{X}$ & $5 \mu \mathrm{l}$ \\
\hline Primer forward Arlts 1 & $10 \mathrm{pmol} / \mu \mathrm{l}$ & $1 \mu \mathrm{l}$ \\
\hline Primer reverse Arlts 1 & $10 \mathrm{pmol} / \mu \mathrm{l}$ & $1 \mu \mathrm{l}$ \\
\hline Taq DNA Polymerase & $5.000 \mathrm{U} / \mathrm{ml}$ & $0,5 \mu \mathrm{l}$ \\
\hline Steriles Wasser & \multicolumn{1}{c|}{-} & $21,5 \mu \mathrm{l}$ \\
\hline dNTPs & $10 \mathrm{mM}$ jedes Nukleotid & $1 \mu \mathrm{l}$ \\
\hline
\end{tabular}

Der Thermocycler wurde mit einer Denaturierung von $95{ }^{\circ} \mathrm{C}$ für $30 \mathrm{~s}$, Annealing von $69{ }^{\circ} \mathrm{C}$ für $30 \mathrm{~s}$ und Elongation von $68^{\circ} \mathrm{C}$ für $45 \mathrm{~s}$ für 45 Zyklen programmiert. Das PCR Produkt wurde auf ein 1\%-iges Agarosegel mit GelRed aufgetragen, elektrophoretisch bei $120 \mathrm{~V}$ aufgetrennt und unter UV-Licht detektiert.

\subsubsection{Isolierung von Plasmid-DNA}

Mithilfe des Kits „NucleoSpin Plasmid Quick Pure“ (Machery-Nagel) wurde die DNA nach Angaben des Herstellers aus den $\mathrm{Xl-1}$ Blue E. coli isoliert und in $50 \mu 1$ sterilem Wasser eluiert. Anschließend wurde die Konzentration der DNA photometrisch gemessen (Eppendorf photometer plus).

\subsubsection{Sequenzierung}

Die isolierte DNA wurde auf eine Konzentration von $100 \mathrm{ng} / \mu 1$ mit sterilem Wasser verdünnt und zur Sequenzierung (Max-Planck-Institut für Experimentelle Medizin) nach der Methode von Sanger (Sanger und Coulson 1975) gegeben. Es wurden vektorspezifische Primer verwendet, die vom Sequenzierlabor gestellt wurden.

\subsubsection{Zellkultur}

\subsubsection{Zelllinie und deren Kultivierung}

Für diese Arbeit wurde die Glioblastom-Zelllinie U87 MG verwendet. Die Zelllinie wurde von Julia Bode (Molecular Mechanisms of Tumor Invasion, Schaller Research Group, Universität Heidelberg und DKFZ) zur Verfügung gestellt.

Ein Reaktionsgefäß mit aliquotierten Zellen wurde aus einem $-80{ }^{\circ} \mathrm{C}$ Gefrierschrank auf Eis entnommen und anschließend bei $37{ }^{\circ} \mathrm{C}$ erwärmt. Die Zellen wurden in ein für die Zentrifuge geeignetes Gefäß überführt und gleichzeitig $10 \mathrm{ml}$ MEM (minimum essential medium) + FCS (fetal calf serum) hinzugefügt. Die Zellsuspension wurde $20 \mathrm{Mal}$ auf und ab pipettiert, um eine ausreichende Verteilung der Tumorzellen zu erreichen. Die 
Suspension wurde bei $700 \mathrm{rpm}$ für 5 min zentrifugiert und das Pellet mit $1 \mathrm{ml}$ Medium resuspendiert. Das gesamte Volumen wurde in eine Zellkulturflasche (Greiner bio-one, $75 \mathrm{~cm}^{2}$ ) mit $20 \mathrm{ml}$ MEM+FCS Medium pipettiert (zu MEM $500 \mathrm{ml}$ von Gibco wurden 10\% FCS, 1 mM Sodium Pyruvate, 0,1 mM 100X NEAA, 0,75 g Sodium Bicarbonate hinzugefügt). In einem Zellinkubator wurde die Flasche bei $37{ }^{\circ} \mathrm{C}$ und einer Atmosphäre von $5 \% \mathrm{CO}_{2}$ inkubiert und somit eine optimale Bedingung zur Zellteilung hergestellt.

\subsubsection{Aussäen der Zellen}

Die U87-MG-Zellen sind in der Zellkulturflasche etwa drei bis fünf Tage gewachsen, bis eine optische Konfluenz von ungefähr $80 \%$ erreicht worden ist. Das Medium wurde vollständig entfernt und dafür $5 \mathrm{ml}$ vorgewärmtes Trypsin ( $0,05 \%$ von Gibco) hinzugefügt. Die Zellkulturflasche mit dem Trypsin ist für $3 \mathrm{~min}$ in den Inkubator bei $37^{\circ} \mathrm{C}$ gestellt worden. $10 \mathrm{ml}$ vorgewärmtes MEM+FCS haben das Trypsin neutralisiert. Das komplette Medium mit den Zellen wurde in einem Reaktionsgefäß gesammelt. Die Zellsuspension in dem Reaktionsgefäß wurde für 3 min bei 1200 rpm zentrifugiert. Der Überstand wurde vollständig abgenommen und das Pellet in 1ml MEM+FCS vorsichtig resuspendiert.

Die Zellen wurden in einer 6-Well-Platte beziehungsweise in einer 24-Well-Platte (Greiner bio-one), je nach anschließender Versuchsdurchführung, ausgesät und auf das zuvor berechnete Gesamtvolumen aufgefüllt.

Für die Gewinnung von Protein, RNA oder Zellen für Durchflusszytometrie, FACS (Fluorescence activated cell sorting) und Zymographie wurden 300000 Zellen pro Well in einem Gesamtvolumen von 2 ml MEM+FCS ausgesät.

Für die Konfokale Mikroskopie wurden 50000 Zellen pro Well in einer 24-Well-Platte ausgesät. Zunächst wurde in jedes Well ein Glasplättchen gelegt, $400 \mu 1$ PDL (Poly-DLysin) mit einer Konzentration von $50 \mu \mathrm{g} / \mathrm{ml}$ hinzugefügt und für $30 \mathrm{~min}$ in den Zellinkubator gestellt. Das PDL ermöglichte die Adhärenz der Zellen auf dem Glasplättchen. Anschließend wurde das PDL entfernt, einmalig mit sterilem Wasser gewaschen und getrocknet. Nach der oben beschriebenen Methode wurden nun für die 24-Well-Platte 50000 Zellen pro Well in MEM+FCS ausgesät.

\subsubsection{Transfektion}

Die Plasmid-DNA wurde mittels Transfektion in die Glioblastomzellen eingebracht. Als Transfektionsmittel wurde Lipofectamin® verwendet. $24 \mathrm{~h}$ nach dem Aussäen wurde das Plasmid pEGFP-N1/pEGFP-N1-Arlts1 in die U87-MG-Zellen transfiziert. Für das 
Plasmid pcDNA4/pcDNA4-CRABP2 wurde zunächst nach $24 \mathrm{~h}$ das Medium ohne FCS gewechselt und die Transfektion erst am folgenden Tag durchgeführt.

Die Transfektion der Zellen in der 6-Well-Platte wurde nach Angaben des Herstellers (Invitrogen) durchgeführt. In einem Master Mix wurden 3,5 $\mu \mathrm{g}$ von pEGFP-N1/pEGFPN1-Arlts1 beziehungsweise $4 \mu \mathrm{g}$ von pcDNA4/pcDNA4-CRABP2 mit 247,5 $\mu 1$ MEM und $10 \mu 1$ P3000тм Reagent vermischt. Bei den Ansätzen für die Transfektionen ist es wichtig, dass man MEM ohne FCS verwendet. Das FCS würde die Bildung von Liposomen aus Lipofectamin $®$ und DNA verhindern. Für eine Negativkontrolle wurde ein Ansatz mit $250 \mu 1$ MEM ohne DNA hergestellt.

In einem zweiten Ansatz wurden 7,5 $\mu$ l Lipofectamin ${ }^{3}$ 3000Reagent mit 242,5 $\mu 1$ MEM verdünnt. Beide Ansätze wurden separat für 5 min inkubiert und anschließend zusammengeführt. Danach wurde für weitere 10 min inkubiert. In dieser Zeit wurde das Medium von den U87-MG-Zellen vollständig entfernt. Zu jedem Well wurden $500 \mu 1$ der Transfektionsmischung pipettiert. Die 6-Well-Platte wurde in den Inkubator gestellt. Nach $6 \mathrm{~h}$ wurden zu der Transfektion mit pEGFP-N1 $500 \mu \mathrm{l}$ MEM+FCS zu jedem Well hinzugefügt, bei der Transfektion mit pcDNA wurde darauf verzichtet. Für die Zymographie und das FACS wurde Medium ohne FCS nach $6 \mathrm{~h}$ hinzugefügt, weil FCS die Qualität der Assays beeinflusst hätte.

Für die Transfektion der Zellen in der 24-Well-Platte wurden 700 ng der jeweiligen Plasmid-DNA verwendet. Sie wurde nach Angaben des Herstellers (Invitrogen) durchgeführt.

\subsubsection{Protein}

\subsubsection{Proteinextraktion für die Western Blots}

Die Proteine der U87 MG Glioblastomzellen wurden 24 h nach der Transfektion geerntet. Die Zellen wurden auf Eis platziert und das Medium vollständig entfernt. Nach einem Waschschritt mit gekühltem PBS wurde zu jeder Bedingung $100 \mu 1$ Lysis Buffer auf die Zellen pipettiert. Mithilfe eines Zellkratzers wurden die Zellen vom Boden abgelöst und in einem Reaktionsgefäß gesammelt. Das Proteingemisch wurde mit einer gelben Pipettenspitze zehn Mal auf und ab pipettiert, um das Protein zu resuspendieren. Anschließend wurde das Reaktionsgefäß für 10 min auf Eis inkubiert. Die Proteine wurden für $20 \mathrm{~min}$ bei $14000 \mathrm{rpm}$ bei $4{ }^{\circ} \mathrm{C}$ zentrifugiert. Ein Teil $(15 \mu \mathrm{l})$ des Überstandes wurde für eine Proteinbestimmung abgenommen. Zu jeder Proteinprobe wurde ein Drittel Laemmli- 
Elektrophoresepuffer (4X) hinzugefügt. Die Proteine wurden bei $95{ }^{\circ} \mathrm{C}$ für 5 min denaturiert. Die Proben konnten bei $-80{ }^{\circ} \mathrm{C}$ aufbewahrt werden.

\subsubsection{Proteinextraktion für die Zymographie}

Für die Zymographie wurden sowohl die Zellen als auch das Medium nach 48 h geerntet. Das Medium wurde abgenommen und zunächst in einem Falcon Tube zentrifugiert, um Zelltrümmer zu beseitigen. Der Überstand wurde anschließend in mehreren Schritten in sogenannten Protein Concentrator Tubes zentrifugiert und konzentriert. Diese Gefäße besitzen einen Filter, welcher nur Proteine mit einem Molekulargewicht kleiner als $10 \mathrm{kDa}$ durchlässt.

Die U87-MG-Zellen wurden nach demselben Protokoll wie für die Western Blots geerntet (2.2.3.1). Für die Zymographie wurden allerdings die Proteine weder mit Laemmli versetzt, noch durch Hitze denaturiert. Durch eine Denaturierung würde zwar die Primärstruktur eines Proteins erhalten bleiben, aber gleichzeitig die in der Zymographie zu testende biologische Funktionalität beeinträchtigt werden. Für die anschließende Proteinbestimmung wurden $10 \mu 1$ abgenommen.

\subsubsection{Proteinbestimmung}

Die quantitative Proteinbestimmung erfolgte nach dem Prinzip von Lowry (Lowry et al. 1951). Es beruht auf einer Reaktion der Peptidbindungen mit zweiwertigem Kupfer in alkalischer Lösung. Die Absorption lässt sich photometrisch messen. Dabei ist die Farbintensität proportional zum Proteingehalt.

Zunächst wurde eine Verdünnungsreihe aus einem Albuminstandard angesetzt. Die Stammlösung hatte eine Konzentration von $1 \mathrm{mg} / \mathrm{ml}$. In 2-ml-Reaktionsgefäßen wurden folgende Endkonzentrationen hergestellt: $1 \mu \mathrm{g}, 2,5 \mu \mathrm{g}, 5 \mu \mathrm{g}, 7,5 \mu \mathrm{g}, 10 \mu \mathrm{g}, 12,5 \mu \mathrm{g}$, $15 \mu \mathrm{g}, 20 \mu \mathrm{g}$. Diese Verdünnungsreihe diente als Standardkurve für die Proteinproben. Je $2 \mu 1$ jeder einzelnen Proteinprobe wurden in $150 \mu 1$ sterilem Wasser verdünnt und mit einem Vortexer gemischt. Zudem wurde eine Kupfer-Lösung angefertigt (100 Teile 2\% $\mathrm{Na}_{2} \mathrm{CO}_{3}, 1$ Teil $2 \% \mathrm{~K}-\mathrm{Na}$-Tatrat, 1 Teil $\left.1 \% \mathrm{CuSO}_{4}\right)$. Zu der Verdünnungsreihe aus Albuminstandard und jeder Proteinprobe wurden langsam je $1 \mathrm{ml}$ von der Kupferlösung pipettiert und gemischt. Nach einer Inkubationszeit von 15 min bei Raumtemperatur wurde zu jedem Reaktionsgefäß $100 \mu$ l Folin-Ciocalteu-Phenol-Reagenz hinzugefügt und sofort gevortext. 45 min nach Hinzufügen der Kupferlösung konnte bei 562 nm die Absorption an dem Platereader (Bio Tek) gemessen werden. 
Nach folgender Rechnung konnte die Konzentration bestimmt werden:

$$
c=\frac{\text { Mittelwert der Proteinmenge }(\mu g)}{\text { eingesetzte Proteinmenge }(\mu l)}
$$

\subsubsection{Polyacrylamid-Gelelektrophorese (SDS-Page) für Western Blots}

Im Rahmen dieser Arbeit wurde das Nachweisverfahren von Proteinen nach Laemmli (Laemmli 1970) verwendet.

Zunächst wurde ein 12\%iges Trenngel (siehe Tabelle 8) hergestellt. Dieses wurde in eine Vorrichtung aus zwei Glasplatten mit einem Abstand von 1,5 mm gegossen. Eine anschließende Schicht Isopropanol ermöglichte eine glatte Oberfläche. Nach Polymerisierung des Trenngels wurde das Isopropanol entfernt und das Sammelgel (siehe Tabelle 9) angefertigt. Das Sammelgel wurde auf das Trenngel pipettiert und sofort ein Kamm für die Taschen aufgesetzt.

Tabelle 8: Mengenangaben für das $12 \%$ ige Trenngel aus Polyacrylamid

\begin{tabular}{|l|l|}
\hline Komponente & Volumen \\
\hline $30 \%$ Acrylamid & $7,5 \mathrm{ml}$ \\
\hline Lower Buffer $\mathrm{pH} 8,8$ & $4,9 \mathrm{ml}$ \\
\hline Aqua bidest. & $6,6 \mathrm{ml}$ \\
\hline $10 \%$ APS & $62,5 \mu \mathrm{l}$ \\
\hline TEMED & $15 \mu \mathrm{l}$ \\
\hline
\end{tabular}

Tabelle 9: Mengenangaben für das Sammelgel für den Western Blot

\begin{tabular}{|l|l|}
\hline Komponente & Volumen \\
\hline $30 \%$ Acrylamid & $0,65 \mathrm{ml}$ \\
\hline Upper Buffer $\mathrm{pH} 6,8$ & $1,25 \mathrm{ml}$ \\
\hline Aqua bidest. & $3,05 \mathrm{ml}$ \\
\hline $10 \%$ APS & $25 \mu 1$ \\
\hline TEMED & $5 \mu 1$ \\
\hline
\end{tabular}

Die zuvor denaturierten Proteine wurden jeweils zu $45 \mu \mathrm{g}$ in die einzelnen Taschen aufgetragen. Die mit SDS beladenen Proteine sind negativ geladen. Die Auftrennung erfolgte nach der Größe. Ein Größen-Marker (Page Ruler von Thermo Scientific), ein Proteingemisch mit definierten Größen, wurde zusätzlich aufgetragen. Die Kammer wurde mit Laufpuffer gefüllt. Bei $150 \mathrm{~V}$ wurde die Auftrennung der Proteine gestartet. 


\subsubsection{Polyacrylamid-Gelelektrophorese (SDS-Page) für Zymographie}

Das Sammel- und das Trenngel für die Zymographie wurden nach folgendem Pipettierschema hergestellt (genauere Details zur Herstellung sind bereits unter 2.2.3.4 beschrieben):

Tabelle 10: Mengenangaben für das 7,5\% ige Trenngel aus Polyacrylamid

\begin{tabular}{|l|l|}
\hline Komponente & Volumen \\
\hline $30 \%$ Acrylamid & $2 \mathrm{ml}$ \\
\hline Lower Buffer $\mathrm{pH} 8,8$ & $2 \mathrm{ml}$ \\
\hline Aqua bidest. & $2 \mathrm{ml}$ \\
\hline $10 \%$ APS & $80 \mu \mathrm{l}$ \\
\hline TEMED & $10 \mu \mathrm{l}$ \\
\hline Gelatine $(4 \mathrm{mg} / \mathrm{ml})$ & $2 \mathrm{ml}$ \\
\hline SDS $(10 \%)$ & $80 \mu \mathrm{l}$ \\
\hline
\end{tabular}

Tabelle 11: Mengenangaben für das Sammelgel für die Zymographie

\begin{tabular}{|l|l|}
\hline Komponente & Volumen \\
\hline $30 \%$ Acrylamid & $670 \mu \mathrm{l}$ \\
\hline Upper Buffer $\mathrm{pH} 6,8$ & $1,25 \mathrm{ml}$ \\
\hline Aqua bidest. & $3,075 \mathrm{ml}$ \\
\hline $10 \%$ APS & $50 \mu \mathrm{l}$ \\
\hline TEMED & $10 \mu \mathrm{l}$ \\
\hline SDS $(10 \%)$ & $50 \mu \mathrm{l}$ \\
\hline
\end{tabular}

Bevor die Proben für die Zymographie auf das Gel geladen worden waren, musste zu jedem Proteingemisch jeweils ein Viertel Non-reducing-buffer (5X) hinzugefügt werden. Auf das Gel wurden dann je $2 \mu \mathrm{g}$ Medium, $20 \mu \mathrm{g}$ U87-MG-Zellen und ein Marker aufgetragen. Anschließend wurden die Proteine bei $150 \mathrm{~V}$ elektrophoretisch aufgetrennt.

\subsubsection{Western-Blot-Transfermethode}

Es folgte das Blotting auf eine Nitrozellulose-Membran. Dazu wurden eine Membran und zwei Filterpapiere in der Größe des Gels ausgeschnitten. In folgender Reihenfolge wurde das Blottingsystem in einer von Bio-Rad hergestellten Kassette zusammengesetzt: Pad, Filterpapier, Nitrozellulose-Membran, Polyacrylamidgel, Filterpapier, Pad (von der Anode zur Kathode). Eine Spannung von 30 V für 90 min transferierte die Proteine von dem Gel auf die Nitrozellulose-Membran unter Verwendung eines geeigneten Transferpuffers. 
Eine kurze Färbung der Membran mit Ponceau-S ermöglichte eine Beurteilung der Qualität des Transfers.

\subsubsection{Immundetektion}

Die Membran wurde mit 5 \%iger Milch für $1 \mathrm{~h}$ geblockt. Diese Blockierung verhinderte, dass unerwünschte Proteine an der Membran binden konnten. Die Inkubation des primären Antikörpers (1:1000 verdünnt in der 5\%igen Milch) erfolgte über Nacht bei $4{ }^{\circ} \mathrm{C}$ auf einem Schüttelsystem.

Es folgten fünf Waschschritte der Membran mit TBST für je 5 min. Die Inkubation des sekundären Antikörpers für $1 \mathrm{~h}$ wurde bei Raumtemperatur durchgeführt. Der sekundäre Antikörper lag in einer Konzentration von 1:2000 in der 5 \%igen Milchlösung vor. An diesem Antikörper war eine Meerrettich-Peroxidase (HRP) gebunden. Die Peroxidase war für die anschließende Detektion mittels Chemilumineszenz wichtig. Es wurde eine 1:1 Lösung aus dem Kit „Western Lightning Ultra“ (Perkin Elmer) hergestellt. Die Membran wurde mit dieser Lösung für 5 min inkubiert. Die Meerretich-Peroxidase katalysierte in Gegenwart von Wasserstoffperoxid die Oxidation von Luminol. Der angeregte Zustand des Luminols ermöglichte die Emission im Bereich des blauen Lichtspektrums. Bevor mit der Detektion begonnen werden konnte, musste der Marker mit einem speziellen Stift (Glow Writer, Diversified Biotech) nachgezeichnet werden. Bei 425 nm wurden die Aufnahmen mit dem Molecular Imager Chemi Doc XRS+ (Biorad) angefertigt.

Anschließend wurde die Membran für $1 \mathrm{~h}$ mit einem Stripping Buffer bei Raumtemperatur inkubiert. Dabei wurde der erste Antikörper entfernt, indem durch ß-Mercaptoethanol die Disulfidbrücken der Proteine zu Thiolen reduziert wurden. Es folgten Waschschritte mit TBST und eine erneute Blockierung mit 5\%iger Milch für $1 \mathrm{~h}$. Danach konnte die Membran mit dem Housekeeper B-Actin, erneut ein primärer Antikörper, über Nacht bei $4{ }^{\circ} \mathrm{C}$ auf einem Schüttler inkubiert werden. Nach mehreren Waschschritten mit TBST wurde die Membran mit dem sekundären Antikörper für $1 \mathrm{~h}$ inkubiert. Es folgten die Schritte der Detektion, die bereits oben erläutert worden sind.

\subsubsection{Gelatin-Zymographie}

Die Gelatin-Zymographie ist eine Methode, um die Aktivität von Gelatinasen, in diesem Fall von den Matrix Metalloproteasen (MMPs) 2 und 9, zu überprüfen. In dem SDS-Gel befindet sich Gelatine. Während der elektrophoretischen Auftrennung und den anschlieBenden Schritten bauen die aktiven Metalloproteasen die Gelatine ab. 
Nach der Auftrennung wurde das Gel zunächst zweimal im Washing Buffer für je 30 min von den SDS-Resten befreit. Anschließend wurde es für $15 \mathrm{~min}$ im $37^{\circ} \mathrm{C}$ warmen Incubation Buffer gelegt. Nach der 30-minütigen Färbung in der Staining Solution, die Coomassie Blau enthält, wurde das Gel mit destilliertem Wasser und Destaining Solution gereinigt.

Nun konnten Aufnahmen von dem Gel mithilfe des Molecular Imager Chemi Doc XRS+ angefertigt werden.

\subsubsection{Real-Time-PCR}

Bei der sogenannten Real-Time-PCR kann die Amplifikation eines bestimmten Zielgens in Echtzeit verfolgt werden. Es wird ebenfalls eine Aussage über die Ausgangsmenge des entstandenen Produktes möglich. Verschiedene Methoden stehen dafür zur Verfügung. In dieser Arbeit wurde SybrGreen verwendet. Es handelt sich dabei um einen fluoreszierenden Farbstoff, der unspezifisch an doppelsträngige DNA bindet. Durch die Anregung bei $498 \mathrm{~nm}$ emittiert SybrGreen Licht bei einer Wellenlänge von $522 \mathrm{~nm}$. Während der Polymerase-Ketten-Reaktion reichert sich der Farbstoff durch die Entstehung der doppelsträngigen PCR-Produkte an. Das Signal ist somit proportional zur Menge des amplifizierten Genproduktes. Diese Quantifizierung findet nur in der exponentiellen Phase der PCR statt.

\subsubsection{RNA-Extraktion}

Für den Versuch der Tansfektion mit pEGFP-N1/pEGFP-N1-Arlts1 wurden die Zellen für die RNA Präparation $24 \mathrm{~h}$ nach der Transfektion extrahiert. Bei dem Ansatz mit pcDNA4/pcDNA4-CRABP2 wurden für den Basiswert die Zellen kurz vor der Transfektion geerntet. Dann folgten die Zeitpunkte $3 \mathrm{~h}, 5 \mathrm{~h}$ und $24 \mathrm{~h}$ nach Transfektion. Das Medium wurde vollständig von jedem Well entfernt und einmal mit gekühltem PBS gewaschen. $700 \mu \mathrm{l}$ QIAzol Lysis Reagent (Qiagen) wurden auf jede Kondition pipettiert und mit einem Zellkratzer die adhärenten Zellen vom Boden der 6-Well-Platte abgelöst. Das QIAzol enthält Phenol und Guanidiniumthiocyanat. Letzteres denaturiert Proteine und inaktiviert damit auch RNAsen. Die Zellen wurden mit dem QIAzol in ein Reaktionsgefäß überführt und konnten bei $-80{ }^{\circ} \mathrm{C}$ aufbewahrt werden. 


\subsubsection{RNA-Isolierung}

Die Isolierung der RNA wurde mithilfe eines miRNeasy® Mini Kit (Qiagen) durchgeführt. Der Prozess basiert auf der Phenol-Chloroform-Extraktion und der anschließende Fällung mit Ethanol.

Das bereits mit QIAzol versetzte Zellgemisch wurde auf Eis aufgetaut und mit $140 \mu 1$ Chloroform versetzt. Die RNA musste sofort für $15 \mathrm{~s}$ mit einem Vortexer gemischt und für 3 min bei Raumtemperatur aufbewahrt werden. Es wurde für 15 min bei $12000 \mathrm{rpm}$ zentrifugiert. Aufgrund unterschiedlicher Löslichkeit befanden sich RNA, DNA und Proteine in unterschiedlichen Phasen. Die RNA sammelte sich in der oberen wässrigen Phase an. Der Überstand wurde vorsichtig aus der oberen Phase pipettiert und in ein Reaktionsgefäß überführt. Es wurde das 1,5-fache Volumen Ethanol hinzugefügt und sehr gut vermischt. Das Gemisch wurde auf eine Silica-Säule pipettiert und bei $8000 \mathrm{rpm}$ für $15 \mathrm{~s}$ zentrifugiert. Die RNA war nun an die Membran der Säule gebunden. Ein Waschschritt mit $700 \mu 1$ RWT-Puffer und zwei Waschschritte mit je $500 \mu 1$ RPE-Puffer dienten der Reinigung der Säule. Danach wurde die Säule auf ein sauberes Reaktionsgefäß gesetzt, die RNA in $30 \mu 1$ RNAse-freiem Wasser eluiert und auf Eis gestellt.

Anschließend wurde die Konzentration der RNA photometrisch gemessen (Eppendorf BioPhotometer plus). Dazu wurde eine Verdünnung von 1:25 mit destilliertem Wasser in einer Küvette hergestellt.

\subsubsection{Herstellen von cDNA}

Dazu musste die RNA auf eine einheitliche Konzentration von $100 \mathrm{ng} / \mu 1 \mathrm{mit}$ RNAsefreiem Wasser verdünnt werden. Von der verdünnten RNA wurde $1 \mu \mathrm{g}$ für die Herstellung der cDNA verwendet. Das Protokoll ist unter 2.2.1.1 beschrieben.

\subsubsection{Quantitative PCR}

Die cDNA wurde von $100 \mathrm{ng} / \mu \mathrm{l}$ auf eine Konzentration von $20 \mathrm{ng} / \mu \mathrm{l}$ mit destilliertem Wasser verdünnt. Das iQ SybrGreen (Biorad) enthielt bereits Puffer, DNA-Polymerase, dNTPs und den SybrGreen-Farbstoff. Für den Master Mix wurde folgendes Protokoll verwendet:

Tabelle 12: Pipettierschema der qPCR für eine Probe

\begin{tabular}{|l|l|l|}
\hline Komponente & Konzentration & Volumen \\
\hline iQ SybrGreen (Biorad) & - & $5 \mu 1$ \\
\hline Steriles Wasser & - & $1 \mu \mathrm{l}$ \\
\hline Primer forward & $10 \mathrm{pmol} / \mu \mathrm{l}$ & $0,1 \mu \mathrm{l}$ \\
\hline Primer reverse & $10 \mathrm{pmol} / \mu \mathrm{l}$ & $0,1 \mu \mathrm{l}$ \\
\hline
\end{tabular}


Es wurde eine 384-Well-Platte verwendet. Zunächst wurden pro Well $8 \mu 1$ des jeweiligen Master Mixes pipettiert und anschließend kurz zentrifugiert. Von der cDNA (20 ng/ $\mu \mathrm{l})$ wurden pro Well $2 \mu$ l hinzugefügt und die Platte dann erneut zentrifugiert. Die Platte wurde mit einer Folie eingedeckt und die qPCR konnte am Light Cycler (CFX384 Touch Real-Time PCR Detection System, Biorad) nach folgendem Programm ablaufen:

Tabelle 13: Temperaturprofil der qPCR

\begin{tabular}{|l|l|}
\hline Schritt & Zeit \\
\hline Equilibration & $50^{\circ} \mathrm{C}, 2 \mathrm{~min}$ \\
\hline Denaturierung & $95^{\circ} \mathrm{C}, 5 \mathrm{~min}$ \\
\hline Denaturierung & $95^{\circ} \mathrm{C}, 15 \mathrm{~s}$ \\
\hline Annealing & $60^{\circ} \mathrm{C}, 30 \mathrm{~s}$ \\
\hline Elongation & $72^{\circ} \mathrm{C}, 30 \mathrm{~s}$ \\
\hline
\end{tabular}

Zum Ende der PCR wurde eine sogenannte Schmelzkurve von $65{ }^{\circ} \mathrm{C}-95{ }^{\circ} \mathrm{C}$ mit einer Temperaturerhöhung von $0,5^{\circ} \mathrm{C}$ pro $0,05 \mathrm{~s}$ angefertigt.

Bei der Auswertung wurde in dieser Arbeit auf zwei sogenannte Housekeeper normalisiert. Dabei handelt es sich um Gene, welche in unserem Fall nahezu keiner Regulation unterliegen, Hypoxanthin-Phosphoribosyl-Transferase 1 (HPRT1) und Hydroxymethylbilan-Synthase (HMBS). Damit werden Schwankungen aus den voran gegangenen Schritten, der RNA-Isolierung und des Anfertigens von cDNA, mit einbezogen.

\subsubsection{Färbung für konfokale Mikroskopie}

Das Medium wurde aus den Wells der 24-Well-Platte entfernt und die Zellen mit PBS gewaschen. Die Zellen mussten zunächst auf dem Deckgläschen mit 4\%igem Formaldehyd für 20 min fixiert werden. Bei diesem Vorgang werden die Zellen in ihrer morphologischen Struktur fixiert. Die Zellen sterben bei dem Fixierungsvorgang ab, was die Voraussetzung für eine erfolgreiche Färbung mit DAPI ist, da es nur in tote Zellen mit einer defekten Zellmembran eindringen kann. Es folgten drei Waschschritte mit PBS. Es wurden $50 \mu$ l DAPI ( $1 \mathrm{mg} / \mathrm{ml})$ aufgetragen, für $5 \mathrm{~min}$ bei Raumtemperatur inkubiert, und erneut mit PBS gewaschen. Die Glasplättchen wurden mit einer Pinzette aus dem Well entnommen und bei Raumtemperatur getrocknet. Anschließend wurden sie auf einem Objektträger (Superfrost Plus von Menzel GmbH) mit AquaPolyMount eingedeckt. DAPI interkaliert mit der doppelsträngigen DNA, sodass mit dieser Färbung der Zellkern nachgewiesen werden konnte. 


\subsubsection{Zelltod-Assay}

\subsubsection{Färbung der Zellen}

Zur Bestimmung des Zelltods durch Apoptose und Nekrose wurden die U87-MGGlioblastomzellen mit Annexin-V (Nachweis von Apoptose) und Propidiumiodid (Nachweis von Apoptose/Nekrose) gefärbt und anschließend mit einem Durchflusszytometer detektiert. Für diesen Assay wurden ebenfalls 300000 Zellen pro Well in einer 6-WellPlatte ausgesät und nach $24 \mathrm{~h}$ transfiziert (siehe 2.2.2).

Das Medium wurde $24 \mathrm{~h}$ nach der Transfektion vollständig entfernt. Es wurden 0,5 ml Trypsin pro Well hinzugefügt und für $3 \mathrm{~min}$ im Zellinkubator bei $37{ }^{\circ} \mathrm{C}$ inkubiert. Nach der Inaktivierung des Trypsins mit $1 \mathrm{ml}$ MEM+FCS wurden die Zellen für 5 min bei 1200 rpm zentrifugiert. Der Überstand wurde entfernt und das Pellet in $1 \mathrm{ml}$ sterilen PBS gewaschen. Aus dieser Zellsuspension wurde die Zellzahl ermittelt. Die gesamte Zellsuspension wurde erneut zentrifugiert. Dann wurde das Pellet mit Annexin-V-Binding Buffer (Bio Legend) in der entsprechend berechneten Menge resuspendiert, um eine Konzentration von $1 \times 10^{6} / \mathrm{ml}$ Zellen zu erreichen.

$100 \mu 1$ dieser Suspension mit 1x10\% mlZellen wurden in ein für die Durchflusszytometrie geeignetes Reaktionsgefäß überführt. Es wurde eine Doppelbestimmung für jede Bedingung angefertigt. Als Kontrollen für die Durchflusszytometrie wurden GFP negative U87-MG-Zellen mit Annexin-V und Propidiumiodid separat gefärbt. Für die Doppelbestimmungen jeder Kondition wurde auf die $100 \mu$ l Zellsuspension je $5 \mu$ l Annexin-VAPC (Allophycocyanin) und $10 \mu 1$ Propidiumiodid $(0,5 \mathrm{mg} / \mathrm{ml})$ pipettiert und vorsichtig gevortext. Die Färbung wurde für 15 min im Dunkeln inkubiert. Anschließend wurden $400 \mu 1$ Annexin-V Binding Buffer zu jedem Reaktionsgefäß hinzugefügt. Die Detektion am Durchflusszytometer musste sofort erfolgen, damit die Fluoreszenzfarbstoffe nicht an Intensität verloren.

\subsubsection{Durchflusszytometrie}

Das Durchflusszytometer (BD FACS Canto II) besteht aus einer Durchflussmesszelle. In dieser wird durch eine Mikrokanalküvette die Zellsuspension aufgesaugt. Die Mikrokanalküvette verjüngt sich und ermöglicht, dass jede Zelle einzeln durch einen dünnen Strahl geleitet wird. Als Lichtquelle wird in diesem Fall ein Laser verwendet. Filter trennen die Signale der unterschiedlichen Fluoreszenzfarbstoffe auf und Detektoren können diese Signale verstärken. Ein Computer verrechnet dabei die Informationen. 
Bei der Durchflusszytometrie wird das Vorwärtsstreulicht (Forward Scatter) der einzelnen Zellen bestimmt. Dieses gibt Rückschlüsse auf das Volumen einer Zelle. Das Seitwärtsstreulicht (Side Scatter) detektiert die Granularität der Zelle. In diesem Assay wurde das Vorwärts- und Seitwärtsstreulicht zunächst verwendet, um Zelltrümmer und verklumpte Zellhaufen aus der Berechnung auszuschließen. Die eigentliche Messung erfolgte dann mittels der Fluoreszenzfarbstoffe der Zellen. Insgesamt wurden bei diesem Assay 10000 Zellen pro Bestimmung gemessen.

Es wurden die U87-MG-Zellen betrachtet, die GFP exprimieren. Das Absorptionsmaximum für GFP liegt bei $509 \mathrm{~nm}$.

Annexin-V färbt Zellen in der frühen Apoptose. Das Absorptionsmaximum des mit APC markierten Annexin-V liegt bei $650 \mathrm{~nm}$. Propidiumiodid färbt Zellen in der späten Apoptose und Nekrose. Das Absorptionsmaximum von Propidiumiodid an der DNA interkalierend liegt bei $535 \mathrm{~nm}$.

Lebende Zellen sind Annexin-V- und Propidiumiodid-negativ. Früh apoptotische Zellen sind ausschließlich Annexin-V positiv. Zellen, die bereits nekrotisch sind, lassen sich mit Annexin-V und Propidiumiodid anfärben.

\subsubsection{Migrations-Assay}

Mittels einer kontinuierlichen Impedanzmessung einer Variante einer BoydenChamber wurde die Migration der transfizierten U87-MG-Zellen über 4,5 h getestet.

Für diesen Assay wurden ebenfalls 300000 Zellen pro Well in einer 6-Well-Platte ausgesät und nach $24 \mathrm{~h}$ transfiziert (siehe 2.2.2). Nach weiteren $24 \mathrm{~h}$ konnten die Zellen für den Migrationsassay vorbereitet werden. Zunächst wurde das Medium vollständig entfernt und die U87-MG-Zellen mit $1 \mathrm{ml}$ 0,05\% Trypsin-EDTA pro Well vom Plattenboden gelöst. Nach dreiminütiger Inkubation bei $37^{\circ} \mathrm{C}$ wurde mit $2 \mathrm{ml}$ MEM+FCS neutralisiert. Die Zellsuspension wurde in einem Falcon Tube gesammelt und bei $1200 \mathrm{rpm}$ für 3 min zentrifugiert. Nach vollständigem Absaugen des Überstandes wurde das Pellet in $1 \mathrm{ml}$ kaltem PBS+1\% Bovines Serumalbumin (BSA) resuspendiert. Die Zellsuspension wurde in ein für das Fluorescence-activated cell sorting (FACS)-Gerät geeignetes Röhrchen überführt und auf Eis gestellt.

Das FACS-Gerät (BD FACS AriaII) bestimmt wie das unter 2.2.6.2 beschriebene Durchflusszytometer nicht nur die Menge an fluoreszierenden Zellen, sondern kann diese Zellen auch sortiert nach Fluoreszenzfarbstoff sammeln. Durch Vibration werden die Zellen im 
Gerät vereinzelt, elektrisch geladen und entsprechend ihrer Ladung anschließend getrennt. Für diese Arbeit wurden GFP-positive von GFP-negativen Zellen separiert und anschließend gesammelt.

Nach der Sortierung wurden die Zellen für 3 min bei $1200 \mathrm{rpm}$ zentrifugiert, in $1 \mathrm{ml}$ MEM ohne FCS resuspendiert und in einer Zählkammer nach Neubauer gezählt.

Die für den Assay verwendete Kammer (CIM-Plate 16, ACEA Bioscience) wurde wie folgt bestückt: in jede Kavität der unteren Kammer wurden zunächst $160 \mu 1 \mathrm{MEM+5 \%}$ FCS pipettiert. Die obere Kammer wurde entsprechend den Herstellerangaben auf die untere gesetzt und in jede Kavität $50 \mu 1$ MEM ohne FCS gegeben. Das gesamte System wurde für $1 \mathrm{~h}$ bei $37^{\circ} \mathrm{C}$ im sterilen Inkubator equilibriert. Im Anschluss daran wurden je Kondition $100 \mu \mathrm{l}$ mit 25000 Zellen in die obere Kammer pipettiert. Auf ein luftblasenfreies Pipettieren wurde bei jedem Schritt geachtet.

Die Abbildung 1 zeigt den schematischen Aufbau der CIM-Plate 16. In der oberen Kammer befinden sich zu Beginn die Zellen in FCS-freiem Medium. Um Nährstoffe zu bekommen, müssen die Zellen eine Membran mit $8 \mu \mathrm{m}$ großen Poren und eine Beschichtung mit Goldelektroden passieren, denn in der unteren Kammer liegt Medium mit 5\% FCS vor, das als Lockstoff fungiert. Die Migration über die Membran wird über 4,5 h im Inkubator anhand der veränderten Impedanz in Echtzeit gemessen (xCELLigence ${ }^{\circledR}$ RTCA DP Instrument). Jede durch die Poren migrierende Zelle erhöht den Widerstand. Der höchste Widerstand wird als Cell Index gemessen und angezeigt.

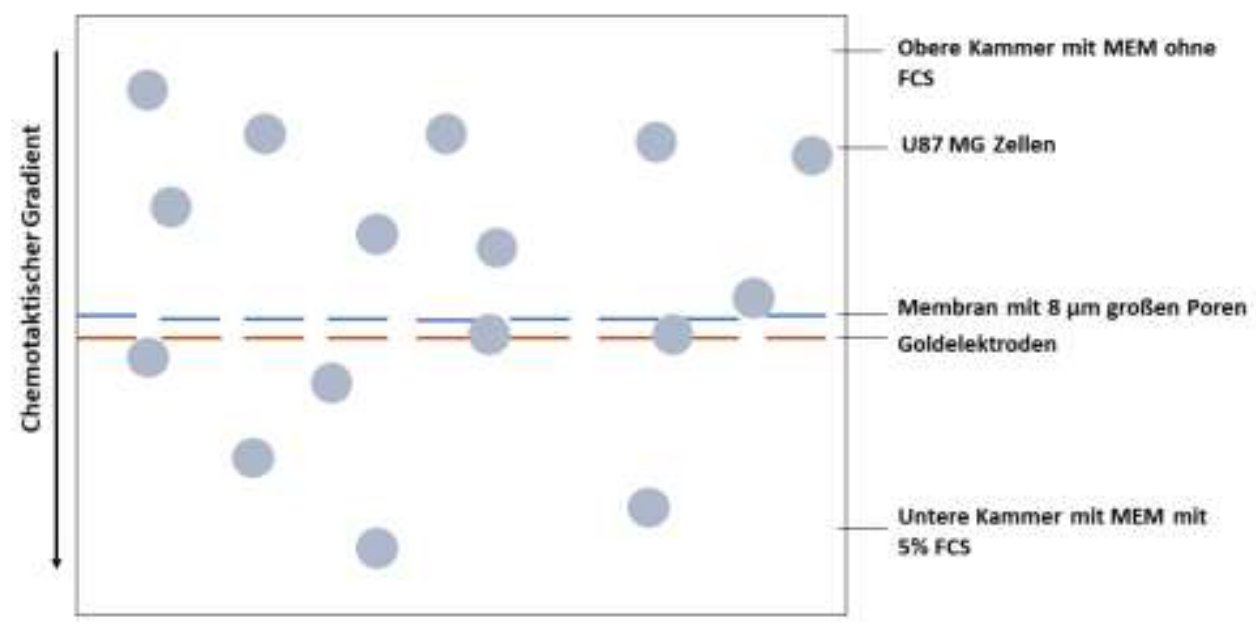

Abb. 1: Schematischer Aufbau einer CIM-Plate 16 (modifiziert nach xCelligence, ACEA Bioscience) 


\subsubsection{Statistik}

Die statistische Signifikanz wurde mittels t-Test erhoben und als p-Wert angegeben, wobei ein $p$-Wert $\leq 0,05$ als statistisch signifikant angesehen wird. Die mathematische Berechnung und die grafische Darstellung der Ergebnisse wurden mithilfe der Software Graph PadPrism 5 durchgeführt. Die erhobenen Daten wurden mittels Student's t-Test getestet.

Bei der Auswertung der Real Time PCRs wurde die relative mRNA des Kontrollvektors auf $100 \%$ gesetzt. Entsprechend einem Dreisatz wurde schließlich die Expression der Gene des untersuchten Plasmids (pEGFP-N1-Arlts1) ermittelt. 


\section{Ergebnisse}

\subsection{ARLTS1-mRNA wird durch CRABP2 stabilisiert}

Um zu untersuchen, ob die mRNA von ARLTS1 durch Cellular retinoic acid-binding protein 2 (CRABP2) stabilisiert wird, haben wir die relative mRNA Expression von ARLTS1 in U87-MG-Zellen gemessen. In dieser Arbeit wurde die Zelllinie U87 MG verwendet und in dieser die wildtyp-Variante von $C R A B P 2$ überexprimiert. Hierzu wurde CRABP2 in das Plasmid pcDNA4 kloniert (siehe 2.2.1) und das Plasmid pcDNA4/pcDNA4-CRABP2 transfiziert (siehe 2.2.2.3). Mittels Real Time PCR wurde die mRNA Expression gemessen (siehe 2.2.4). Hierdurch konnten wir zeigen, dass die mRNA von ARLTS1 durch die zusätzliche Expression von CRABP2 in Glioblastomzellen verstärkt exprimiert wird. In Abbildung 2 wird dieser signifikante Unterschied $(\mathrm{p}=0.0139) 24 \mathrm{~h}$ nach der Transfektion sichtbar. Wenn die U87-MG-Zellen CRABP2 überexprimieren, ist die relative mRNA-Expression von ARLTS1 zu diesem Zeitpunkt statistisch signifikant erhöht, verglichen mit der Kontrolle, in der U87-MG-Zellen mit dem Plasmid pcDNA4 transfiziert wurden.

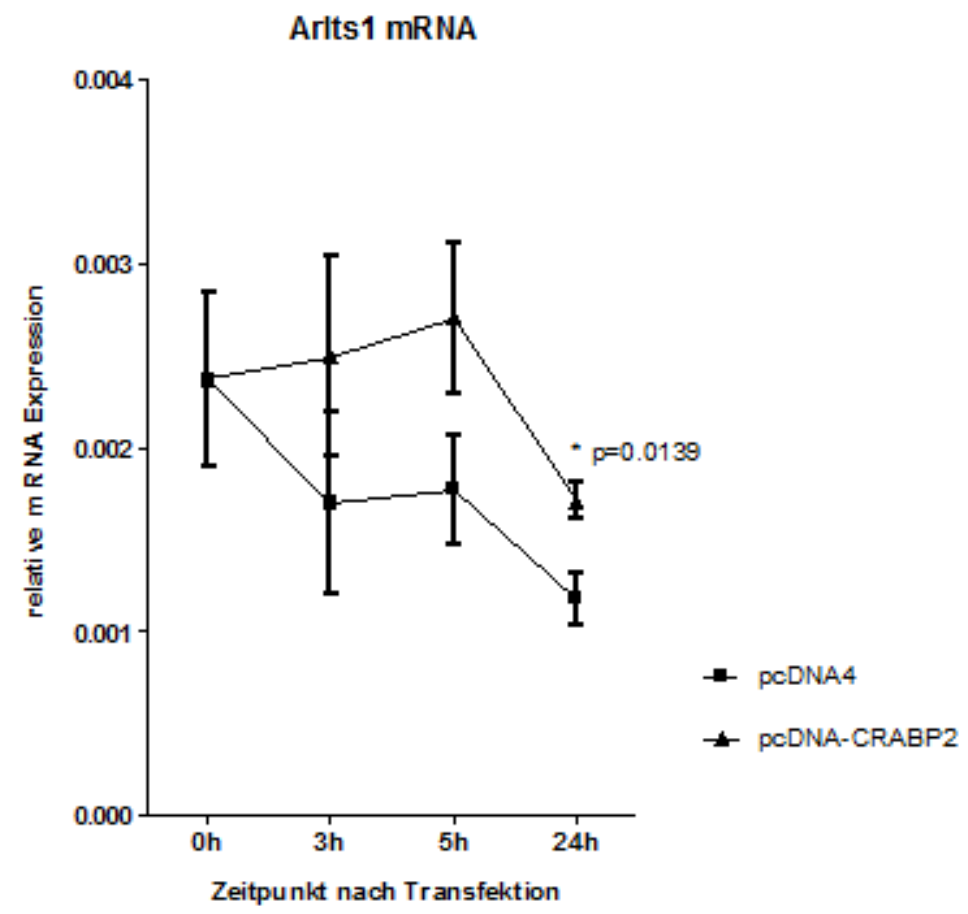

Abb. 2: Relative Expression von ARLTS1-mRNA in U87-MG-Zellen nach Transfektion mit pcDNA4 (Viereck) bzw. pcDNA4-CRABP2 (Dreieck); $0 \mathrm{~h}=$ vor der Transfektion, 3 h, 5 h und 24 h nach der Transfektion; n=6; Student's t-Test 


\subsection{Klonierung von pEGFP-N1-Arlts1}

Die Rolle von CRABP2 in GBM wurde bereits gezeigt. Die Tatsache, dass es unter anderem auch die mRNA von ARLTS1 stabilisiert, warf die Frage auf, ob und welche Rolle Arlts1 in GBM haben könnte.

Um diese Frage beantworten zu können, wurde zunächst das Plasmid pEGFP-N1-Arlts1 kloniert und U87-MG-Zellen hiermit transfiziert. Anschließend wurden die transfizierten U87-MG-Zellen hinsichtlich Apoptose, Nekrose und Migration untersucht. Abbildung 3 zeigt die Vektorkarte mit den entsprechenden Schnittstellen für die Restriktionsenzyme BamH1 und Kpn1, die für diese Arbeit für die Klonierung verwendet worden sind.

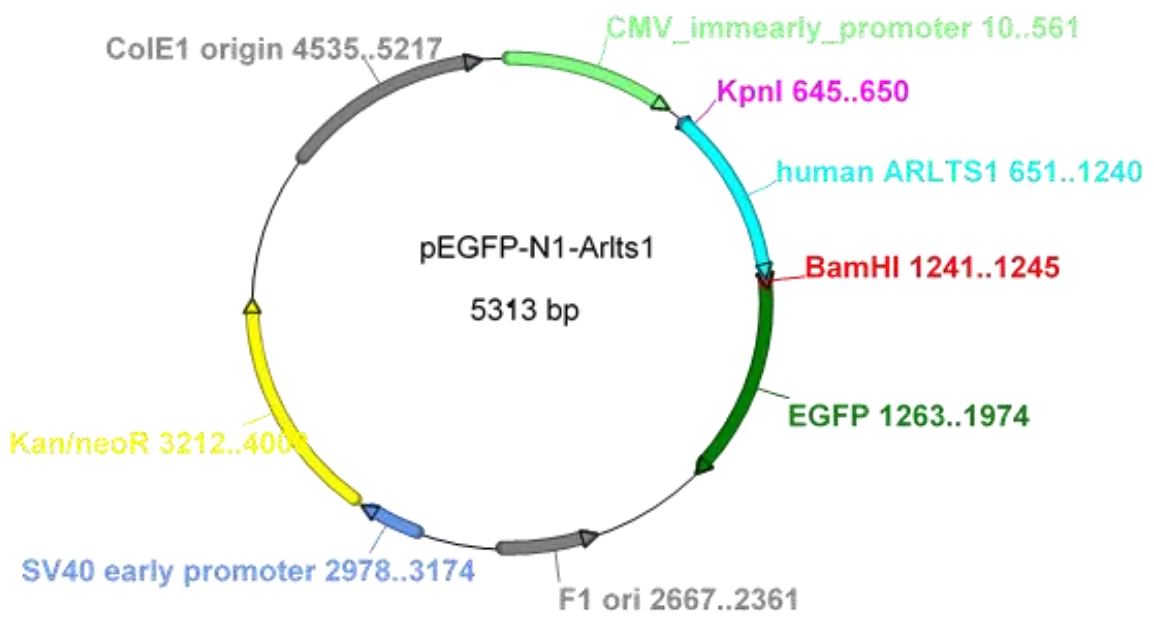

\section{Abb. 3: Vektorkarte für das Plasmid pEGFP-N1-Arlts1}

Eine Kolonie-PCR (siehe 2.2.1.9) mit spezifischen Primern für ARLTS1 (siehe Abbildung 4) zeigt ein PCR-Produkt von $601 \mathrm{~kb}$ für die Kolonien 1, 3, 4, 5 und 6. Diese Größe entspricht dem Insert ARLTS1. Die Sequenzanalyse ergab eine ARLTS1 entsprechende Sequenz. Da ARLTS1 ohne Stop-Codon in die MCS und in demselben Leseraster wie GFP kloniert wurde, ist es als Fusionsprotein zum N-Terminus von GFP exprimiert. 


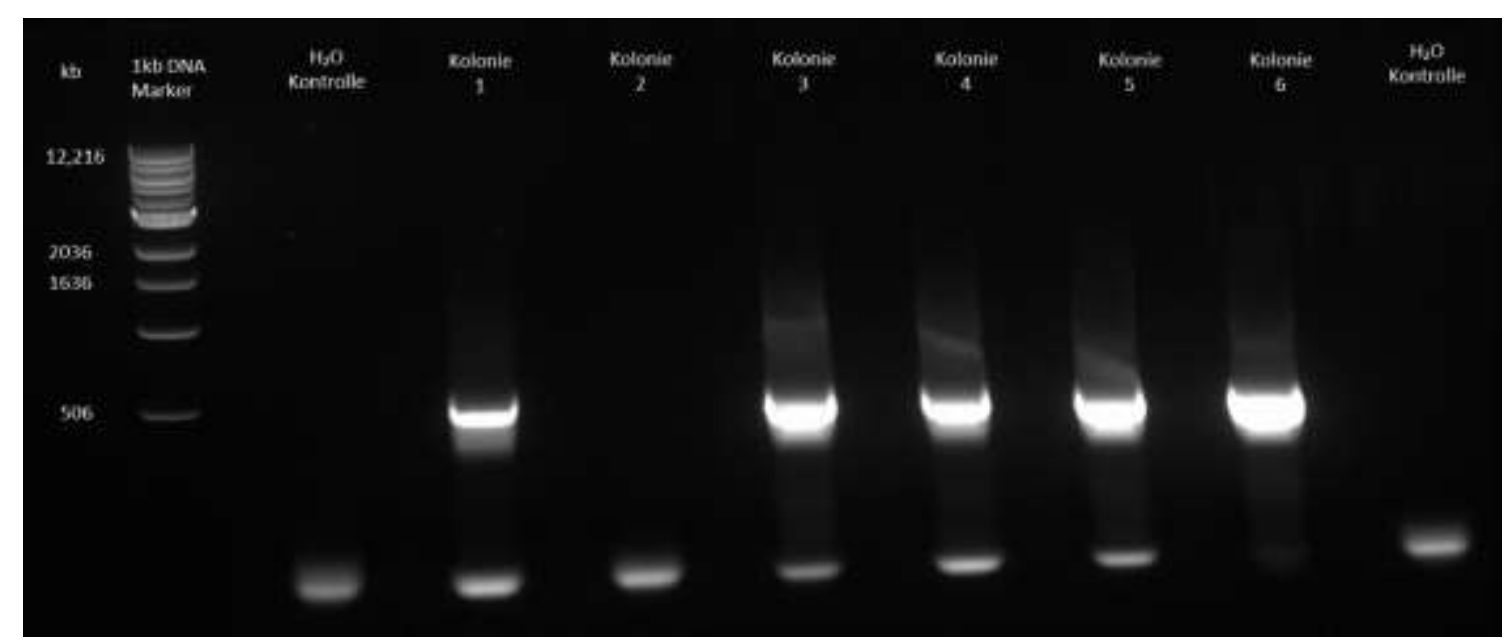

Abb. 4: Kolonie-PCR zur Kontrolle der Transformation des Plasmids pEGFP-N1Arlts1 in Xl-1 blue E. coli; Die Bande auf Höhe von 601 kb entspricht der Größe des Inserts ARLTS1; 1\% iges Agarose-Gel

\subsection{Expression von pEGFP-N1-Arlts1 in U87-MG-Zellen}

Im Anschluss an die Sequenzierung wurde das Plasmid pEGFP-N1-Arlts1 in die U87MG-Zellen transfiziert (siehe 2.2.2.3). Zur Kontrolle der Arlts1 Expression wurden Bilder mit dem konfokalen Mikroskop $24 \mathrm{~h}$ nach Transfektion angefertigt. Zellen, die ARLTS1 exprimieren, exprimieren ebenfalls GFP. Der grün fluoreszierende Farbstoff wird von erfolgreich transfizierten Zellen unter einem konfokalen Mikroskop erkennbar (siehe Abbildung 5). Die Sichtbarkeit von GFP und Fusionsproteinen, in diesem Fall Arlts1, werden durch Anregung eines Lasers mit der Wellenlänge von 488 nm ermöglicht. Die nach Färbung mit DAPI markierten Zellkerne (siehe 2.2.5) konnten mit einem Laserlicht mit einer Wellenlänge von $405 \mathrm{~nm}$ angeregt und die Bilder aufgenommen werden.

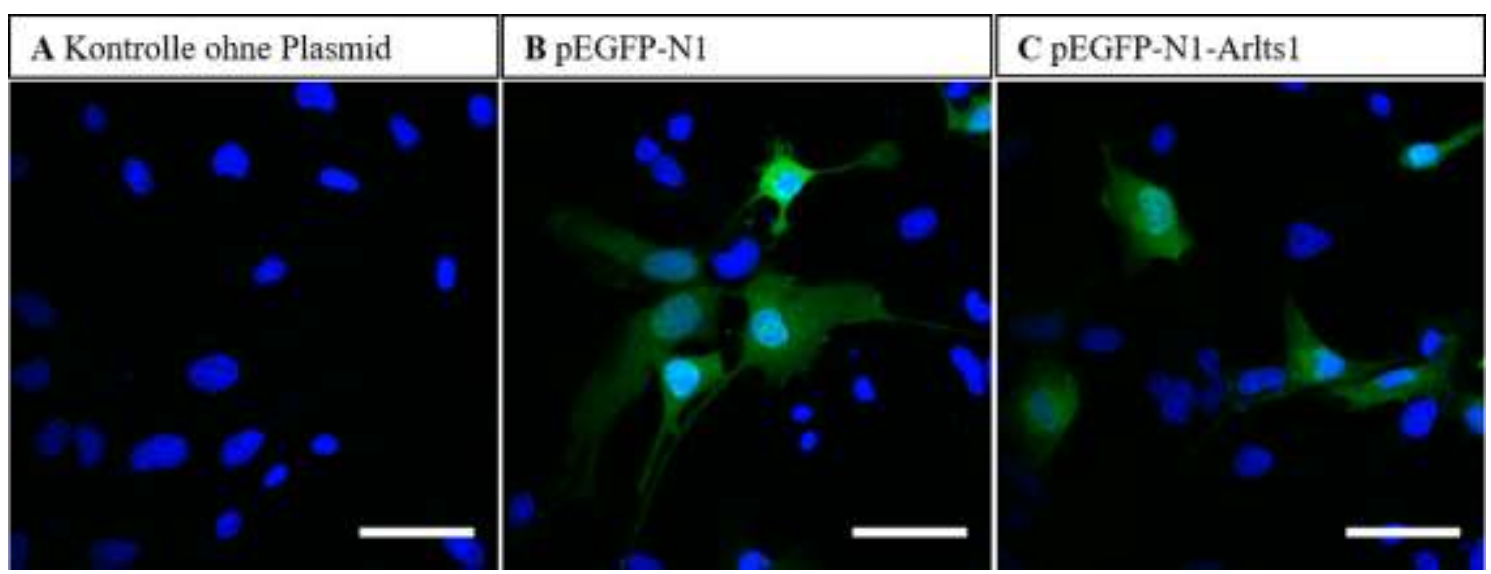

Abb. 5: Konfokale Mikroskopie der transfizierten U87-MG-Zellen; die Zellen wurden 24 h nach der Transfektion fixiert und die Zellkerne mit DAPI gefärbt; A: Kontrolle, U87-MG-Zellen B: U87-MG-Zellen mit pEGFP-N1 C: U87-MG-Zellen mit pEGFP-N1-Arlts1; Maßstab= $50 \mu \mathrm{m}$ 


\title{
3.4 Bestimmung der Transfektionseffizienz der U87-MG-Zellen mittels Durch- flusszytometrie
}

Um die Transfektionseffizienz zu ermitteln, wurde das Verfahren der Durchflusszytometrie verwendet. Zellen, welche das grün fluoreszierende Protein GFP exprimieren, exprimieren ebenfalls ARLTS1. Somit repräsentiert ein GFP positives Signal eine erfolgreiche Transfektion mit dem Plasmid pEGFP-N1-Arlts1. Die Messungen wurden 24 h nach der Transfektion durchgeführt (siehe 2.2.6.2).

Abbildung 6 zeigt, dass im Mittel 32\% der U87-MG-Zellen erfolgreich mit pEGFP-N1 und $28 \%$ der Zellen mit pEGFP-N1-Arlts1 transfiziert werden konnten.

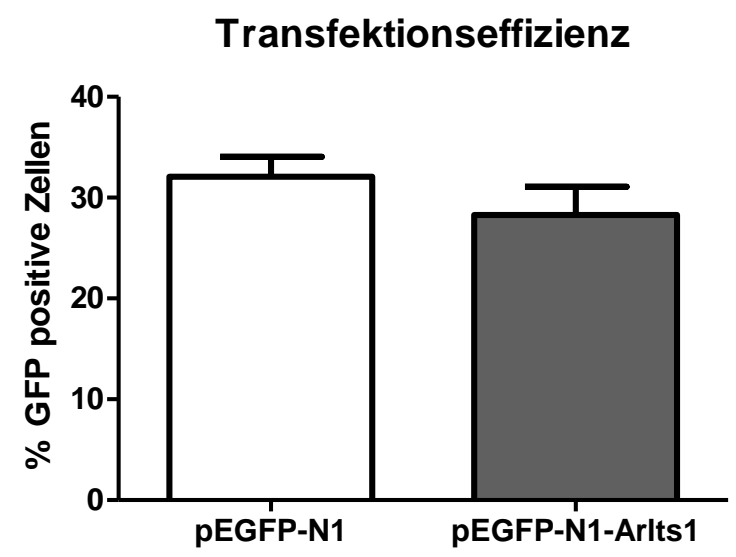

\begin{abstract}
Abb. 6: Ermittlung der Transfektionseffizienz mittels Durchflusszytometrie; U87MG-Zellen mit pEGFP-N1 (32\% transfizierte Zellen) bzw. pEGFP-N1-Arlts1 (28\% transfizierte Zellen); 24 h nach der Transfektion; $n=4$
\end{abstract}

\subsection{Zelltod-Analyse}

\subsubsection{Bestimmung der mRNA-Expression proapoptotischer Gene in ARLTS1 überexprimierenden U87-MG-Zellen}

Arlts1 ist in verschiedenen Tumoren als Tumorsuppressorgen bekannt. Für hirneigene Tumoren, wie das GBM, ist hierüber bislang nichts beschrieben. Der Einfluss einer Überexpression des Wildtyp-Arlts1 auf den programmierten Zelltod sollte im Folgenden untersucht werden.

Der programmierte Zelltod (Apoptose) wurde auf mRNA-Ebene mittels Real Time PCR überprüft. $24 \mathrm{~h}$ nach der Transfektion von U87-MG-Zellen mit pEGFP-N1/pEGFP-N1Arlts1 wurde die RNA extrahiert und mit den Primern Caspase 3, 7 bzw. 9 eine PCR durchgeführt (siehe 2.2.4.4). Diese Caspasen repräsentieren sowohl den intrinsischen als 
auch den extrinsischen Weg der Apoptose. Als Housekeeping-Gen wurde HMBS verwendet. Zur statistischen Auswertung wurde auf die relative mRNA Expression des Vektors pEGFP-N1 normalisiert.

Wie in Abbildung $7 \mathrm{zu}$ sehen, gibt es keinen signifikanten Unterschied in der mRNA Expression der Caspasen 3, 7 bzw. 9 zwischen den U87-MG-Zellen mit pEGFP-N1 bzw. mit pEGFP-N1-Arlts1 $24 \mathrm{~h}$ nach Transfektion.

Caspase 3 mRNA

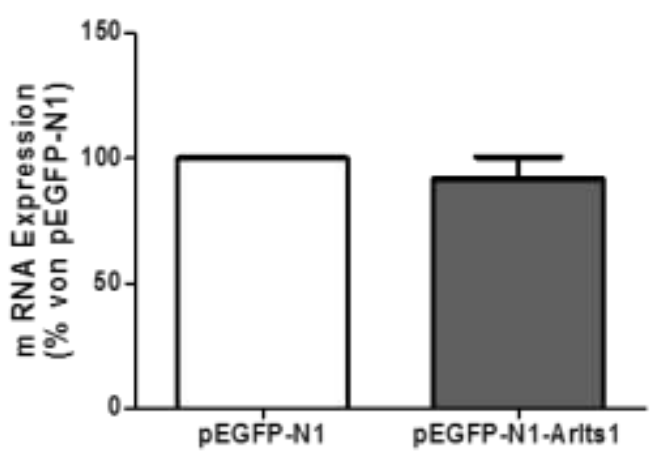

Caspase 7 mRNA

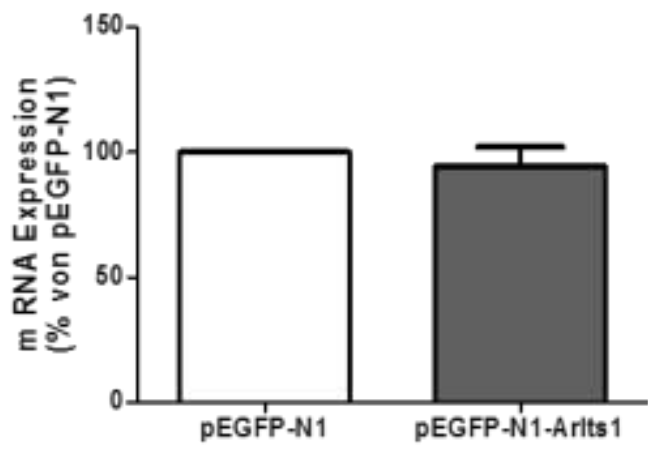

Caspase 9 mRNA

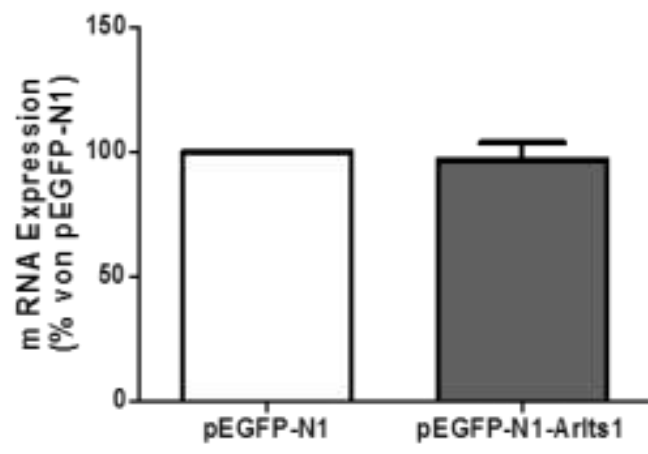

Abb. 7: Real-Time-PCR für Caspase 3, 7 und 9; kein statistisch signifikanter Unterschied zwischen U87-MG-Zellen mit pEGFP-N1 bzw. pEGFP-N1-Arlts in der relativen mRNA-Expression; 24 h nach Transfektion; n=6; Student's $t$-Test

\subsubsection{Zelltodanalyse von ARLTS1 überexprimierenden U87-MG-Zellen}

Da die Expression von Genen nicht notwendigerweise mit der Translation der Proteine korreliert, analysierten wir die apoptotische Aktivität auch auf Proteinebene. Die Quantifizierung apoptotischer und nekrotischer Zellen erfolgte mittels Durchflusszytometrie. Die U87-MG-Zellen wurden $24 \mathrm{~h}$ nach Transfektion mit Annexin V (APC-markiert) und Propidiumiodid gefärbt. Annexin V bindet an Zellen, die sich in einem frühen Stadium 
der Apoptose befinden, bei denen Phosphatidylserin an die Membranaußenseite gelangt und Annexin V so binden kann. Zellen, die sich bereits in einem spätapoptotischen bzw. nekrotischen Stadium befinden, lassen sich spezifisch mit Propidiumiodid und Annexin V färben. Das Propidiumiodid kann in den Zellkern eindringen, wenn die Zelle tot und die Zellmembran porös geworden ist. Die Abbildung 8 zeigt die grafische Darstellung der Resultate. Der Quadrant Q3-1 zeigte dabei die größte Population. Hier wurden GFP-positive Zellen abgebildet, die weder mit Annexin V noch mit Propidiumiodid angefärbt sind und somit die vitalen Zellen repräsentieren. Es wurde deutlich, dass insgesamt im Mittel nur 13\% der gemessenen Population apoptotisch oder nekrotisch waren.
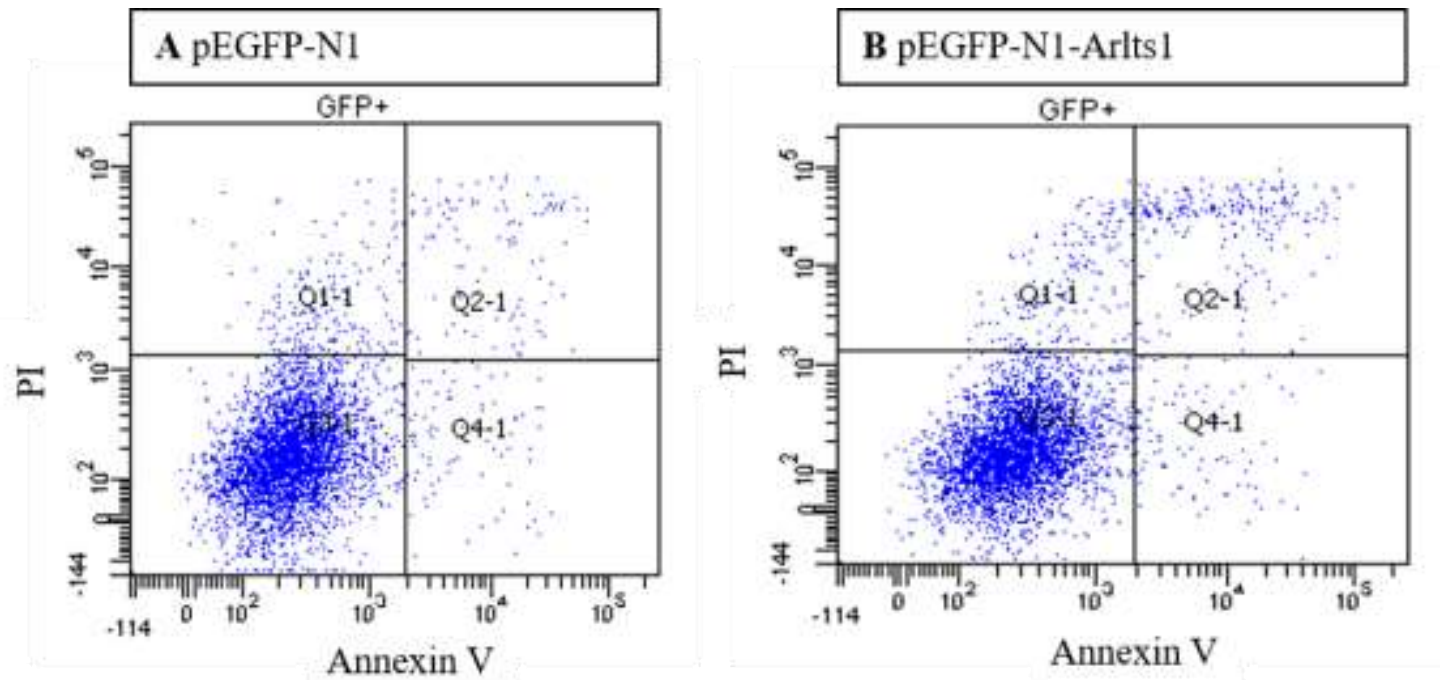

Abb. 8: Durchflusszytometrie; A) pEGFP-N1 transfizierte GFP+ U87-MG-Zellen B) pEGFP-N1-Arlts1 transfizierte GFP+ U87-MG-Zellen; Q1-1 PI positive Zellen, Q21 PI und Annexin V positive Zellen, Q3-1 PI und Annexin V negative Zellen, Q4-1 Annexin $V$ positive Zellen

Auch eine quantitative Auswertung der Ergebnisse der Durchflusszytometrie zeigte, dass es keinen signifikanten Unterschied bei dem nekrotischen bzw. späten apoptotischen Zelltod (siehe Abbildung 9, PI) gibt. Sowohl bei den U87-MG-Zellen mit pEGFP-N1 als auch bei den U87-MG-Zellen mit pEGFP-N1-Arlts1 starben im Durchschnitt etwa 6\% aller GFP-positiven Zellen. 
Auch bei der Überprüfung des frühen apoptotischen Zelltods mittels der Annexin V-Färbung gibt es keinen Unterschied zwischen den U87-MG-Zellen mit pEGFP-N1 bzw. pEGFP-N1-Arlts1 (siehe Abbildung 9, Annexin V). Bei beiden Konditionen sterben auf dem frühen apoptotischen Weg etwa 4\% der GFP-positiven Zellen.
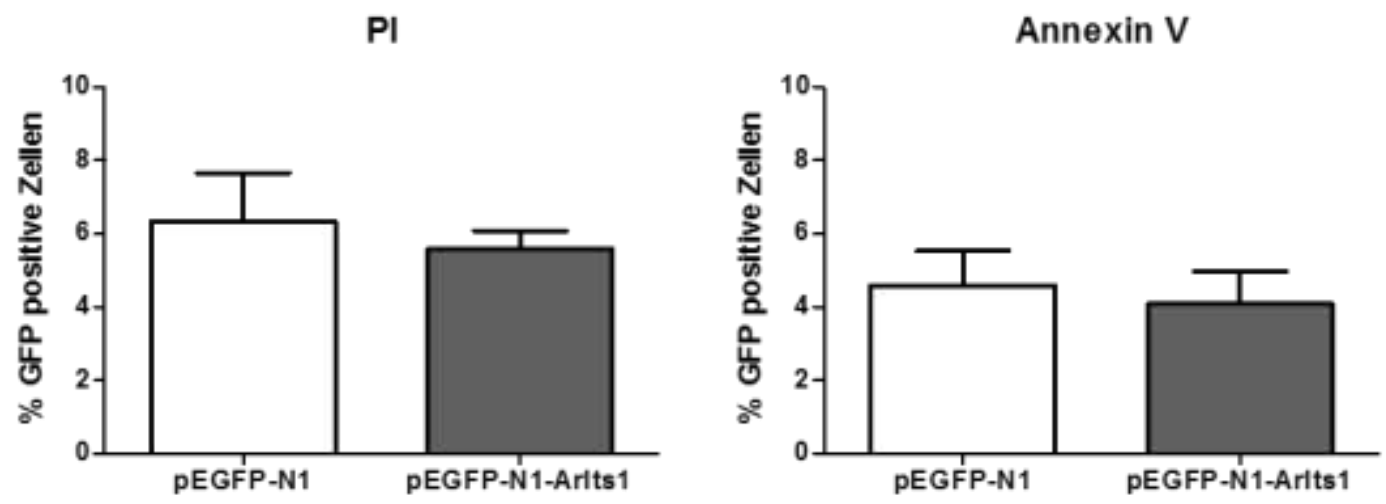

\begin{abstract}
Abb. 9: Durchflusszytometrie zur Überprüfung von Nekrose/später Apoptose (PI Färbung) und früher Apoptose (Annexin V-Färbung) in U87-MG-Zellen mit pEGFP-N1 bzw. pEGFP-N1-Arlts1; $24 \mathrm{~h}$ nach der Transfektion; $\mathrm{n=4}$
\end{abstract}

\title{
3.6 Analyse der mRNA-Expression von B-cell lymphoma 2 (BCL-2) in ARLTS1 überexprimierenden U87-MG-Zellen
}

Neben den pro-apoptotisch regulierenden Caspasen wurde auch die Expression des Zelltod-inhibierenden $B C L-2$ untersucht. Bcl-2 gehört zu der gleichnamigen Familie, die eine wichtige Rolle in der Regulation der Apoptose spielt.

24 h nach der Transfektion wurde die RNA der Glioblastomzellen extrahiert und spezifische Primer für den anti-apoptotischen Marker BCL-2 in einer Real Time PCR verwendet (siehe 2.2.4.). Es konnte ein signifikanter Unterschied $(\mathrm{p}=0.0128)$ zwischen den U87MG-Zellen mit pEGFP-N1 bzw. pEGFP-N1-Arlts1 gezeigt werden. Abbildung 10A zeigt eine Reduktion der relativen Expression der mRNA von BCL-2 in denjenigen U87-MGZellen, welche ARLTS1 überexprimieren.

Um zu überprüfen, ob sich die verminderte Expression von Bcl-2 auch auf der Proteinebene zeigen lässt, wurden Western Blots angefertigt (siehe 2.2.3). Das Protein wurde $24 \mathrm{~h}$ nach der Transfektion gesammelt. Das Protein Bcl-2 ist 26 kDa groß. Als Housekeeper-Protein wurde $\beta$-Actin mit einer Größe von $42 \mathrm{kDa}$ gewählt. Zu dem Zeitpunkt $24 \mathrm{~h}$ nach Transfektion konnte kein Unterschied in der Bcl-2 Menge zwischen U87-MG- 
Zellen mit pEGFP-N1 bzw. pEGFP-N1-Arlts1 auf Proteinebene gezeigt werden (siehe Abbildung 10 B).

A Bcl-2 mRNA

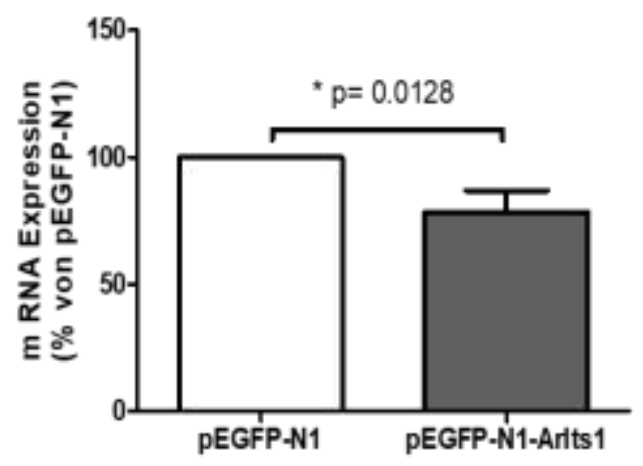

B Bcl-2 Western Blot

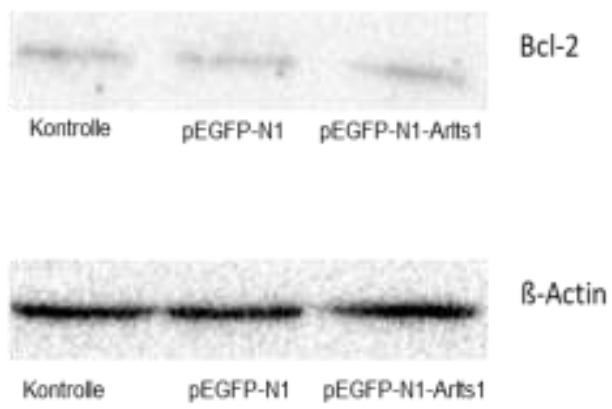

Abb. 10: Expression von Bcl-2; A) Relative mRNA Expression von $B C L-2$ in U87MG-Zellen mit pEGFP-N1 bzw. pEGFP-N1-Arlts1; 24 h nach Transfektion; $n=6$; Student's t-Test B) Western Blot für Bcl-2, U87-MG-Zellen mit pEGFP-N1 bzw. pEGFP-N1-Arlts1, Kontrolle = kein Plasmid transfiziert; 24 h nach Transfektion; $n=4 ; 45 \mu g$ Protein pro Probe

\subsection{Untersuchung der Matrix-Metalloproteasen MMP2 und MMP9}

\subsubsection{Verminderte mRNA Expression von MMP2 und MMP9 in ARLTS1 überex- primierenden U87-MG-Zellen}

Die Überexpression von $B C L-2$ in malignen Gliomen fördert durch die Aktivierung von Matrix-Metalloproteinase 2 und 9 (MMP2/9) Migration und Invasion von Gliomazellen (Wick et al. 1998). Demzufolge ist eine Untersuchung der Matrix-Metalloproteasen in U87-MG-Zellen, die ARLTS1 überexprimieren, angemessen.

Die relative mRNA Expression von $M M P 2$ bzw. 9 wurde mittels Real Time PCR analysiert (siehe 2.2.4). Die relative mRNA Expression von sowohl MMP2 (p <0.0001) als auch von $M M P 9$ ( $\mathrm{p}=0.0374)$ war bei den U87-MG-Zellen mit pEGFP-N1-Arlts1 im Vergleich zur Kontrolle pEGFP-N1 reduziert (siehe Abbildung 11). Die RNA wurde dabei $24 \mathrm{~h}$ nach der Transfektion extrahiert. 

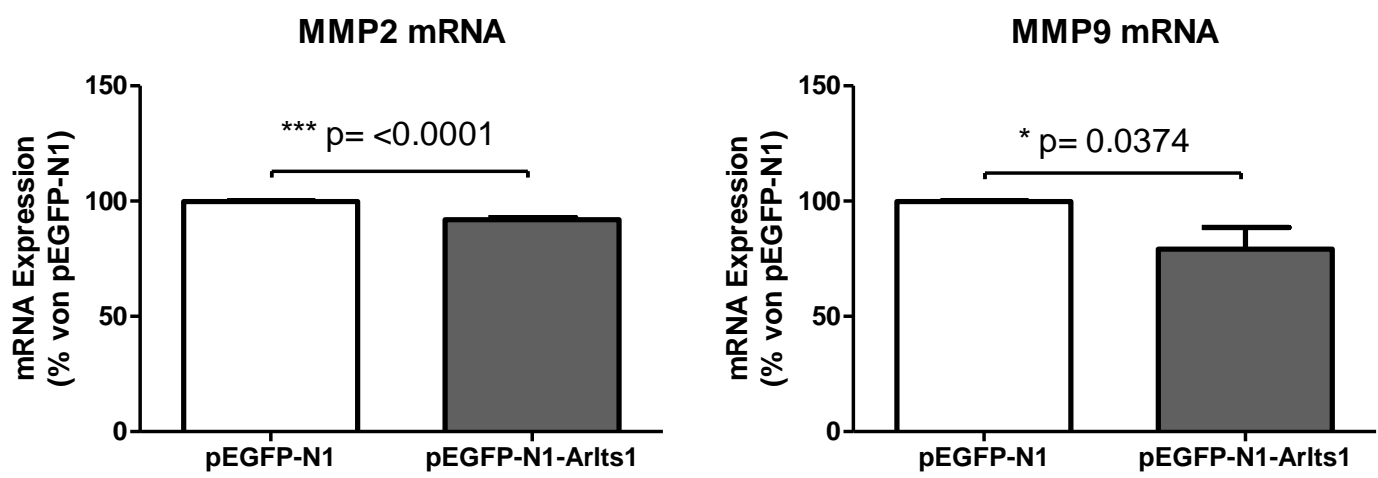

Abb. 11: Real-Time-PCR mit spezifischen Primern für MMP2 und MMP9; signifikante Unterschiede zwischen U87-MG-Zellen mit pEGFP-N1 bzw. pEGFP-N1Arlts1 in mRNA Expression; 24h nach Transfektion; n=6; Student's $t$-Test

\subsubsection{Gelatin-Zymographie zur Überprüfung der aktivierten MMP2 und -9}

Nachdem eine negative Regulation der mRNA Expression von MMP2 und MMP9 in den ARLTS1 überexprimierenden U87-MG-Zellen gezeigt wurde, sollte dieses Ergebnis auch bezüglich der Aktivität dieser Proteinen validiert werden.

Mittels einer Gelatin Zymographie untersuchten wir die Funktionalität der Metalloproteasen 2 und 9. Das Protein wurde $24 \mathrm{~h}$ nach der Transfektion mit pEGFP-N1 bzw. pEGFP-N1-Arlts 1 geerntet (siehe 2.2.3.8). Die MMPs befinden sich sowohl in dem Medium als auch in den Zellen, darum wurden beide Komponenten getrennt aufgereinigt und auf das Gel aufgetragen. In dem SDS-Gel befand sich Gelatine als Substrat. Weiße Banden waren als proteinfrei zu bewerten, dort wurde durch die Gelatinasen (MMP2 bzw. MMP9) das Substrat abgebaut. Eine Färbung mit Coomassie Blau schlägt an dieser Stelle daher nicht mehr an.

In Abbildung 12 wird sichtbar, dass nur die aktive Form von MMP2 (62 kDa) das Gelatin abgebaut hat. Eine Bande auf der Höhe von 82 kDa für das aktive MMP9 ist jedoch nicht zu erkennen. 


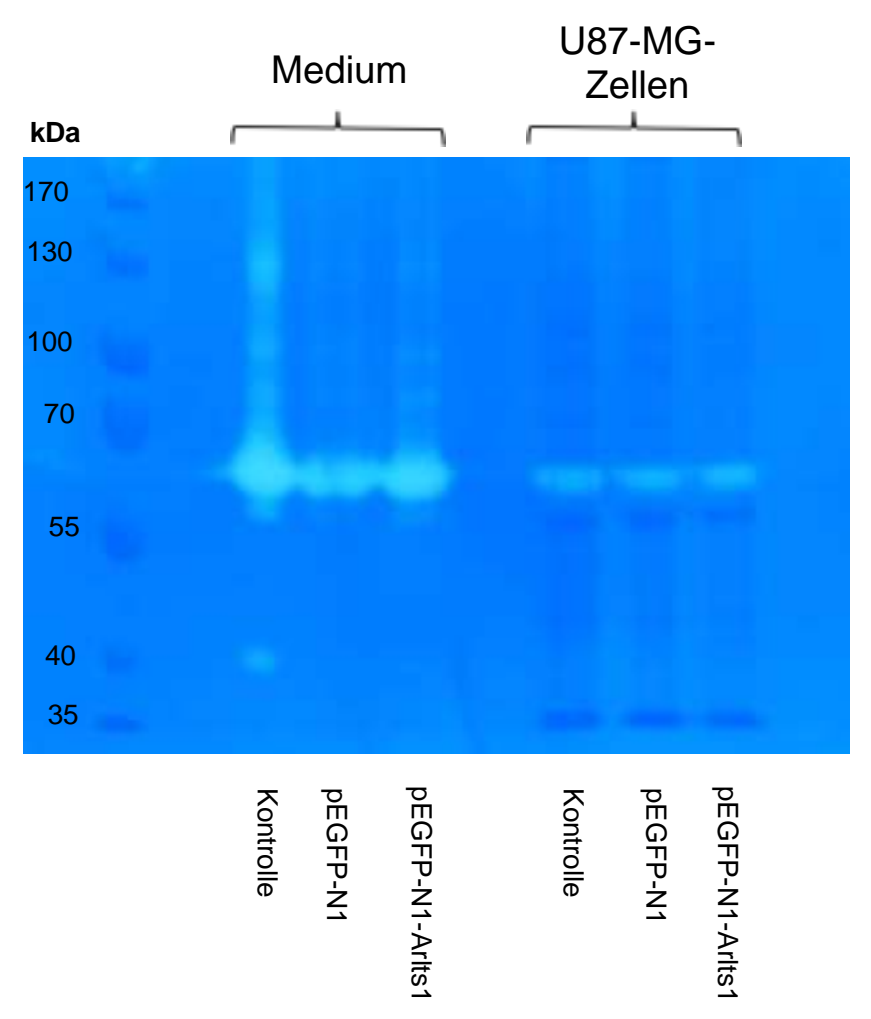

Abb. 12: Gelatin-Zymographie für die Funktionalität von MMP2 und MMP9; weiße Bande auf Höhe von 62 kDa zeigt den Abbau der Gelatine durch aktives MMP2; eine Aktivität von MMP9 ist nicht sichtbar; kein Unterschied des Abbaus zwischen U87-MG-Zellen mit pEGFP-N1 bzw. mit pEGFP-N1-Arlts1; 24 h nach Transfektion; auf das Gel wurden $2 \mu \mathrm{g}$ von dem Medium und $20 \mu \mathrm{g}$ von den Zellen aufgetragen

Ein Unterschied zwischen den U87-MG-Zellen mit pEGFP-N1 bzw. pEGFP-N1-Arlts1 hinsichtlich der Funktion von MMP2 konnte weder im aufgereinigten Medium noch in der Zellsuspension gezeigt werden. Eine Aktivität der Metalloprotease 9 war weder im Medium noch in den U87-MG-Zellen erkennbar. 


\subsection{ARLTS1 hat keinen Einfluss auf das Migrationsverhalten der U87-MG- Zelllinie}

Mit den Plasmiden pEGFP-N1 bzw. pEGFP-N1-Arlts1 transfizierte U87-MG-Zellen wurden mithilfe eines chemotaktischen Gradienten über eine Membran mit Poren und mit Goldelektroden beschichtet, aufgefordert zu migrieren. Vorab wurden die GFP-positiven transfizierten Zellen mittels der FACS-Methode von GFP-negativen Zellen getrennt (siehe 2.2.6.3). Dadurch sollte sichergestellt werden, dass ausschließlich erfolgreich transfizierte Zellen im Migrations-Assay analysiert wurden. Während des Versuches wurde die Veränderung des Widerstandes gemessen. Eine hohe Anzahl an migrierenden Zellen bedeutete eine Zunahme des Widerstandes. Der Migrations-Assay wurde $24 \mathrm{~h}$ nach Transfektion durchgeführt und über einen Zeitraum von 4,5 h dokumentiert. In Abbildung 13 ist das Ergebnis grafisch dargestellt. Die grüne Linie zeigt die Migration der U87-MG-Zellen transfiziert mit pEGFP-N1-Arlts1. Die darunter liegende rote Linie präsentiert die Migration der U87-MG-Zellen, die mit dem Plasmid pEGFP-N1 transfiziert wurden. Der senkrechte Balken zeigt den gemeinsamen Startpunkt der Messung. Da beide Konditionen ausgeprägte Standardabweichungen zeigen, ließ sich zu dem analysierten Zeitpunkt kein Unterschied hinsichtlich der Migration von U87-MG-Zellen mit pEGFP-N1-Arlts1 und der Kontrolle pEGFP-N1 ermitteln.

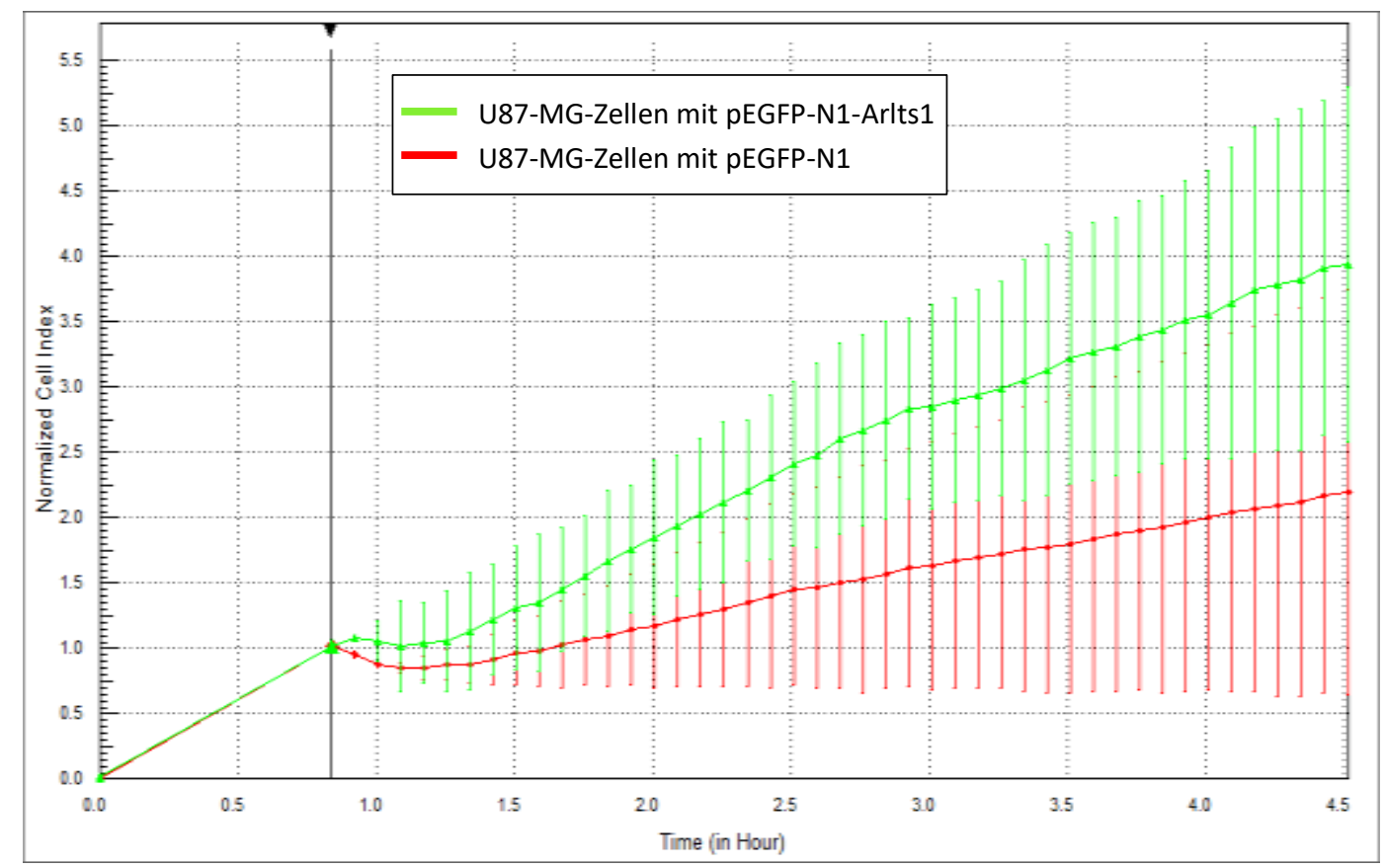

\footnotetext{
Abb. 13: Migrationsassay 24 h nach Transfektion; kein signifikanter Unterschied zwischen U87-MG-Zellen mit pEGFP-N1 bzw. pEGFP-N1-Arlts1
} 


\section{Diskussion}

Die Identifizierung von Tumorsuppressorgenen hat zu einem besseren Verständnis des molekularen Mechanismuses in der Pathogenese von Hirntumoren beigetragen. Arlts1 wurde im Jahr 2005 erstmals als Tumorsuppressorgen beschrieben und gehört zur ArlFamilie (Calin et al. 2005). Weiterhin konnten Untersuchungen bestätigen, dass es eine Funktion in der Regulation der Immunabwehr inne hat (Arya et al. 2018). Der Einfluss von Arlts1 auf apoptotische Prozesse und auf die Krebsentstehung verdeutlichen die Bedeutung der weiterführenden Charakterisierung dieses Proteins. Arlts1 und seine Funktion im Glioblastoma multiforme wurden bis jetzt nicht erforscht. Diese Arbeit widmet sich daher der in vitro Untersuchung der Rolle von Arlts1 im WHO Grad IV GBM. Hierbei kam die Zelllinie U87 MG zur Verwendung, welche den Polymorphismus c. T442C (p. Cys148Arg) in ARLTS1 aufweist. Dieser wird für die Entstehung diverser Tumoren verantwortlich gemacht (Jiang et al. 2017). U87-MG-Zellen wurden mit der wildtyp-Variante von ARLTS1 transfiziert und hinsichtlich Apoptose und Migration untersucht.

\subsection{Der Zusammenhang von Arlts1 und CRABP2}

Wir konnten in vorangegangenen Untersuchungen zeigen, dass die Überexpression von CRABP2 die Apoptose von Glioblastomzellen erhöht (Yao 2016). In diesem Zusammenhang zeigte sich auch, dass U87-MG-Zellen, die CRABP2 überexprimieren, mRNA von ARLTS1 stabilisieren.

CRABP2 ist ein zytosolisches Protein, das für den Transport der Retinsäure (RA) in den Nukleus zuständig ist. Im Nukleus bindet RA schließlich an Rezeptoren (RARs), welche die Transkription von pro-apoptotischen Genen aktivieren (Dong et al. 1999). Somit wurde postuliert, dass CRABP2 die Entstehung von Tumoren verhindert, da der programmierte Zelltod gefördert wird. Für Gliome wurde gezeigt, dass in höhergradigen Tumoren die Expression von CRABP2 vermindert ist (Campos et al. 2011). Allerdings sei erwähnt, dass die Funktion von CRABP2 im GBM kontrovers diskutiert wird. Liu et al. veröffentlichten 2016, dass CRABP2 im Glioblastom hauptsächlich zytosolisch lokalisiert ist und mit einer schlechten Prognose der Patienten korreliert (Liu et al. 2016).

Eine weitere anti-apototische Funktion wird CRABP2 unabhängig von der Retinsäure zugeschrieben. CRABP2 bindet direkt an Humanes Antigen R (HuR, ein RNA bindendes Protein), das bekannt für die Regulation von Trankripten ist (z. B. apoptose proteaseactivating factor-1, Apaf-1). Außerdem soll es auf diesem Weg auch die Transkription von Zellwachstum-hindernden Genen aktivieren (Vreeland et al. 2014). Mittels 
quantitativer Real Time PCR konnten wir bestätigen, dass CRABP2 auch die mRNA von ARLTS1 stabilisiert. Wir konnten zeigen, dass U87-MG-Zellen, welche CRABP2 überexprimieren, eine relativ erhöhte mRNA-Expression von ARLTS1 $24 \mathrm{~h}$ nach Transfektion zeigen. Dieses Ergebnis sollte zusätzlich auf der Ebene von Proteinen bestätigt werden, zum Beispiel mittels eines Western Blots mit einem spezifischen Antikörper gegen Arlts1.

Die Familie der Arl-Proteine ist bekannt dafür, Vesikel und Proteine innerhalb der Zelle zu transportieren (Wennerberg et al. 2005). Lee et al. zeigten im Jahr 2012 eine ProteinProtein-Interaktion von CRABP2 mit Arlts1. Die Autoren stellten die Hypothese auf, dass verminderte ARLTS1 Expression, zum Beispiel durch Hypermethylierung des Promotors, in Tumoren zu einem gestörten Transport der Retinsäure führe und somit die Entstehung von Tumoren begünstige (Lee et al. 2012).

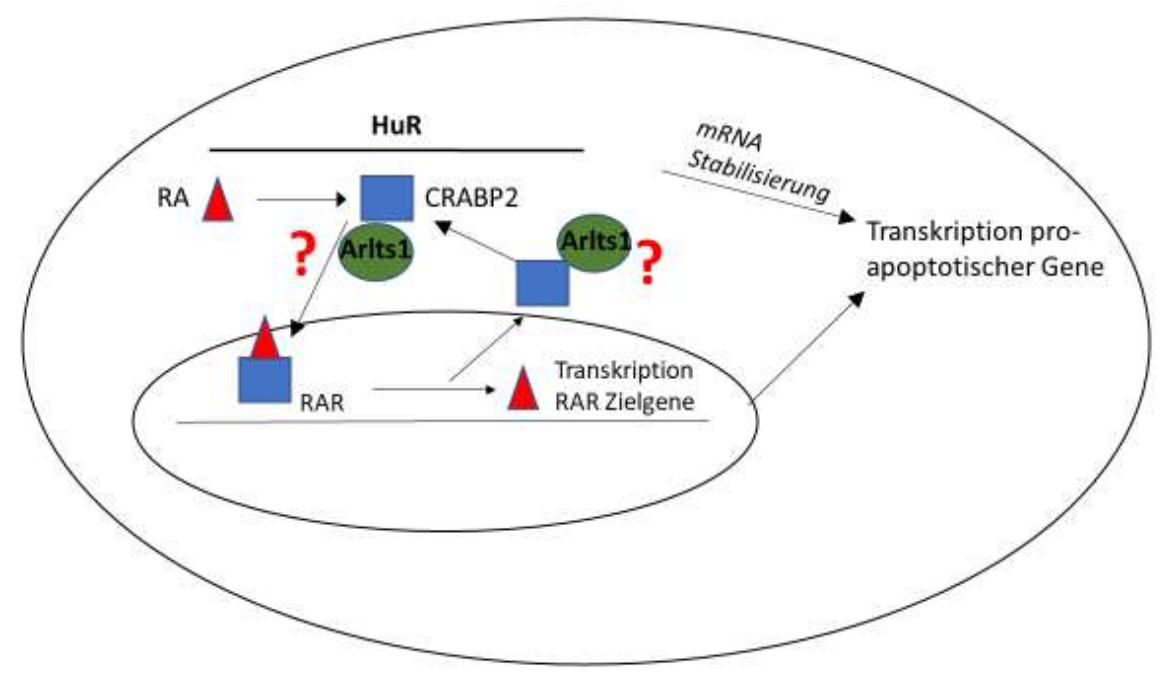

\section{Abb. 14: Hypothese über die Rolle von Arlts1 im Zusammenhang mit CRABP2 in der Zelle (in Anlehnung an Vreeland et al. 2014 und Lee et al. 2012)}

Es lässt sich vermuten, dass Arlts1 am Transport von CRABP2 mitverantwortlich ist. Im Fall einer Runterregulierung von Arlts1 bei der frühen Karzinogenese wäre der Metabolismus der Retinsäure gestört und die Zellen könnten sich ungehindert teilen. Eine Antwort darauf könnte eine fluoreszenz-basierte Ko-Lokalisation von Arlts1 und CRABP2 und Betrachtung mittels konfokaler Mikroskopie geben. Die Überexpression von HuR und der direkte Effekt auf die mRNA von ARLTS1 sollten ebenfalls Gegenstand weiterer Untersuchungen sein. 


\subsection{U87-MG-Zellen transfiziert mit ARLTS1 zeigen keine verstärkte Apoptose}

Eine kontrollierte Proliferation und ein kontrollierter Abbau von Zellen sind entscheidend für ein intaktes Gleichgewicht des Zellwachstums. Eine fehlgesteuerte Apoptose ist ein Grund für die Entstehung von bösartigen Hirntumoren, wie dem Glioblastom. Sogenannte Tumorsuppressorgene sind dafür zuständig, defekte Zellen in den programmierten Zelltod $\mathrm{zu}$ überführen. Eine Inaktivierung dieser Suppressorgene hat die Entstehung von Krebs mitzuverantworten. Die Resistenz gegen Chemotherapeutika in der Therapie von Krebs wird ebenfalls mit einer verminderten Fähigkeit zur Apoptose begründet.

ARLTS1 ist bereits in verschiedenen Tumoren als ein Tumorsuppressorgen beschrieben worden (Jiang et al. 2017). Polymorphismen in dem Gen ARLTS1 wurden erstmals 2005 von Calin et al. in überwiegend familiären, aber auch in sporadisch auftretenden Tumoren beschrieben (Calin et al. 2005).

Es folgten weitere Publikationen, die die Tumorsuppressorfunktion von ARLTS1 bestätigten. Der Polymorphismus c. T442C (p. Cys148Arg) wurde im Mammakarzinom (Frank et al. 2006a; Siltanen et al. 2008), Prostatakarzinom (Siltanen et al. 2011), Ovarialkarzinom (Yang et al. 2009), Malignen Melanom (Frank et al. 2006b) und Kolorektalkarzinom (Castellví-Bel et al. 2007) als an der Tumorgenese beteiligter Faktor erklärt. Der Polymorphismus c. G446A (p. Trp149*) wurde ebenfalls im Kolorektalkarzinom (Frank et al. 2006c), im Ovarialkarzinom (Petrocca et al. 2006) und im bilateralen Mammakarzinom (Frank et al. 2006a) beschrieben. Keine Zusammenhänge wurden bei einem Risiko für die Entstehung von Chronisch lymphatischer Leukämie (Sellick et al. 2006; Ng et al. 2007) und dem Basalzellkarzinom (Li et al. 2007) festgestellt. Die veröffentlichten Ergebnisse widersprechen sich teilweise. Einige der Studien sind aufgrund der geringen Teilnehmerzahl kritisch zu hinterfragen. Eine Meta-Analyse aus dem Jahr 2017 hat die Literatur bezüglich „ARLTS1“ und „Polymorphismen“ genauer untersucht. Das Fazit dieser Analyse ist, dass ausschließlich der Polymorphismus c. T442C (p. Cys148Arg) in ARLTS1 signifikant im Zusammenhang mit der Entstehung von Tumoren steht (Jiang et al. 2017).

In dieser Arbeit wurde die Apoptose von U87-MG-Zellen, welche die wildtyp-Variante von ARLTS1 überexprimieren, untersucht. Es gibt auf der Ebene der mRNA-Expression der Caspasen 3, 7 und 9 keinen Hinweis auf eine erhöhte Apoptose-Aktivität zu dem Zeitpunkt, wenn die Zellen ARLTS1 überexprimieren. 
Mittels Durchflusszytometrie konnten wir ebenfalls zeigen, dass es keinen signifikant erhöhten Zelltod bei U87-MG-Zellen, die ARLTS1 überexprimieren, gibt.

Der programmierte Zelltod ist ein komplexes Zusammenspiel zwischen pro- bzw. antiapoptotischer Proteine. Die Familie der Bcl-2 Proteine nimmt dabei eine entscheidende Rolle ein. Sie beinhaltet unter anderem das gleichnamige Protein Bcl-2, welches eine antiapoptotische Funktion einnimmt und im Rahmen dieser Arbeit untersucht wurde. Die relative mRNA Expression des anti-apoptotischen Gens BCL-2 ist $24 \mathrm{~h}$ nach Transfektion in ARLTS1 überexprimierenden U87-MG-Zellen signifikant verringert. Die Literatur zeigt kontroverse Ergebnisse bezüglich der Expression von $B C L-2$ und der Malignität von Hirntumoren. Nakasu et al. und Ehrmann et al. fanden eine erhöhte Expression von BCL2 in niedrig malignen Tumoren (Nakasu et al. 1994; Ehrmann et al. 1997), während andere Autoren diesen Zusammenhang nicht bestätigen konnten (Schiffer et al. 1996; Newcomb et al. 1997). Eine hohe Expression von $B C L-2$ steht weiterhin für eine erhöhte Resistenz gegenüber einer Chemotherapie im GBM (Weller et al. 1995) und einer vermehrten Migration und Invasion der Tumorzellen (Wick et al. 1998).

Bei der Überprüfung unseres Ergebnisses auf der Ebene der Proteine mittels Western Blot bestätigte sich die negative Regulation von Bcl-2 jedoch nicht. Dies könnte darin begründet sein, dass aufgrund post-transkriptionaler Modifikationen des Proteins Bcl-2 dieses nicht mehr mit seinem Genexpressionslevel korreliert. Eine Dephosphorylierung von Ser87 erleichtert zum Beispiel seinen Ubiquitin-abhängigen Abbau im Proteasom (Breitschopf et al. 2000).

Um tatsächlich Arlts1 als Tumorsuppressor im GBM ausschließen zu können, müssen weitere Zeitpunkte nach der Transfektion untersucht werden. Dafür sollten die U87-MGZellen stabil transfiziert werden, um sicherzustellen, dass auch zu späteren Zeitpunkten GFP und ARLTS1 nach wie vor exprimiert werden.

\subsection{Mögliche inhibitorische Effekte von Arlts1 in der Migration von Glioblastomzellen}

Es wurde gezeigt, dass Bcl-2 exprimierende Gliomazelllinien in vitro eine erhöhte Aktivität der Matrix-Metalloproteasen (MMP) 2 und 9 aufweisen (Wick et al. 1998). Bcl-2 erhöht die Expression von Transforming Growth Factor- $\beta$ (TGF- $\beta$ ) und Furin. Furin ist ein Enzym aus der Gruppe der Serin-Proteasen, die inaktive Proteine in ihre aktive Form überführen können. Dieses Enzym aktiviert die MMPs 2 und 9 im Glioblastom (Wick et 
al. 2004). Furin aktiviert zusätzlich TGF- $\beta$, ein Protein, das ebenfalls die Aktivität der MMPs erhöht (Wick et al. 2001).

MMP 2 und MMP 9 gehören zu den Gelatinasen (A und B) und sind im Glioblastom signifikant erhöht. Es ist beschrieben, dass eine Erhöhung beider MMPs mit der Progression des Glioblastoms korreliert (Sawaya et al. 1996; Forsyth et al. 1999). Patienten mit einem Glioblastom zeigen innerhalb von wenigen Wochen bis Monaten Symptome, wie Kopfschmerzen, motorische Ausfallerscheinungen oder Epilepsien. Binnen kurzer Zeit verschlechtert sich der Zustand der Betroffenen, denn ein schnelles Wachstum ist charakteristisch für das GBM. Für das Wachstum von Glioblastomzellen ist unter anderem die Familie der Metalloproteinasen verantwortlich. Dazu zählen insgesamt 23 Mitglieder. Die MMPs sind für die Degradierung der extrazellulären Matrix (EZM) und Basalmembranen von Zellen zuständig. Damit Tumorzellen sich im Gewebe ausbreiten und metastasieren können, müssen die MMPs die umliegende EZM abbauen können. Eine erhöhte Expression und Aktivität der MMPs steht für die Entwicklung von Krankheiten, wie zum Beispiel Krebs (Nelson et al. 2000).

In dieser Arbeit wurde eine signifikant verminderte Expression der mRNA von MMP 2 und MMP 9 in mit ARLTS1 transfizierten U87-MG-Zellen gezeigt. Die Vermutung, dass Arlts1 die Migration von Gliomazellen reduziert, konnte auf der Ebene der Proteine und mittels eines Migrations-Assays $24 \mathrm{~h}$ nach Transfektion nicht bestätigt werden. Mittels Zymographie-Tests konnten wir jedoch auch die Funktionalität der Metalloproteasen nicht bestätigen. Für MMP 9 konnte in unserer Zymographie sowohl im Medium als auch in den U87-MG-Zellen keine Aktivität gezeigt werden. Es wird in der Literatur kontrovers diskutiert, ob die U87 MG Zelllinie MMP 9 exprimiert (Hagemann et al. 2012). Andere humane Gliomazellinien, wie z.B. GaMG, müssten folglich transfiziert und untersucht werden, da diese Zellen MMP 2 und 9 exprimieren. Ein weiteres Problem bei der Zymographie und einem Migrations-Assay ist, die richtigen Zeitpunkte der Aktivität der MMPs zu finden. Auch hier müssten noch weitere Zeitpunkte nach der Transfektion getestet werden.

Aus der Literatur ist bekannt, dass Bcl-2 die mRNA-Expression von Furin und TGF- $\beta$ erhöht und daraufhin eine vermehrte Aktivität der Metalloproteasen im GBM erfolgt. Um die Idee zu verfolgen, Arlts1 könne die Invasion von Glioblastomzellen herabsenken, könnte man die relative mRNA Expression von Furin und TGF- $\beta$ in den mit ARLTS1 transfizierten U87-MG-Zellen testen. 


\subsection{Kritische Betrachtung und Ausblick der Arbeit}

Die dargestellten Ergebnisse erlauben nur einen ersten Eindruck davon, welche Funktion das Protein Arlts1 im GBM spielt. Eine definitive Festlegung der Aufgabe bei der Entstehung von Gehirntumoren, ist zum jetzigen Zeitpunkt nicht möglich. Unsere Untersuchungen können nicht bestätigen, dass ARLTS1 24 h nach Transfektion ein Tumorsuppressorgen im GBM ist. Dafür müssen weitere Zeitpunkte zur Messung der mRNA Expression der Caspasen hinzugezogen werden. Dies gilt ebenfalls für den Western Blot von Bcl-2, die Zymographie als Nachweis für die Aktivität der MMPs 2 und 9 und den Migrations-Assay. Um auch spätere Zeitpunkte in die Untersuchung mit einzubeziehen, sollten die U87-MG-Zellen stabil transfiziert werden. Nur eine stabile Transfektion sichert eine zeitlich unabhängige Expression von GFP und ARLTS1. Es sollte zusätzlich in Erwägung gezogen werden, die Versuche auf andere Gliomazelllinien zu erweitern. Es ist bekannt, dass über Jahre in vitro kultivierte Zelllinien genetischen und morphologischen Veränderungen unterliegen (Li et al. 2008; Allen et al. 2016).

In mit wildtyp-ARLTS1 transfizierten Ovarialkarzinomzellen wurde eine erhöhte Sensitivität gegenüber Chemotherapeutika in vitro gezeigt (Yang et al. 2011). Auch diese Fragestellung ist bis jetzt nicht für das GBM untersucht und könnte Gegenstand zukünftiger Versuche sein.

Neuste Erkenntnisse konnten erstmals eine Funktion von Arlts1 in Makrophagen ermitteln. Arlts1 reguliert pro-inflammatorische Signalkaskaden in den Immunzellen. Makrophagen mit einer Überexpression von ARLTS1 zeigen eine signifikant vermehrte Produktion pro-inflammatorischer Zytokine, eine vermehrte Aktivität der Makrophagen gegenüber Stimuli wie Salmonella typhimurium und eine Ko-Lokalisation mit phosphoextracellular-signal regulated kinase (ERK) (Arya et al. 2018). Dieses Protein gehört zu der Familie der MAP-Kinasen. Diese Studie wirft die Frage auf, ob die im Gehirn residenten Makrophagen, die Mikroglia, ebenfalls ARLTS1 exprimieren, und das entsprechende Protein eventuell eine Immunantwort auf Glioblastomzellen vermitteln könnte. Somit könnte Arlts1 möglicherweise ein Ziel für eine Immuntherapie bieten.

Ein weiterer sehr interessanter Aspekt ist, ob sich die in der Literatur beschriebenen Polymorphismen von ARLTS1 auch im menschlichen Glioblastoma multiforme häufiger auffinden lassen. Dazu sollte die RNA aus dem Blut von Patienten mit der Diagnose „GBM“ isoliert und genotypisiert werden. 


\section{$5 \quad$ Zusammenfassung}

Trotz multimodaler Therapieansätze bleibt das Glioblastoma multiforme eine Herausforderung für Forschung und Medizin, denn eine 5-Jahres-Überlebensrate von unter 5\% zeigt die schlechteste Prognose aller Hirntumoren. Unter den hirneigenen Tumoren stellt das GBM die größte Entität bei Erwachsenen dar. Das aggressive Wachstum, die Resistenz gegenüber Chemotherapeutika, eine hohe genetische Variabilität und fehlende Biomarker zur Früherkennung sind Gründe, weshalb der Tumor bislang als unheilbar gilt. Aufgrund dessen ist es wichtig, dass biologische Zielstrukturen gesucht werden, die gegenüber der Aggressivität des GBMs widerstandsfähig bleiben und eine Option für eine erfolgreiche Therapie oder eine Früherkennung bieten.

ADP-ribosylation factor like tumor suppressorgen 1 (Arlts) wurde erstmals im Jahr 2005 durch Calin et al. im Zusammenhang mit der Entstehung sporadisch und familiär bedingter Tumoren bekannt. Es folgten verschiedene Publikationen, die bestätigten, dass bestimmte Polymorphismen in dem Gen die Entwicklung von z. B. Bronchial,- Kolorektal,Mamma- oder Prostatakarzinomen begünstigen würden. Bislang ist über Arlts1 nur bekannt, dass es am Transport von Vesikeln beteiligt ist und in Makrophagen pro-immunologische Zyklen aktiviert.

In dieser Arbeit wurde erstmals die Funktion von Arlts1 im Glioblastoma multiforme untersucht.

Ausschlaggebend für diese Fragestellung war folgendes Ergebnis: U87 MG Glioblastomzellen mit einer Überexpression des cellular retinoic acid binding proteins 2 (CRABP2) zeigten $24 \mathrm{~h}$ nach der Transfektion eine Stabilisierung der mRNA von ARLTS1. CRABP2 transportiert nicht nur die Retinsäure vom Zytosol zum Nukleus, sondern ist auch dafür bekannt, diverse RNAs pro-apoptotischer Gene zu stabilisieren.

Daraufhin wurde die U87-MG-Zelllinie kultiviert und mit dem Plasmid pEGFP-N1Arlts1 bzw. der Kontrolle pEGFP-N1 transfiziert und hinsichtlich Apoptose und Migration untersucht. Wir konnten $24 \mathrm{~h}$ nach Transfektion keinen Hinweis auf eine Funktion als Tumorsuppressorgen im GBM finden. Eine Untersuchung mittels quantitativer PCR zeigte keinen Unterschied in der mRNA-Expression der pro-apoptotischen Gene Caspase 3, 7 und 9. Auch auf Proteinebene konnten wir keine vermehrte Apoptose bei Arlts1überexprimierenden Zellen in der Durchflusszytometrie erkennen. Die Marker AnnexinV und Propidiumiodid wurden hierbei zur Detektion des Zelltodes bzw. der Nekrose verwendet. 
Ein signifikanter Unterschied zeigte die mRNA-Expression des anti-apoptotischen Gens BCL-2. U87-MG-Zellen, die ARLTS1 überexprimieren, zeigten eine signifikante Herabregulierung gegenüber der Kontrolle. Obwohl dieses Ergebnis auf Proteinebene mittels Western Blots nicht bestätigt werden konnte - eventuell aufgrund post-transkriptionaler Modifikationen - haben wir nach alternativen Aufgaben von Bcl-2 in Gliomen gesucht. Bcl-2 spielt nicht nur eine entscheidende Rolle im programmierten Zelltod, sondern auch bei der Migration von Glioblastomzellen. Gliome mit einer hohen Expression von Bcl-2 zeigten eine vermehrte Aktivität der Matrix-Metalloproteasen (MMPs), welche die Invasion der Tumorzellen begünstigen. In dieser Arbeit konnten wir eine signifikante Reduktion der mRNA-Expression der MMPs 2 und 9 in U87-MG-Zellen transfiziert mit pEGFP-N1-Arlts1 nachweisen. Zur Überprüfung der Funktionalität der Matrix-Metalloproteasen wählten wir die Zymographie als Nachweismethode. Durch eine Coomassie-Blau-Färbung konnte der Abbau von Gelantin lediglich durch die Matrix-Metalloprotease 2 in einem Agarosegel gezeigt werden. Ein vermehrter Abbau in U87-MG-Zellen mit einer ARLTS1-Überexpression wurde allerdings nicht deutlich. Des Weiteren haben wir die Migration mithilfe einer Variante der Boyden Chamber untersucht. Es konnte kein Unterschied in der Migration zwischen U87-MG-Zellen mit pEGFP-N1-Arlts1 bzw. pEGFP-N1 detektiert werden.

Bei allen oben genannten Versuchen wurde lediglich der Zeitpunkt 24 h nach Transfektion betrachtet. Um eine genaue Aussage über die Funktion von Arlts1 im Glioblastoma multiforme treffen zu können, sollten weitere Zeitpunkte in die Untersuchungen mit einbezogen werden.

Momentan können wir zusammenfassend sagen, dass ARLTS1 kein Tumorsuppressorgen im GBM 24 h nach Transfektion der U87-MG-Zellen darstellt. Eine signifikante Reduktion der mRNA-Expression von Bcl-2, MMP 2 und MMP9 gibt einen ersten Hinweis darauf, dass Arlts1 die Migration von Glioblastomzellen verringern kann.

Die Frage, ob Arlts1 einen potentiellen Biomarker zur Früherkennung oder ein Ziel für eine Therapie bieten kann, sollte in weiterführenden Untersuchungen beantwortet werden. Dadurch könnte die bislang sehr schlechte Überlebensprognose dieser schweren Krankheit verbessert werden. 


\section{$6 \quad$ Literaturverzeichnis}

Allen M, Bjerke M, Edlund H, Nelander S, Westermark B (2016): Origin of the U87MG glioma cell line: Good news and bad news. Sci Transl Med $\underline{8}$, 354re3

Arya SB, Kumar G, Kaur H, Kaur A, Tuli A (2018): ARL11 regulates lipopolysaccharide-stimulated macrophage activation by promoting mitogen-activated protein kinase (MAPK) signaling. J Biol Chem 293, 9892-9909

Bondy ML, Scheurer ME, Malmer B, Barnholtz-Sloan JS, Davis FG, Il'yasova D, Kruchko C, McCarthy BJ, Rajaraman P, Schwartzbaum JA, et al. (2008): Brain Tumor Epidemiology: Consensus from the Brain Tumor Epidemiology Consortium (BTEC). Cancer 113, 1953-1968

Breitschopf K, Haendeler J, Malchow P, Zeiher AM, Dimmeler S (2000): Posttranslational modification of $\mathrm{Bcl}-2$ facilitates its proteasome-dependent degradation: molecular characterization of the involved signaling pathway. Mol Cell Biol $\underline{20}$, 1886-1896

Calin GA, Trapasso F, Shimizu M, Dumitru CD, Yendamuri S, Godwin AK, Ferracin M, Bernardi G, Chatterjee D, Baldassarre G, et al. (2005): Familial cancer associated with a polymorphism in ARLTS1. N Engl J Med 352, 1667-1676

Campos B, Centner F-S, Bermejo JL, Ali R, Dorsch K, Wan F, Felsberg J, Ahmadi R, Grabe N, Reifenberger G, et al. (2011): Aberrant expression of retinoic acid signaling molecules influences patient survival in astrocytic gliomas. Am J Pathol $\underline{178}, 1953-1964$

Castellví-Bel S, Castells A, de Cid R, Muñoz J, Balaguer F, Gonzalo V, Ruiz-Ponte C, Andreu M, Llor X, Jover R, et al. (2007): Association of the ARLTS1 Cys148Arg variant with sporadic and familial colorectal cancer. Carcinogenesis $\underline{28}$, 16871691

Crocetti E, Trama A, Stiller C, Caldarella A, Soffietti R, Jaal J, Weber DC, Ricardi U, Slowinski J, Brandes A (2012): Epidemiology of glial and non-glial brain tumours in Europe. Eur J Cancer $\underline{48}, 1532-1542$

Dong D, Ruuska SE, Levinthal DJ, Noy N (1999): Distinct Roles for Cellular Retinoic Acid-binding Proteins I and II in Regulating Signaling by Retinoic Acid. J Biol Chem 274, 23695-23698

Ehrmann J, Kolár Z, Vojtěsek B, Kala M, Komenda S, Oulton A (1997): Prognostic factors in astrocytomas: relationship of p53, MDM-2, BCL-2 and PCNA immunohistochemical expression to tumor grade and overall patient survival. Neoplasma $\underline{44}, 299-304$

Eoli M, Menghi F, Bruzzone MG, De Simone T, Valletta L, Pollo B, Bissola L, Silvani A, Bianchessi D, D'Incerti L, et al. (2007): Methylation of O6-methylguanine DNA methyltransferase and loss of heterozygosity on $19 q$ and/or $17 p$ are overlapping features of secondary glioblastomas with prolonged survival. Clin Cancer Res $\underline{13}, 2606-2613$ 
Forsyth PA, Wong H, Laing TD, Rewcastle NB, Morris DG, Muzik H, Leco KJ, Johnston RN, Brasher PMA, Sutherland G, Edwards DR (1999): Gelatinase-A (MMP-2), gelatinase-B (MMP-9) and membrane type matrix metalloproteinase-1 (MT1MMP) are involved in different aspects of the pathophysiology of malignant gliomas. Br J Cancer $\underline{79}$, 1828-1835

Frank B, Hemminki K, Meindl A, Wappenschmidt B, Klaes R, Schmutzler RK, Untch M, Bugert P, Bartram CR, Burwinkel B (2006a): Association of the ARLTS1 Cys148Arg variant with familial breast cancer risk. Int J Cancer 118, 2505-2508

Frank B, Meyer P, Boettger MB, Hemminki K, Stapelmann H, Gast A, Schmitt C, Kumar R, Sergi C, Burwinkel B (2006b): ARLTS1 variants and melanoma risk. Int J Cancer $\underline{119}, 1736-1737$

Frank B, Hemminki K, Brenner H, Hoffmeister M, Chang-Claude J, Burwinkel B (2006c): ARLTS1 variants and risk of colorectal cancer. Cancer Lett 244, 172175

Green R, Rogers EJ (2013): Chemical Transformation of E. coli. Methods Enzymol $\underline{529}$, 329-336

Hagemann C, Anacker J, Ernestus R-I, Vince GH (2012): A complete compilation of matrix metalloproteinase expression in human malignant gliomas. World J Clin Oncol $\underline{3}, 67-79$

Hartmann C, Hentschel B, Wick W, Capper D, Felsberg J, Simon M, Westphal M, Schackert G, Meyermann R, Pietsch T, et al. (2010): Patients with IDH1 wild type anaplastic astrocytomas exhibit worse prognosis than IDH1-mutated glioblastomas, and IDH1 mutation status accounts for the unfavorable prognostic effect of higher age: implications for classification of gliomas. Acta Neuropathol $\underline{120}, 707-718$

Hegi ME, Diserens A-C, Gorlia T, Hamou M-F, de Tribolet N, Weller M, Kros JM, Hainfellner JA, Mason W, Mariani L, et al. (2005): MGMT gene silencing and benefit from temozolomide in glioblastoma. N Engl J Med 352, 997-1003

Herman JG (1999): Hypermethylation of tumor suppressor genes in cancer. Semin Cancer Biol $\underline{9}, 359-367$

Iacob G, Dinca E (2009): Current data and strategy in glioblastoma multiforme. J Med Life $\underline{2}, 386-393$

Inskip PD, Tarone RE, Hatch EE, Wilcosky TC, Shapiro WR, Selker RG, Fine HA, Black PM, Loeffler JS, Linet MS (2001): Cellular-telephone use and brain tumors. N Engl J Med 344, 79-86

Jiang Y, Zhao C-Y, Cheng L-C, Xu B, Lv H-Y (2017): ARLTS1 polymorphism is associated with an increased risk of familial cancer: evidence from a meta-analysis. Hered Cancer Clin Pract $\underline{5,8}$

Kleihues P, Ohgaki H (2000): Phenotype vs genotype in the evolution of astrocytic brain tumors. Toxicol Pathol $\underline{28}, 164-170$ 
Kristiansen K, Hagen S, Kollevold T, Torvik A, Holme I, Nesbakken R, Hatlevoll R, Lindgren M, Brun A, Lindgren S, et al. (1981): Combined modality therapy of operated astrocytomas grade III and IV. Confirmation of the value of postoperative irradiation and lack of potentiation of bleomycin on survival time: a prospective multicenter trial of the Scandinavian Glioblastoma Study Group. Cancer $\underline{47}$, $649-652$

Lacroix M, Abi-Said D, Fourney DR, Gokaslan ZL, Shi W, DeMonte F, Lang FF, McCutcheon IE, Hassenbusch SJ, Holland E, et al. (2001): A multivariate analysis of 416 patients with glioblastoma multiforme: prognosis, extent of resection, and survival. J Neurosurg 95, 190-198

Laemmli UK (1970): Cleavage of Structural Proteins during the Assembly of the Head of Bacteriophage T4. Nature 227, 680-685

Lee S, Lee I, Jung Y, McConkey D, Czerniak B (2012): In-Frame cDNA Library Combined with Protein Complementation Assay Identifies ARL11-Binding Partners. PLoS ONE $\underline{7}$, e52290

Li A, Walling J, Kotliarov Y, Center A, Steed ME, Ahn SJ, Rosenblum M, Mikkelsen T, Zenklusen JC, Fine HA (2008): Genomic changes and gene expression profiles reveal that established glioma cell lines are poorly representative of primary human gliomas. Mol Cancer Res $\underline{6}, 21-30$

Li X, Gast A, Rudnai P, Gurzau E, Koppova K, Hemminki K, Kumar R (2007): ARLTS1 polymorphisms and basal cell carcinoma of the skin. Hered Cancer Clin Pract $\underline{5}$, 25-29

Liu R-Z, Li S, Garcia E, Glubrecht DD, Poon HY, Easaw JC, Godbout R (2016): Association between cytoplasmic CRABP2, altered retinoic acid signaling, and poor prognosis in glioblastoma. Glia $\underline{64}, 963-976$

Louis DN, Ohgaki H, Wiestler OD, Cavenee WK, Burger PC, Jouvet A, Scheithauer BW, Kleihues P (2007): The 2007 WHO Classification of Tumours of the Central Nervous System. Acta Neuropathol 114, 97-109

Lowry OH, Rosebrough NJ, Farr AL, Randall RJ (1951): Protein measurement with the Folin phenol reagent. J Biol Chem 193, 265-275

Malmström A, Grønberg BH, Marosi C, Stupp R, Frappaz D, Schultz H, Abacioglu U, Tavelin B, Lhermitte B, Hegi ME, et al. (2012): Temozolomide versus standard 6-week radiotherapy versus hypofractionated radiotherapy in patients older than 60 years with glioblastoma: the Nordic randomised, phase 3 trial. Lancet Oncol $\underline{13}, 916-926$

Masui K, Cloughesy TF, Mischel PS (2012): Review: Molecular pathology in adult highgrade gliomas: from molecular diagnostics to target therapies. Neuropathol Appl Neurobiol $\underline{38}, 271-291$

Nagpal S, Harsh G, Recht L (2011): Bevacizumab Improves Quality of Life in Patients with Recurrent Glioblastoma. Chemother Res Pract 2011, e602812 
Nakamura M, Watanabe T, Yonekawa Y, Kleihues P, Ohgaki H (2001): Promoter methylation of the DNA repair gene MGMT in astrocytomas is frequently associated with G:C --> A:T mutations of the TP53 tumor suppressor gene. Carcinogenesis $\underline{22}, 1715-1719$

Nakasu S, Nakasu Y, Nioka H, Nakajima M, Handa J (1994): bcl-2 protein expression in tumors of the central nervous system. Acta Neuropathol $\underline{88}, 520-526$

Nelson AR, Fingleton B, Rothenberg ML, Matrisian LM (2000): Matrix metalloproteinases: biologic activity and clinical implications. J Clin Oncol $\underline{18}, 1135-1149$

Newcomb EW, Bhalla SK, Parrish CL, Hayes RL, Cohen H, Miller DC (1997): bcl-2 protein expression in astrocytomas in relation to patient survival and p53 gene status. Acta Neuropathol 94, 369-375

Ng D, Toure O, Fontaine L, McMaster ML, Goldin LR, Caporaso N, Toro JR (2007): No association of ARLTS1 polymorphisms and risk for familial chronic lymphocytic leukaemia. Br J Haematol 137, 173-175

Ng WP, Liew BS, Idris Z, Rosman AK (2017): Fluorescence-Guided versus Conventional Surgical Resection of High Grade Glioma: A Single-Centre, 7-Year, Comparative Effectiveness Study. Malays J Med Sci 24, 78-86

Ohgaki H, Kleihues P (2007): Genetic pathways to primary and secondary glioblastoma. Am J Pathol 170, 1445-1453

Ohgaki H, Kleihues P (2009): Genetic alterations and signaling pathways in the evolution of gliomas. Cancer Sci 100, 2235-2241

Ohgaki H, Dessen P, Jourde B, Horstmann S, Nishikawa T, Di Patre P-L, Burkhard C, Schüler D, Probst-Hensch NM, Maiorka PC, et al. (2004): Genetic pathways to glioblastoma: a population-based study. Cancer Res $\underline{64}$, 6892-6899

Ostrom QT, Bauchet L, Davis FG, Deltour I, Fisher JL, Langer CE, Pekmezci M, Schwartzbaum JA, Turner MC, Walsh KM, et al. (2014): The epidemiology of glioma in adults: a "state of the science" review. Neuro Oncol $\underline{16}, 896-913$

Petrocca F, Iliopoulos D, Qin HR, Nicoloso MS, Yendamuri S, Wojcik SE, Shimizu M, Di Leva G, Vecchione A, Trapasso F, et al. (2006): Alterations of the tumor suppressor gene ARLTS1 in ovarian cancer. Cancer Res $\underline{66}$, 10287-10291

Rock K, Mcardle O, Forde P, Dunne M, Fitzpatrick D, O’Neill B, Faul C (2012): A clinical review of treatment outcomes in glioblastoma multiforme - the validation in a non-trial population of the results of a randomised Phase III clinical trial: has a more radical approach improved survival? Br J Radiol 모, e729-e733

Sanger F, Coulson AR (1975): A rapid method for determining sequences in DNA by primed synthesis with DNA polymerase. J Mol Biol 94, 441-448

Sawaya RE, Yamamoto M, Gokaslan ZL, Wang SW, Mohanam S, Fuller GN, McCutcheon IE, Stetler-Stevenson WG, Nicolson GL, Rao JS (1996): Expression and localization of $72 \mathrm{kDa}$ type IV collagenase (MMP-2) in human malignant gliomas in vivo. Clin Exp Metastasis $\underline{14}, 35-42$ 
Schiff D, Lee EQ, Nayak L, Norden AD, Reardon DA, Wen PY (2015): Medical management of brain tumors and the sequelae of treatment. Neuro Oncol $\underline{17}, 488-$ 504

Schiffer D, Cavalla P, Migheli A, Giordana MT, Chiadò-Piat L (1996): Bcl-2 distribution in neuroepithelial tumors: an immunohistochemical study. J Neurooncol 27 , 101109

Sellick GS, Catovsky D, Houlston RS (2006): Relationship between ARLTS1 polymorphisms and risk of chronic lymphocytic leukemia. Leuk Res $\underline{30}, 1573-1576$

Siltanen S, Syrjäkoski K, Fagerholm R, Ikonen T, Lipman P, Mallott J, Holli K, Tammela TL, Järvinen HJ, Mecklin J-P, et al. (2008): ARLTS1 germline variants and the risk for breast, prostate, and colorectal cancer. Eur J Hum Genet 16, 983-991

Siltanen S, Wahlfors T, Schindler M, Saramäki OR, Mpindi JP, Latonen L, Vessella RL, Tammela TLJ, Kallioniemi O, Visakorpi T, Schleutker J (2011): Contribution of ARLTS1 Cys148Arg (T442C) Variant with Prostate Cancer Risk and ARLTS1 Function in Prostate Cancer Cells. PLoS ONE $\underline{6}$, e26595

Siltanen S, Fischer D, Rantapero T, Laitinen V, Mpindi JP, Kallioniemi O, Wahlfors T, Schleutker J (2013): ARLTS1 and Prostate Cancer Risk - Analysis of Expression and Regulation. PLOS ONE $\underline{8}$, e72040

Sindelárová L, Michalová K, Zemanová Z, Ransdorfová S, Brezinová J, Peková S, Schwarz J, Karban J, Cmunt E (2005): Incidence of chromosomal anomalies detected with FISH and their clinical correlations in B-chronic lymphocytic leukemia. Cancer Genet Cytogenet 160, 27-34

Smoll NR, Schaller K, Gautschi OP (2013): Long-term survival of patients with glioblastoma multiforme (GBM). J Clin Neurosci 20, 670-675

Stummer W, Pichlmeier U, Meinel T, Wiestler OD, Zanella F, Reulen H-J (2006): Fluorescence-guided surgery with 5-aminolevulinic acid for resection of malignant glioma: a randomised controlled multicentre phase III trial. Lancet Oncol ㄱ, 392401

Stupp R, Hegi ME, Mason WP, van den Bent MJ, Taphoorn MJB, Janzer RC, Ludwin SK, Allgeier A, Fisher B, Belanger K, et al. (2009): Effects of radiotherapy with concomitant and adjuvant temozolomide versus radiotherapy alone on survival in glioblastoma in a randomised phase III study: 5-year analysis of the EORTCNCIC trial. Lancet Oncol 10, 459-466

Tran B, Rosenthal MA (2010): Survival comparison between glioblastoma multiforme and other incurable cancers. J Clin Neurosci 17, 417-421

Vreeland AC, Yu S, Levi L, de Barros Rossetto D, Noy N (2014): Transcript Stabilization by the RNA-Binding Protein HuR Is Regulated by Cellular Retinoic Acid-Binding Protein 2. Mol Cell Biol 34, 2135-2146

Weller M, Malipiero U, Aguzzi A, Reed JC, Fontana A (1995): Protooncogene bcl-2 gene transfer abrogates Fas/APO-1 antibody-mediated apoptosis of human malignant 
glioma cells and confers resistance to chemotherapeutic drugs and therapeutic irradiation. J Clin Invest 95, 2633-2643

Wennerberg K, Rossman KL, Der CJ (2005): The Ras superfamily at a glance. J Cell Sci $\underline{118}, 843-846$

Wick W, Wagner S, Kerkau S, Dichgans J, Tonn JC, Weller M (1998): BCL-2 promotes migration and invasiveness of human glioma cells. FEBS Lett $\underline{440}$, 419-424

Wick W, Platten M, Weller M (2001): Glioma cell invasion: regulation of metalloproteinase activity by TGF-beta. J Neurooncol $\underline{53}, 177-185$

Wick W, Wild-Bode C, Frank B, Weller M (2004): BCL-2-induced glioma cell invasiveness depends on furin-like proteases. J Neurochem $\underline{91}$, 1275-1283

Yan H, Parsons DW, Jin G, McLendon R, Rasheed BA, Yuan W, Kos I, Batinic-Haberle I, Jones S, Riggins GJ, et al. (2009): IDH1 and IDH2 mutations in gliomas. N Engl J Med 360, 765-773

Yang XY, Yu H, Xi MR, Yang KX, Pan XL, Hu M, Peng ZL (2009): Association of the ARLTS1 variants with familial ovarian cancer risk in China. Int J Gynecol Cancer $\underline{19}, 585-590$

Yang XY, Yu H, Peng ZL (2011): Involvement of ARLTS1 in chemotherapy and apoptosis in ovarian cancer cell line. Arch Gynecol Obstet 284, 1241-1246

Yao L: HDAC inhibitor valproic acid increases CRABP2 expression and in combination with retinoic acid synergistically inhibits proliferation in glioblastoma cells. Med. Diss. Göttingen 2016

Yendamuri S, Trapasso F, Ferracin M, Cesari R, Sevignani C, Shimizu M, Rattan S, Kuroki T, Dumon KR, Bullrich F, et al. (2007): Tumor suppressor functions of ARLTS1 in lung cancers. Cancer Res $\underline{67}, 7738-7745$

Young RM, Jamshidi A, Davis G, Sherman JH (2015): Current trends in the surgical management and treatment of adult glioblastoma. Ann Transl Med $\underline{3}, 121$ 


\section{Publikationen/ Fachvorträge}

Hammer C, Stepniak B, Schneider A, Papiol S, Tantra M, Begemann M, Sirén A-L, Pardo LA, Sperling S, Mohd Jofrry S, et al. (2014): Neuropsychiatric disease relevance of circulating anti-NMDA receptor autoantibodies depends on blood-brain barrier integrity. Mol Psychiatry $\underline{19}, 1143-1149$

Ostmeier K: Die Rolle von ARLTS1 im Glioblastoma multiforme, Kongress der „Deutschen Gesellschaft für Neurochirurgie“, Münster, 4. Juni 2018

Wüstefeld L, Winkler D, Janc OA, Hassouna I, Ronnenberg A, Ostmeier K, Müller M, Brose N, Ehrenreich H, Wojcik SM (2016): Selective expression of a constitutively active erythropoietin receptor in GABAergic neurons alters hippocampal network properties without affecting cognition. J Neurochem $\underline{136}$, 698-705 


\section{Danksagung}

Mein besonderer Dank gilt meinem Doktorvater Herrn Prof. Dr. med. Veit Rohde, meiner Ko-Betreuerin Frau Prof. Dr. med. Heide Siggelkow und meiner Betreuerin Frau Dr. rer. nat. Milena Ninkovic für die ausgezeichnete Betreuung und Unterstützung dieser wissenschaftlichen Arbeit. An dieser Stelle möchte ich besonders Swetlana Sperling für die stets geduldige und kompetente Hilfe im Labor und für unsere Freundschaft danken. 